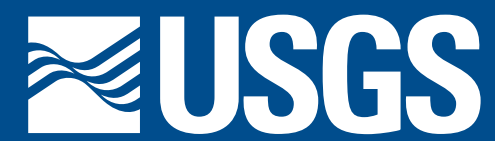

science for a changing world

Prepared in cooperation with the City of Wichita, Kansas

\title{
Water Quality and Relation to Taste-and-Odor Compounds in the North Fork Ninnescah River and Cheney Reservoir, South-Central Kansas, 1997-2003
}

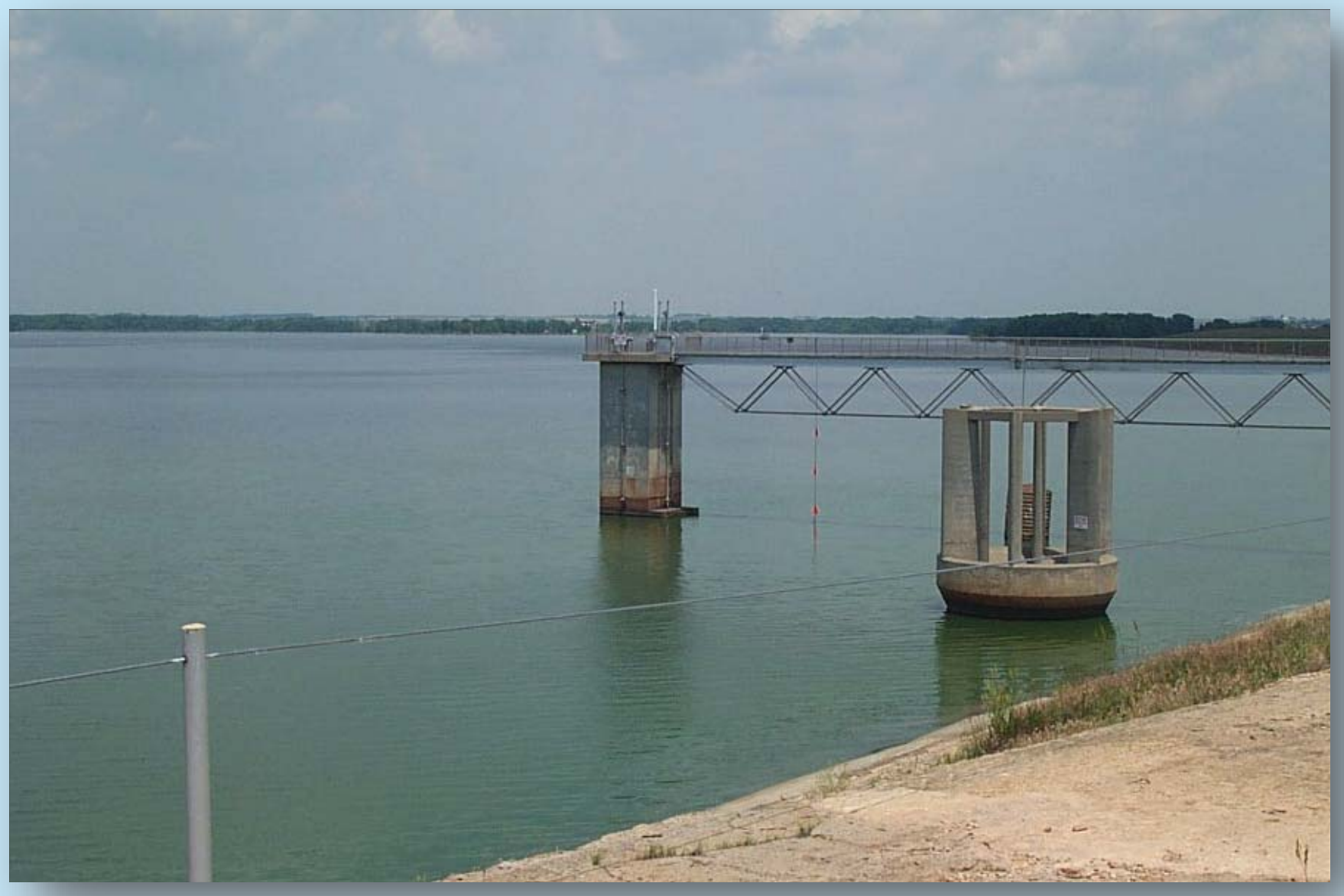

Scientific Investigations Report 2006-5095 


\section{Water Quality and Relation to Taste-and- Odor Compounds in the North Fork Ninnescah River and Cheney Reservoir, South-Central Kansas, 1997-2003}

By Victoria G. Christensen, Jennifer L. Graham, Chad R. Milligan, Larry M. Pope, and Andrew C. Ziegler

Prepared in cooperation with the City of Wichita, Kansas

Scientific Investigations Report 2006-5095 


\title{
U.S. Department of the Interior P. Lynn Scarlett, Acting Secretary
}

\author{
U.S. Geological Survey \\ P. Patrick Leahy, Acting Director
}

\section{U.S. Geological Survey, Reston, Virginia: 2006}

For sale by U.S. Geological Survey, Information Services

Box 25286, Denver Federal Center

Denver, CO 80225

For more information about the USGS and its products:

Telephone: 1-888-ASK-USGS

World Wide Web: http://www.usgs.gov/

Any use of trade, product, or firm names in this publication is for descriptive purposes only and does not imply endorsement by the U.S. Government.

Although this report is in the public domain, permission must be secured from the individual copyright owners to reproduce any copyrighted materials contained within this report.

Suggested citation:

Christensen, V.G., Graham, J.L., Milligan, C.R., Pope, L.M., and Ziegler, A.C., 2006, Water quality and relation to tasteand-odor compounds in the North Fork Ninnescah River and Cheney Reservoir, south-central Kansas, 1997-2003: U.S. Geological Survey Scientific Investigations Report 2006-5095, 43 p.

Front cover: Water intake at Cheney Reservoir, June 2003 (photograph courtesy of Kelly Kelsey, Kansas Department of Health and Environment).

Back cover: (Top) North Fork Ninnescah River, spring 2006 (photograph taken by J.L. Graham, USGS, Lawrence, KS). (Bottom) USGS monitoring station on North Fork Ninnescah River above Cheney Reservoir, March 2006, (photograph taken by J.L. Graham, USGS, Lawrence, KS). 


\section{Contents}

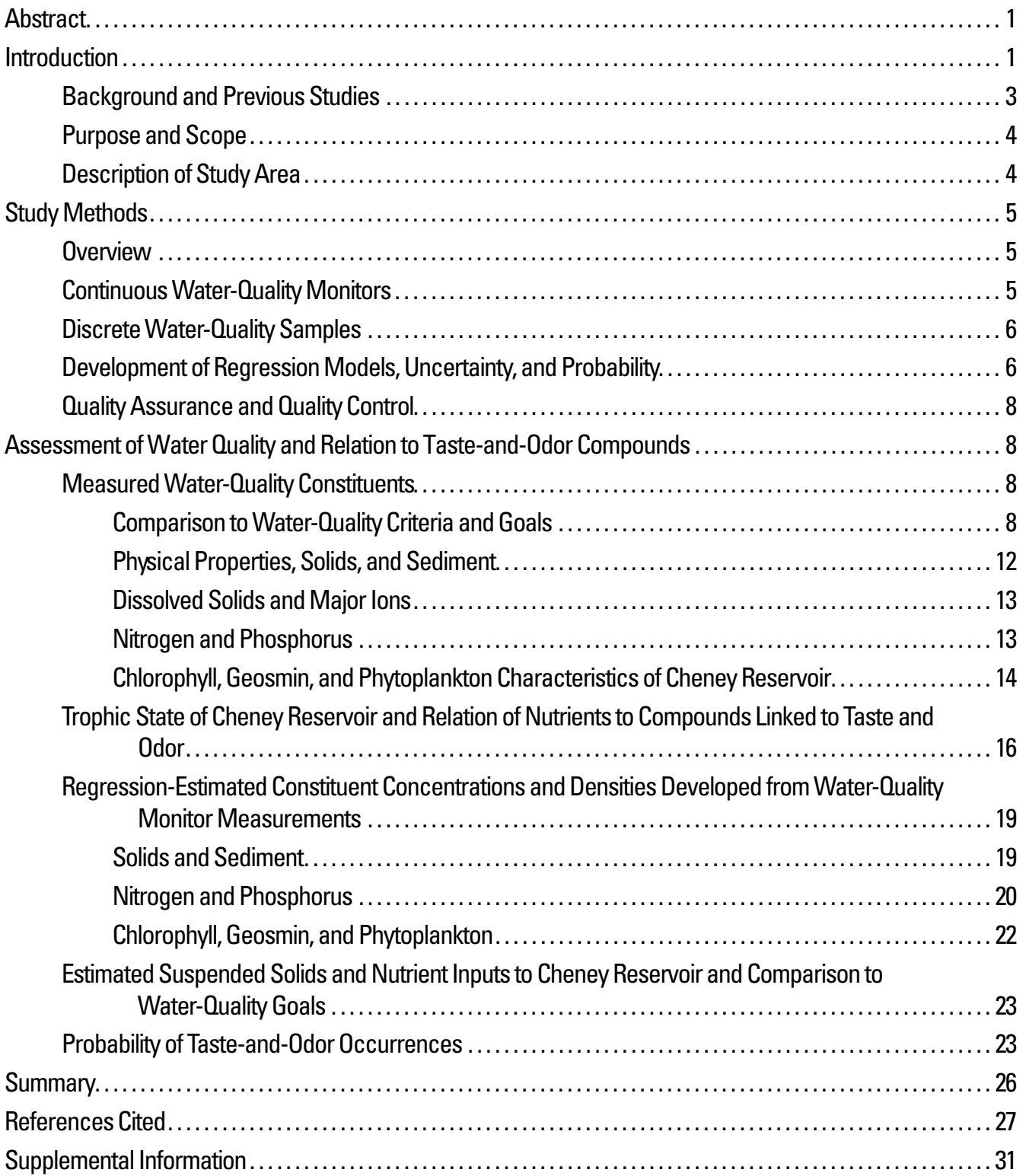

\section{Figures}

1. Map showing location of Cheney Reservoir watershed and streamflow-gaging/water-quality sampling sites, south-central Kansas.

2-8. Graphs showing:

2. Comparison of laboratory-analyzed chlorophyll-a concentration and in-situ fluorescence in

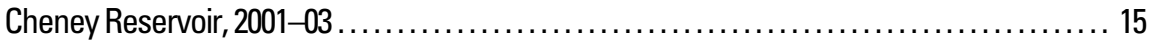

3. Percentage of total phytoplankton biovolume and geosmin concentration in Cheney Reservoir, 2001-03. 
4. Relation of chlorophyll- $a$ to total Kjeldahl nitrogen, total phosphorus, and geosmin concentrations, and Anabaena biovolume in water from Cheney Reservoir, 2001-03 18

5. Relation of turbidity to total Kjeldahl nitrogen, total phosphorus, chlorophyll-a, and geosmin concentrations, and Anabaena biovolume in water from Cheney Reservoir, 2001-03...... 19

6. Comparison of Anabaena biovolume to total Kjeldahl nitrogen, total phosphorus, geosmin, and microcystin concentrations in water from Cheney Reservoir, 2001-03.

7. Comparison of streamflow and mean stream-water-quality goals to regression-estimated mean daily total suspended solids and total phosphorus concentrations in water from North Fork Ninnescah River above Cheney Reservoir, 2001-03.

8. Comparison of measured and regression-estimated geosmin concentrations in water samples from Cheney Reservoir, 2003, and probability of exceeding the human detection level of 0.01 microgram per liter.

\section{Tables}

1. Mean stream-water-quality goals established by Cheney Reservoir Task Force for total suspended solids, dissolved nitrate, and total phosphorus in streams of Cheney Reservoir watershed, southcentral Kansas, during base-flow, runoff, and long-term streamflow conditions. ...

2. Streamflow-gaging/water-quality sampling sites in Cheney Reservoir watershed, south-central Kansas.

3. Annual water budgets for Cheney Reservoir, south-central Kansas, 1997-2003 ..................

4. Statistical summary of streamflow and water-quality data collected from North Fork Ninnescah River above Cheney Reservoir and Cheney Reservoir, south-central Kansas, 1997-2003 . ...............9

5. Regression equations showing relation between suspended-sediment concentration and total suspended solids, nutrients, and bacteria in the North Fork Ninnescah River above Cheney Reservoir,

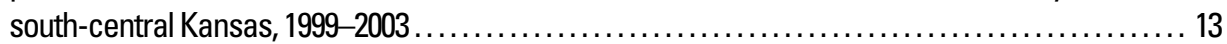

6. Mean trophic state index values for Cheney Reservoir, south-central Kansas, 1999-2003 . ........ 17

7. Regression models used to estimate concentrations or densities of selected physical, chemical, and biological properties of water in North Fork Ninnescah River and Cheney Reservoir, south-central

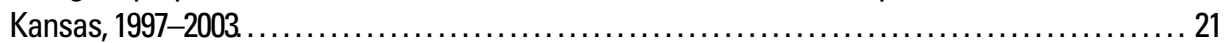

8. Phytoplankton taxa, biovolume, and percentage of total biovolume, Cheney Reservoir, south-central Kansas, 2001-03. 


\section{Conversion Factors, Abbreviations, and Datum}

\begin{tabular}{lcl}
\hline Multiply & \multicolumn{1}{c}{ By } & To obtain \\
\hline acre & 0.004047 & square kilometer $\left(\mathrm{km}^{2}\right)$ \\
acre-foot (acre-ft) & 1,233 & cubic meter $\left(\mathrm{m}^{3}\right)$ \\
cubic foot per second $\left(\mathrm{ft}^{3} / \mathrm{s}\right)$ & 0.02832 & cubic meter per second $\left(\mathrm{m}^{3} / \mathrm{s}\right)$ \\
cubic micrometer $\left(\mu \mathrm{m}^{3}\right)$ & $6.102 \times 10^{-14}$ & cubic inch $\left(\mathrm{in}^{3}\right)$ \\
cubic micrometer per milliliter $\left(\mu \mathrm{m}^{3} / \mathrm{mL}\right)$ & $1.805 \times 10^{-12}$ & cubic inch per ounce $\left(\mathrm{in}^{3} / \mathrm{oz}\right)$ \\
foot $(\mathrm{ft})$ & 0.3048 & meter $(\mathrm{m})$ \\
gallon $(\mathrm{gal})$ & 3.785 & liter $(\mathrm{L})$ \\
inch (in.) & 2.54 & centimeter $(\mathrm{cm})$ \\
microgram per liter $(\mu \mathrm{g} / \mathrm{L})$ & 1.0 & part per billion $(\mathrm{ppb})$ \\
mile (mi) & 1.609 & kilometer $(\mathrm{km})$ \\
mile per hour $(\mathrm{mi} / \mathrm{h})$ & 1.609 & kilometer per hour $(\mathrm{km} / \mathrm{h})$ \\
milligram per day $(\mathrm{mg} / \mathrm{d})$ & 0.0000353 & ounce per day $(\mathrm{oz} / \mathrm{d})$ \\
milligram per kilogram $(\mathrm{mg} / \mathrm{kg})$ & 0.000016 & ounce per pound $(\mathrm{oz} / \mathrm{lb})$ \\
milligram per liter $(\mathrm{mg} / \mathrm{L})$ & 1.0 & part per million $(\mathrm{ppm})$ \\
milliliter $(\mathrm{mL})$ & 0.0338 & ounce, fluid $(\mathrm{oz})$ \\
nanogram per liter $(\mathrm{ng} / \mathrm{L})$ & 1.0 & part per trillion $(\mathrm{ppt})$ \\
nanometer $(\mathrm{nm})$ & $3.937 \times 10^{-8}$ & inch (in.) \\
square mile $\left(\mathrm{mi}{ }^{2}\right)$ & 2.590 & square kilometer $\left(\mathrm{km}{ }^{2}\right)$ \\
\hline
\end{tabular}

Temperature in degrees Fahrenheit $\left({ }^{\circ} \mathrm{F}\right)$ may be converted to degrees Celsius $\left({ }^{\circ} \mathrm{C}\right)$ as follows:

$$
{ }^{\circ} \mathrm{C}=\left({ }^{\circ} \mathrm{F}-32\right) / 1.8 \text {. }
$$

Temperature in degrees Celsius $\left({ }^{\circ} \mathrm{C}\right)$ may be converted to degrees Fahrenheit $\left({ }^{\circ} \mathrm{F}\right)$ as follows:

$$
{ }^{\circ} \mathrm{F}=\left(1.8 \mathrm{x}{ }^{\circ} \mathrm{C}\right)+32
$$

Specific conductance is given in microsiemens per centimeter at 25 degrees Celsius $(\mu \mathrm{S} / \mathrm{cm}$ at $\left.25^{\circ} \mathrm{C}\right)$.

Horizontal coordinate information is referenced to the North American Datum of 1983 (NAD 83). 


\title{
Water Quality and Relation to Taste-and-Odor Compounds in the North Fork Ninnescah River and Cheney Reservoir, South-Central Kansas, 1997-2003
}

\author{
By Victoria G. Christensen, Jennifer L. Graham, Chad R. Milligan, Larry M. Pope, and Andrew C. Ziegler
}

\section{Abstract}

Cheney Reservoir, the primary water supply for the city of Wichita in south-central Kansas, and its main source of inflow, the North Fork Ninnescah River, were sampled between 1997 and 2003 for sediment, nutrients, and the taste-and-odorcausing compounds geosmin and 2-methylisoborneol (MIB). It is believed that objectionable tastes and odors in Cheney Reservoir result from cyanobacteria (blue-green algae), and there is concern with proliferation of algal growth. Both nutrients and suspended solids affect algal growth and may be a concern for taste-and-odor issues. The transport of nutrients and suspended solids from the North Fork Ninnescah River to Cheney Reservoir was monitored as part of an effort to understand and thereby mitigate algal proliferation. The regression-estimated concentrations of total phosphorus in water entering the reservoir from the North Fork Ninnescah River during 2001-03 exceeded the base-flow, runoff, and long-term goals established by the Cheney Reservoir Task Force. Total suspended-solids concentrations in water from the North Fork Ninnescah River during 2001-03 generally exceeded long-term goals only during periods of runoff.

Water samples from Cheney Reservoir were analyzed for geosmin and MIB, the two most common taste-and-odor causing compounds produced by cyanobacteria. MIB was rarely detected in samples, indicating that geosmin is likely the primary source of objectionable tastes and odors. Anabaena, a cyanobacterial genera often linked to taste-and-odor occurrences, was not statistically related to geosmin in Cheney Reservoir, which indicates that Anabaena abundance is not linearly related to geosmin concentration or that other cyanobacteria are producing geosmin.

Regression models were developed between geosmin and the physical property measurements continuously recorded by water-quality monitors at each site. The geosmin regression model was applied to water-quality monitor measurements, providing a continuous estimate of geosmin for 2003 . The city of Wichita will be able to use this type of analysis to determine the probability of when concentrations of geosmin are likely to be at or above the human detection level of 0.01 microgram per liter.

\section{Introduction}

Cheney Reservoir (fig. 1) was constructed by the Bureau of Reclamation (BOR), U.S. Department of the Interior, between 1962 and 1965 to provide downstream flood control, wildlife habitat, recreational opportunities, and a reliable municipal water supply for the city of Wichita, Kansas. The city of Wichita acquires about 70 percent of its daily water supply from Cheney Reservoir (Kansas Department of Agriculture, Division of Water Resources, written commun., 2005) and provides this water to about 350,000 residents in the Wichita area. Objectionable tastes and odors have been a concern in the finished drinking water from Cheney Reservoir since 1990.

Taste-and-odor compounds cause unpalatable drinking water, resulting in increased treatment costs, and are a concern throughout the United States. Largely produced by algae, many taste-and-odor compounds are considered algal by-products with no known cellular function. The production of tasteand-odor compounds varies both within and among algal species; some actively excrete the compounds into the environment, whereas others maintain them intracellularly, releasing the compounds only after cell lysis and death. Geosmin and 2-methylisoborneol (MIB), produced by blue-green algae (cyanobacteria) and actinomycetes bacteria, cause earthy and musty tastes and odors and are frequently responsible for customer complaints about objectionable drinking water (Mallevialle and Suffet, 1987; Rashash and others, 1996; Watson, 2003). Taste-and-odor problems in Cheney Reservoir have been described as earthy and musty, and are believed to be associated with geosmin and MIB produced by cyanobacteria (Smith and others, 2002; City of Wichita, 2005).

Taste-and-odor occurrences also are a concern because they may be indicative of the presence of potentially toxic algae. Many taste-and-odor producing cyanobacteria, including Anabaena, Microcystis, and Oscillatoria, also have the potential to produce potent toxins (called cyanotoxins) that may cause illness after exposure through drinking water or recreational activities (Chorus and Bartram, 1999; Watson, 2003). A national water-supply study done in cooperation with the American Water Works Association Research Foundation (AWWARF) by Carmichael (2001) analyzed samples of water 


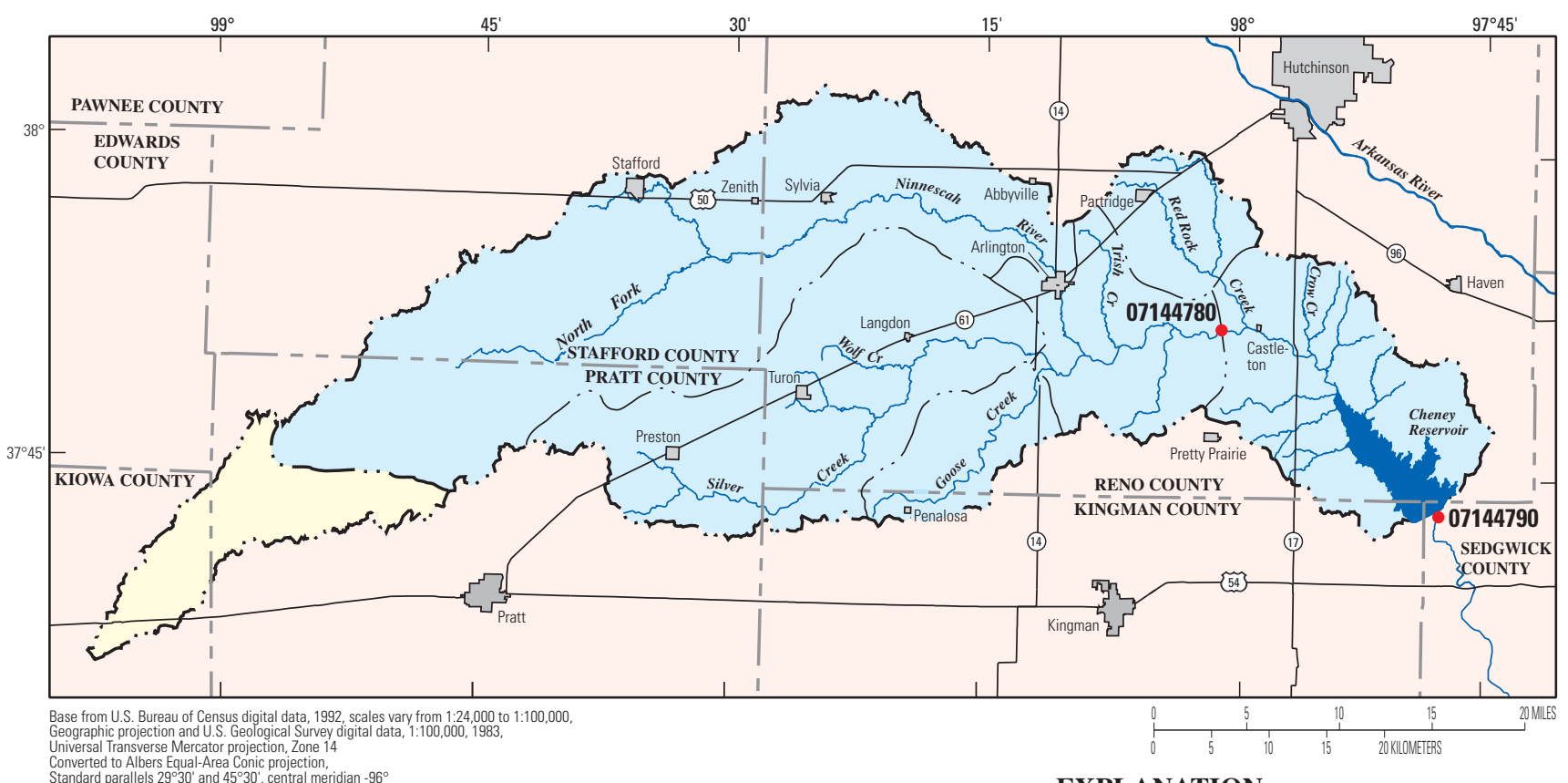

EXPLANATION

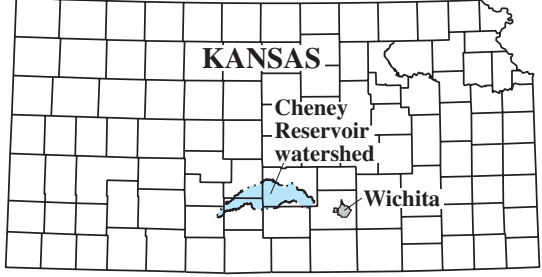

Index map

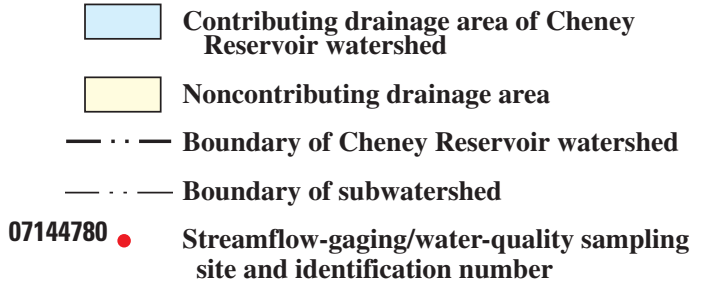

site and identification number

Figure 1. Location of Cheney Reservoir watershed and streamflow-gaging/water-quality sampling sites, south-central Kansas.

and algae for microcystin, a cyanobacterial hepatoxin, and the taste-and-odor compounds geosmin and MIB. Samples of the raw and finished drinking water were collected by 45 drinkingwater treatment plants in Canada and the United States. Of the 677 samples collected, 80 percent had detectable concentrations of microcystin; however, only two treatment plants had finished water concentrations exceeding the World Health Organization drinking-water guideline of $1 \mu \mathrm{g} / \mathrm{L}$. Of the 243 samples analyzed for taste-and-odor compounds, 75 percent had detectable concentrations. Of the samples that tested positive for taste and odor, 82 percent also had microcystin present. Carmichael (2001) concludes that, if source water contains Anabaena, Cylindrospermopsis, Microcystis, or Oscillitoria, water utilities should consider that microcystin also is present.

Attempts to solve taste-and-odor problems within a treatment plant can be costly and seldom succeed completely (Walker and others, 1989; Blain, 2001); therefore, identification of the factors driving algal growth is key to mitigating taste-and-odor problems. Environmental factors such as light limitation, nutrient enrichment, and low nitrogen:phosphorus ratios favor cyanobacterial dominance thereby increasing the risk of taste-and-odor episodes caused by geosmin and MIB. The transport of suspended solids, sediment, nitrate, total phosphorus, and other constituents relevant to drinking-water quality into Cheney Reservoir has been studied in an effort to understand in-lake processes that can be used to maintain a quality water supply and to mitigate cyanobacterial proliferation (blooms). Monitoring identifies key factors that may affect cyanobacterial proliferation; on the basis of the factors identified, plans can be developed to mitigate loads. Bestmanagement practices (BMPs) have been implemented in the Cheney Reservoir watershed to limit the transport of physical, chemical, and biological water-quality constituents into the reservoir (Blain, 2001).

Maintaining acceptable surface-water quality in the Cheney Reservoir watershed is important not only because the reservoir is used as a municipal water supply but also because it is a recreational resource. Additionally, surface-water quality needs to be maintained to prevent detrimental effects on aquatic organisms, disruption of fish populations, and interference with the natural life cycles of plants and animals relying on surface water for growth and reproduction. 


\section{Background and Previous Studies}

In direct response to 1990-91 taste-and-odor occurrences, a task force was formed in 1992 to study and prepare a plan to identify and mitigate potential sources of stream contamination in the Cheney Reservoir watershed. The Cheney Reservoir Task Force, consisting of members of the Reno and Sedgwick County Conservation Districts, Reno County Health Department, Wichita Water and Sewer Department, and other local, State and Federal agencies, was established to study contamination problems, to develop stream-water-quality goals, and, with the assistance of cooperating agencies, to implement and maintain BMPs throughout the Cheney Reservoir watershed (Cheney Reservoir Task Force Committee, written commun., 1996). BMPs in the Cheney Reservoir watershed include but are not limited to field terracing, stubble mulch, grassed waterways, and efficient fertilizer application.

The Cheney Reservoir Task Force prepared a waterquality plan in part to mitigate the transport of suspended solids, nutrients, pesticides, and other agriculturally linked chemicals into the reservoir. A reduction in the transport of suspended solids and nutrients into Cheney Reservoir would reduce the potential for excessive sedimentation that could decrease the useful life of the reservoir and the potential for reservoir eutrophication (nutrient enrichment). The reduction in transport of solids and nutrients may, in turn, lead to a reduction of tasteand-odor occurrences by decreasing algal production.

The Task Force (written commun., 1996) established mean stream-water-quality goals for certain constituents in streams of Cheney Reservoir watershed. These goals were established for base-flow, runoff, and long-term streamflow conditions (table 1). Base flow is defined as stream discharge derived from ground-water sources, whereas runoff conditions occur when streams receive surface-water flow as a direct result of precipitation (Fetter, 1994). Long-term streamflow conditions are those for the period of record (beginning in 1997).

Table 1. Mean stream-water-quality goals established by Cheney Reservoir Task Force (written commun., 1996) for total suspended solids, dissolved nitrate, and total phosphorus in streams of Cheney Reservoir watershed, south-central Kansas, during base-flow, runoff, and long-term streamflow conditions.

\begin{tabular}{cccc}
\hline \multirow{2}{*}{$\begin{array}{c}\text { Water-quality } \\
\text { constituent }\end{array}$} & \multicolumn{3}{c}{$\begin{array}{c}\text { Mean water-quality goal, } \\
\text { in milligrams per liter }\end{array}$} \\
\cline { 2 - 4 } & Base flow & Runoff & $\begin{array}{c}\text { Long-term } \\
\text { streamflow }\end{array}$ \\
\hline $\begin{array}{c}\text { Total suspended } \\
\text { solids }\end{array}$ & 20 & 550 & 100 \\
$\begin{array}{c}\text { Dissolved nitrate as } \\
\text { nitrogen }\end{array}$ & .25 & 6.6 & 1.2 \\
Total phosphorus & .05 & .40 & .10 \\
\hline
\end{tabular}

In 1996, the U.S. Geological Survey (USGS), U.S. Department of the Interior, entered into a cooperative agreement with the city of Wichita, Kansas, with technical assistance provided by the Bureau of Reclamation. The purposes of this agreement were to study and describe spatial occurrence and transport of selected water-quality constituents in streams of the Cheney Reservoir watershed and into and out of Cheney Reservoir. This information has been used by the city of Wichita and the Citizens Management Committee to evaluate the overall effectiveness of implemented BMPs in mitigating surface-water contamination. Results also will support local, State, and Federal goals toward implementing watershed strategies to improve water quality.

USGS has conducted several studies in the Cheney Reservoir watershed since the cooperative agreement was established in 1996. Christensen and Pope (1997) reported on the sampling of 34 surface-water sites to evaluate spatial variability in concentrations of dissolved solids, nutrients, atrazine, and fecal coliform bacteria during low flow. With the exception of dissolved solids, these constituents generally were of nonpointsource origin and probably related to agricultural activities. The 1997 study identified areas of the watershed for long-term monitoring that were examined by Milligan and Pope (2001). Other USGS studies identified phosphorus as a primary constituent of concern that may limit the useful life of the reservoir because it may increase the growth of cyanobacteria thereby increasing the occurrence of taste-and-odor episodes (Pope and Christensen, 1997; Pope, 1998; Pope and Milligan, 2000).

Mau (2001) studied sediment deposition in Cheney Reservoir and associated water-quality trends, and mass transport of phosphorus, nitrogen, selected trace elements, and selected pesticides. The mean concentration of total phosphorus in sediment at 23 sites within the reservoir was $480 \mathrm{mg} / \mathrm{kg}$. An examination of soil cores collected from 43 nonagricultural coring sites in Cheney Reservoir watershed (Pope and others, 2002) produced a median natural concentration for total phosphorus of $166 \mathrm{mg} / \mathrm{L}$. Historical mean total phosphorus concentrations in the bottom sediment in Cheney Reservoir (Mau, 2001) were 2.9 times the natural concentrations in watershed soils (Pope and others, 2002), suggesting phosphorus is accumulating in the sediment.

Smith and others $(2001,2002)$ conducted a study of tasteand-odor causing compounds in Cheney Reservoir during 1999-2000. Geosmin concentrations in the reservoir were variable, and the mean geosmin concentration exceeded the human detection limit of $0.01 \mathrm{ng} / \mathrm{L}$ (Smith and others, 2001, p. 15). MIB was either not detected or detected at very small concentrations during that study, and it was concluded that MIB was unlikely to be a major cause of taste-and-odor occurrences in Cheney Reservoir during the years of their study (1999-2000). Smith and others (2001) also concluded that taste-and-odor occurrences in Cheney Reservoir were strongly linked to algal growth and cyanobacteria in particular. Phosphorus control measures were suggested as a method to alleviate the tasteand-odor occurrences. 


\section{Water Quality and Relation to Taste-and-Odor Compounds, North Fork Ninnescah River and Cheney Reservoir, 1997-2003}

\section{Purpose and Scope}

The purpose of this report is to describe water quality in the North Fork Ninnescah River and Cheney Reservoir and to investigate relations to taste-and-odor compounds. Continuously measured water-quality constituents and water-quality samples are used to to estimate selected constituent concentrations and subsequent taste-and-odor occurrences in the reservoir. Using this information, the probability of geosmin concentrations exceeding $0.01 \mu \mathrm{g} / \mathrm{L}$ (the level at which humans can detect geosmin) can be estimated in real time, which would allow the city of Wichita to adjust water treatment to minimize the effect of taste-and-odor occurrences. The importance of the water quality of the inflows compared to in-lake processes are discussed. The results include 7 years (1997-2003) of data collected from the North Fork Ninnescah River at USGS streamflow-gaging/water-quality sampling site 07144780 (fig. 1) and 2 years (2001-03) of data collected from Cheney Reservoir water-quality sampling site 07144790 (fig. 1).

The information provided in this report can be used by water-resource managers as an approach to estimate taste-andodor occurrence for treatment of taste-and-odor problems in real time using easily measured properties from a continuous, in-situ water-quality monitor. The methods used in this study could be applied to other sites regionally, nationally, and globally.

\section{Description of Study Area}

The Cheney Reservoir watershed includes an estimated $933 \mathrm{mi}^{2}$ of contributing drainage area of the North Fork Ninnescah River and associated tributary streams (table 2). The noncontributing drainage area is about $72 \mathrm{mi}^{2}$ and is located in the extreme upstream part of the watershed and does not supply surface-water runoff to streams in the watershed. The mean annual streamflow from the North Fork Ninnescah River (site 07144780 ) into Cheney Reservoir is $145 \mathrm{ft}^{3} / \mathrm{s}$ (for the period of record, 1966-2003). The conservation-pool storage of the reservoir is about 152,000 acre-ft, with an additional floodcontrol capacity of about 81,000 acre-ft. As of 1998, sediment had filled 27 percent of the reservoir's conservation pool (Mau, 2001). Mean annual streamflow out of Cheney Reservoir is $119 \mathrm{ft}^{3} / \mathrm{s}$ (for the period of record, 1966-2003) (Putnam and Schneider, 2004). Hydraulic residence time during 1997-2003 ranged from 0.9 to 1.5 years (table 3 ).

The North Fork Ninnescah River is the major inflow to Cheney Reservoir; however, there also are several small tributaries that contribute surface water and are a possible source for nutrients and other chemicals. Water-budget analysis indicates that during 1997-2003 the North Fork Ninnescah River accounted for an average of about 70 percent of the water flowing into the reservoir (table 3). This water-budget analysis, however, does not account for evapotranspiration losses or ground-water contributions and losses, which may be substantial. For example, average annual pan evaporation is about
Table 2. Streamflow-gaging/water-quality sampling sites in Cheney Reservoir watershed, south-central Kansas.

\begin{tabular}{|c|c|c|}
\hline $\begin{array}{c}\text { U.S. } \\
\text { Geological } \\
\text { Survey site } \\
\text { identification } \\
\text { number }\end{array}$ & Sampling-site name & $\begin{array}{c}\text { Contributing } \\
\text { drainage area } \\
\text { (square miles) }\end{array}$ \\
\hline 07144780 & $\begin{array}{l}\text { North Fork Ninnescah River above } \\
\text { Cheney Reservoir, Kansas }\end{array}$ & 734 \\
\hline 07144790 & $\begin{array}{l}\text { Cheney Reservoir near Cheney } \\
\text { Dam, Kansas }\end{array}$ & 933 \\
\hline
\end{tabular}

76 in. at nearby Fall River Lake (Mary Knapp, State Climatologist, written commun., October 27, 2005).

Cheney Reservoir, like most large reservoirs in Kansas, is a bottom discharge reservoir. Because of this, the possibility exists that the quality of the discharged water and the quality of the reservoir surface water, where physical properties were continuously monitored, may vary due to thermally induced waterdensity gradients that, at certain times of the year, may produce chemical stratification in a reservoir (Reid and Wood, 1976). However, on the basis of a limited number of vertical profiles of physical properties and comparisons between analytical results of water samples from near the surface and bottom of the reservoir, thermal and chemical stratification rarely occur in Cheney Reservoir (U.S. Fish and Wildlife Service, 1996, p. C1C24). Smith and others (2001, p. 10; 2002) came to a similar conclusion. The lack of strong thermal stratification in Cheney Reservoir is primarily because of the relatively shallow depths and persistent winds averaging $12 \mathrm{mi} / \mathrm{h}$ annually (Sedgwick County, 2004).

Land use in the watershed is predominantly agricultural with about 52 percent of the land used for major crop production (corn, grain sorghum, soybeans, and wheat) (Pope, 1998, p. 4). Estimated cropland acreage for 2003 included about 41,000 acres of corn, 114,000 acres of grain sorghum, 25,500 acres of soybeans, and 210,000 acres of wheat. Livestock inventories included about 67,000 cattle. Most of the cattle were pastured; however, many small dairies and feedlots operate within the watershed (Christensen and Pope, 1997). Hogs and pigs also are raised in the basin, but numbers are not reported due to issues related to confidentiality (crops and livestock data from Kansas Department of Agriculture and U.S. Department of Agriculture, 2004).

The population of the watershed is less than 4,000 people most of whom are associated with the approximately 1,000 farms in the watershed (Cheney Reservoir Task Force Committee, written commun., 1996). The population of the six largest towns in 2003 ranged from 161 people in Preston to 1,097 in Stafford (Policy Research Institute, 2004).

The North Fork Ninnescah River Valley and the surrounding plains are underlain by consolidated rocks (mainly shale with thin layers of limestone, dolomite, siltstone, sandstone, gypsum, and salt) of Permian age (230 to 280 million years old) 
Table 3. Annual water budgets for Cheney Reservoir, south-central Kansas, 1997-2003.

[all values in acre-feet and rounded to three significant figures, except as indicated]

\begin{tabular}{|c|c|c|c|c|c|c|c|}
\hline Calendar year & $\begin{array}{l}\text { Change in } \\
\text { reservoir } \\
\text { storage }^{1}\end{array}$ & $\begin{array}{c}\text { Discharge } \\
\text { from reservoir } 2\end{array}$ & $\begin{array}{l}\text { Water } \\
\text { withdrawals by } \\
\text { city of Wichita }\end{array}$ & $\begin{array}{l}\text { Net inflow } \\
\text { volume from all } \\
\text { sources }^{4}\end{array}$ & $\begin{array}{c}\text { Inflow from the } \\
\text { North Fork } \\
\text { Ninnescah } \\
\text { River }^{2}\end{array}$ & $\begin{array}{c}\text { Percentage of } \\
\text { inflow } \\
\text { contributed by } \\
\text { North Fork } \\
\text { Ninnescah } \\
\text { River }\end{array}$ & $\begin{array}{c}\text { Reservoir } \\
\text { water } \\
\text { residence time } \\
\text { (years) }^{5}\end{array}$ \\
\hline 1997 & 6,690 & 68,200 & 34,100 & 109,000 & 81,600 & 74.9 & 1.46 \\
\hline 1998 & $-8,870$ & 117,000 & 44,200 & 152,000 & 104,000 & 68.4 & .94 \\
\hline 1999 & $-44,600$ & 130,000 & 38,100 & 124,000 & 87,600 & 70.6 & .87 \\
\hline 2000 & 45,400 & 44,200 & 41,500 & 131,000 & 91,500 & 69.8 & 1.51 \\
\hline 2001 & $-34,200$ & 111,000 & 46,200 & 123,000 & 97,000 & 78.9 & .96 \\
\hline 2002 & 34,000 & 500 & 42,000 & 76,500 & 59,600 & 77.9 & 2.43 \\
\hline 2003 & $-8,230$ & 97,400 & 33,800 & 123,000 & 82,000 & 66.7 & 1.17 \\
\hline \multicolumn{8}{|c|}{${ }^{1}$ Conservation pool storage is about 152,000 acre-feet. } \\
\hline
\end{tabular}

covered by unconsolidated fluvial (mainly water transported sand and gravel) and aeolian (mainly windblown silt and clay) deposits of Pleistocene age (less than 1.5 million years old) (Zeller, 1968). The unconsolidated deposits are a source of water for domestic supply, irrigation, and livestock and range in thickness from 0 to $660 \mathrm{ft}$ with little or no saturated thickness in the eastern part of the Red Rock Creek subwatershed (fig. 1) to more than $160 \mathrm{ft}$ in the northern part of Pratt County (Bayne, 1956; Hansen, 1991).

Topography in the Cheney Reservoir watershed ranges from flat to gently sloping hills. Total topographic relief is about $550 \mathrm{ft}$, with maximum local relief (within $1 \mathrm{mi}$ ) of about $50 \mathrm{ft}$. Soils in the Cheney Reservoir watershed generally are classified as clayey loam on the uplands to sand or sandy loam in low-lying areas or where slopes are less than about 3 percent. Many of the soils in the watershed are subject to erosion by wind and rainfall runoff (Rockers and others, 1966).

The mean annual temperature in the study area is approximately $56{ }^{\circ} \mathrm{F}$ with January being the coldest month (average temperature $30.4^{\circ} \mathrm{F}$ ) and July being the warmest month (average temperature $80.5^{\circ} \mathrm{F}$ ) (Kansas Department of Agriculture and U.S. Department of Agriculture, 2004). Mean annual precipitation is about 29 in. (1971-2000), which occurs mainly between April and September (Kansas Department of Agriculture and U.S. Department of Agriculture, 2004).

\section{Study Methods}

\section{Overview}

Two sites were monitored for this study, the North Fork Ninnescah River above Cheney Reservoir (site 07144780 , fig. 1) and Cheney Reservoir near Cheney Dam (site 07144790, fig. 1). At both sites, continuously recorded water-quality monitoring and discrete water-quality samples were used to assess water quality. Monitoring for water-quality constituents began in 1997 for the North Fork Ninnescah River (hereinafter called the inflow site) and in 2001 for Cheney Reservoir (hereinafter called the reservoir site). Continuous water-quality monitors were installed in October 1998 (at the inflow site) and in March 2001 (at the reservoir site).

\section{Continuous Water-Quality Monitors}

Continuous stream stage (water-surface elevation) was recorded at each site using pressure transducers and electronic data-collection platforms. Streamflow (in cubic feet per second) was calculated for the inflow site by relating stream stage to stage/streamflow relations using methods presented in Kennedy (1983). Streamflow measurements were made about every 6 weeks to develop and maintain the stage/streamflow relation.

The water-quality monitor at the inflow site measured physical water-quality properties including specific conductance, $\mathrm{pH}$, water temperature, turbidity, and dissolved oxygen. The monitor in Cheney Reservoir, located near the dam on the 


\section{Water Quality and Relation to Taste-and-Odor Compounds, North Fork Ninnescah River and Cheney Reservoir, 1997-2003}

walkway to the control tower in the reservoir, was instrumented with the same sensors as at the inflow site, with the addition of fluorescence measured at a wavelength range from 650 to $700 \mathrm{~nm}$. When measured at this wavelength, fluorescence may provide an estimate of total chlorophyll concentration (all species; YSI, 2005).

Each of the sensors (specific conductance, $\mathrm{pH}$, water temperature, turbidity, dissolved oxygen, and fluorescence) on the water-quality monitors installed at the inflow and reservoir sites has a specific range of operation. Specific conductance, $\mathrm{pH}$, water temperature, dissolved oxygen, and fluorescence sensors have wide ranges of operation (Wagner and others, 2000) that were not exceeded during this study and are not likely to be exceeded in streams or lakes in Kansas. The turbidity sensor at these sites has a maximum reading of about 1,700 FNU (formazin nephelometric units; Anderson, 2004) that was exceeded during this study for 3 days in September 2001 at the inflow site. Turbidity readings greater than the maximum value could cause underestimation for concentrations of water-quality constituents that incorporate turbidity as an explanatory variable in regression models. However, for these sites this occurrence is infrequent as is apparent by the small number of occurrences during the study.

Turbidity was measured with a YSI 6026 turbidity sensor beginning in 1997 at the inflow site. On April 16, 2002, a YSI 6136 sensor (a more recently developed sensor) was installed at the reservoir site. A YSI 6026 was operated alongside the YSI 6136 from May through July 2002. Turbidity measurements made with these different sensors are not identical (Sadar, 2002; Ziegler, 2003; Anderson, 2004). The YSI 6026 was selected to maintain consistency between the inflow and reservoir sites. On August 5, 2002, the YSI 6026 was permanently installed at the reservoir site to replace the YSI 6136. On the basis of the comparison between the two instruments, a +38 -percent correction was applied to the data from the 6136 sensor.

The continuous data (stream stage and water quality) were recorded at 30- to 60-minute intervals and were transmitted every 4 hours via satellite to the USGS office in Lawrence, Kansas, and made available in real time on the World Wide Web at http://ks.waterdata.usgs.gov/nwis. The water-quality monitors were inspected or cleaned at least monthly to maintain calibration, according to procedures described in Wagner and others (2000).

\section{Discrete Water-Quality Samples}

Water samples from the inflow site were collected either manually (manual samples) (Horowitz and others, 1994) or with an automatic sampler (automatic samples). The automatic sampler used during this study was capable of collecting four 1-gal samples before service was required. All low-flow and some runoff samples were collected manually. Most runoff samples were collected with the automatic sampler. Manual samples were collected to provide a depth- and width-integrated composite sample representative of the average chemical composition of the stream cross-sectional area. Automatic samples were collected from a single point in the stream crosssectional area and, therefore, may not be representative of the average chemical composition of the stream cross-sectional area at the time of sample collection. On the basis of data collected between 1997 and 2000, the manual sample concentrations were 99 percent of the automated concentrations for dissolved constituents. For total suspended solids and total phosphorus, manual sample concentrations were 89 and 94 percent of the automated concentrations, respectively (Milligan and Pope, 2001, p. 6-7). All water samples collected from the reservoir site were collected manually, just below the water surface, and were not depth and width integrated.

Water-quality samples were collected by USGS personnel and delivered to the USGS National Water-Quality Laboratory (NWQL) in Lakewood, Colorado, for total kjeldahl nitrogen (ammonia plus organic nitrogen) and chlorophyll- $a$ analysis (chlorphyll- $a$ was measured by high-performance liquid chromatography-HPLC); the USGS Organic Geochemistry Research Laboratory, in Lawrence Kansas, for geosmin and MIB (Zimmerman and others 2002), environmental microcystin analysis (environmental microcystin is a measure of ambient microcystin concentration), and untreated whole water analysis by a commercially available enzyme-linked immunosorbent assay (ELISA); the USGS Sediment Laboratory in Iowa City, Iowa, for suspended-sediment analysis (Gray and others, 2000); Montgomery Watson Harza (MWH) Laboratories, Monrovia, California, for geosmin and MIB analysis; and BSA Environmental Services, Beachwood, Ohio, for algal identification and enumeration. The Wichita Water and Sewer Department Laboratory in Wichita, Kansas, provided the analyses for phosphorus, orthophosphorus, nitrate plus nitrite nitrogen, ammonia, major ions, and fecal coliform bacteria (Clesceri and others, 1998).

Water-quality data serve as a basis for statistical regression analysis to develop relations between easily monitored or determined water-quality properties (streamflow, specific conductance, $\mathrm{pH}$, water temperature, turbidity, dissolved oxygen, fluorescence, day-of-year) and physical, chemical, and biological characteristics of inflow and reservoir water. Data collected from August 1999 through October 2000 by Smith and others (2002) are used to supplement reservoir data in some phosphorus and geosmin analyses.

\section{Development of Regression Models, Uncertainty, and Probability}

Previous USGS studies in Kansas (Christensen and others, 2000; Christensen, 2001) have used regression analysis and resulting empirical models to estimate the concentration, load, and yield of water-quality constituents in streams of southcentral Kansas. Rasmussen and Ziegler (2003) used regression models to estimate bacteria density in streams throughout Kansas. Mau and others (2004) used similar regression approaches to describe and estimate taste-and-odor occurrences in Lake 
Olathe in northeast Kansas. The models were developed for these studies by relating discrete values of continuously measured physical characteristics of water quality, such as specific conductance or turbidity, to discrete-sample concentrations or densities of water-quality constituents such as suspended sediment, chloride, total nitrogen, total phosphorus, and bacteria. The regression models then were used with continuous data to estimate concentrations, densities, loads, and yields of selected water-quality constituents and the probability that concentrations or densities exceed water-quality criteria in streams. The continuous water-quality monitors installed at the North Fork Ninnescah River and Cheney Reservoir sites were used in a similar manner in this report.

Data from discrete water-quality samples were used to develop regression equations for estimating concentrations or densities of water-quality constituents in the North Fork Ninnescah River and Cheney Reservoir. The simplest regression equation can be expressed as:

$$
y_{i}=m x_{i}+b+e_{i},
$$

where

$i$ is $1,2, \ldots, n$;

$y_{i}$ is the $i^{\text {th }}$ observation of the response (dependent) variable;

$m$ is the slope of the regression line;

$x_{i}$ is the $i^{\text {th }}$ observation of the explanatory (independent) variable;

$b$ is the intercept;

$e_{i}$ is the random error for the $i^{\text {th }}$ observation; and

$n$ is the number of samples.

The variables $m$ and $b$ must be estimated from the data set. The most common estimation technique is called least-squares estimation (Helsel and Hirsch, 1992). The error term, $e_{i}$, is assumed to be normally distributed with a mean equal to zero and a constant variance, $s^{2}$.

The first step in development of a regression equation was to plot each possible explanatory variable relative to the response variable and evaluate patterns in the data. The possible explanatory variables included each of the sensor measurements of the water-quality monitor (specific conductance, $\mathrm{pH}$, water temperature, turbidity, dissolved oxygen, and fluorescence), streamflow, and time (to account for seasonal differences). Next, a step-wise regression procedure (Ott, 1993, p. 656) and an overall method procedure (Helsel and Hirsch, 1992, p. 312-314) were used to determine which explanatory variable or variables to include in the regression equation for each water-quality constituent. The overall method evaluated all possible regression equations. If there were several acceptable equations, the one with the smallest prediction error sum of squares (PRESS) statistic was chosen. The PRESS is one of the best measures of the goodness of fit of a regression equation (Helsel and Hirsch, 1992, p. 248). Additionally, explanatory variables were included in an equation only if there was a physical basis or explanation for their inclusion.

In addition to the PRESS, two common diagnostic statistic equations were used to evaluate regression equations. These are the mean square error (MSE) and the coefficient of determination $\left(\mathrm{R}^{2}\right)$. MSE is calculated as follows:

$$
M S E=\Sigma\left[y_{i}-E\left(y_{i}\right)\right]^{2} / n-2,
$$

where $y_{i} \quad$ represents the value of $y$ at the $i^{\text {th }}$ data point;

$E\left(y_{i}\right) \quad$ is the estimated value of $y$ at the $i^{\text {th }}$ data point (where $E\left(y_{i}\right)=m x_{i}+b$ ); and

$n$ is the number of samples.

The MSE is determined for each equation to assess variance between estimated and measured values.

$M S E$ is a dimensional measure. Dimensionless measures often are required in practice for the purpose of comparing constituents or properties with different dimensions (units of measure). A dimensionless measure of fitting $y$ on $x$ is the $R^{2}$ (coefficient of determination), or the fraction of the variance explained by the regression:

$$
R^{2}=1.0-(S S E / S S y)
$$

SSE and SSy are calculated as follows:

$$
\begin{gathered}
S S E=\Sigma\left[y_{i}-E\left(y_{i}\right)\right]^{2}, \text { and } \\
S S y=\Sigma\left(y_{i}-\bar{y}\right)^{2},
\end{gathered}
$$

in which $\bar{y}$ is the mean of $y$.

Graphical plots were constructed to examine the linearity of the relation between explanatory and response variables. Certain explanatory variables and response variables were transformed to convert all equations presented herein to linear equations. Transformations (for example, base-10 logarithmic) of variables can eliminate curvature and simplify analysis of the data (Ott, 1993, p. 454). For response variables that were transformed, retransformation can cause an underestimation of concentrations or densities over a long period of time. Applying Duan's bias correction factor (Duan, 1983) to estimated concentrations or densities allows correction for this underestimation. Cohn and others (1989), Gilroy and others (1990), and Hirsch and others (1993) provide additional information on interpreting the results of regression-based concentration estimates.

Water-quality concentrations and densities that were less than analytical method detection limits were arbitrarily set at one-half the method detection limit (MDL) for the development of regression equations. Because very few of the constituent measurements used for model development were less than the MDL, this procedure was not expected to have a substantial effect on the equations. However, there were several censored values (those less than the detection limit) for total suspended solids ( 4 of 19 samples from the reservoir site), nitrite plus nitrate (6 of 19 samples from the reservoir site), orthophosphorus (12 of 25 samples from the inflow site and 5 of 33 samples from the reservoir site), and geosmin ( 3 of 19 samples from the reservoir site). Therefore, the substitution procedure applied to the censored data for these constituents may have an effect on the models and resulting estimated values. 


\section{Water Quality and Relation to Taste-and-Odor Compounds, North Fork Ninnescah River and Cheney Reservoir, 1997-2003}

Probabilities of exceeding a water-quality criteria or goal were calculated according to methods explained at http://ks.water.usgs.gov/Kansas/rtqw/regression.shtml. The probability of exceedence is a useful measure for providing water-quality managers with a single value for decisionmaking.

\section{Quality Assurance and Quality Control}

A primary data objective was to ensure that samples were representative of the water bodies under investigation. Quality assurance was assessed with specific procedures, such as instrument calibration, to ensure data reliability. Quality control was assessed through the collection of replicate samples to understand the error associated with sample data. The median analytical variation between analyses of replicate samples for total suspended solids, dissolved nitrate, and phosphorus for all sites in Cheney Reservoir watershed (as reported by Milligan and Pope, 2001) was 0.4, 3.6, and 3.7 percent, respectively. Standard reference samples also were analyzed for dissolved nitrate and total phosphorus to determine the accuracy of laboratory analyses. Median variations were 7.6 and 6.3 percent for dissolved nitrate and total phosphorus, respectively, indicating an acceptable degree of accuracy. A more detailed description of quality-control procedures is presented in Milligan and Pope (2001).

\section{Assessment of Water Quality and Relation to Taste-and-Odor Compounds}

\section{Measured Water-Quality Constituents}

Results of sample collection for the inflow and reservoir sites are summarized in table 4. More samples were collected for some constituents due in part to the data-collection start date. The additional algal data collected from Cheney Reservoir, but not the inflow, included in-situ fluorescence, chlorophyll- $a$ (an indicator of phytoplankton biomass), geosmin, MIB, microcystin, and phytoplankton analysis.

\section{Comparison to Water-Quality Criteria and Goals}

Physical properties, solids, and sediment are important to understanding surface-water quality, and consequently certain properties are evaluated with respect to water-quality criteria (table 4). Of the environmental variables listed in table 4, those with State of Kansas or U.S. Environmental Protection Agency (USEPA)-proposed water-quality criteria are $\mathrm{pH}$, dissolved oxygen, and turbidity. Kansas Department of Health and Environment (KDHE) (2001) has established an aquatic-life support criterion $\mathrm{pH}$ range, and USEPA (2002) has established an SDWR (Secondary Drinking Water Regulation) $\mathrm{pH}$ range of 6.5-8.5 standard units for surface water. SDWRs are nonenforceable Federal guidelines regarding cosmetic or aesthetic characteristics of drinking water (U.S. Environmental Protection Agency, 2002). The 6.5-8.5 standard unit $\mathrm{pH}$ range was exceeded at the inflow site (6 of 133 samples) and the reservoir site (21 of 35 samples). The State of Kansas aquaticlife support criterion for dissolved oxygen is a minimum of $5.0 \mathrm{mg} / \mathrm{L}$. Dissolved oxygen concentrations did not fall below $5.0 \mathrm{mg} / \mathrm{L}$ in samples collected at either site during the study.

USEPA has proposed new water-quality criteria for turbidity and nutrients on the basis of 14 ecoregions of the United States. The Cheney Reservoir watershed is in Ecoregion V (South-Central Cultivated Great Plains) (U.S. Environmental Protection Agency, 2001a). USEPA has proposed turbidity criterion for Ecoregion $\mathrm{V}$ of 7.83 nephelometric turbidity units (NTU) for streams and a microbiology criterion of 5.0 NTU (U.S. Environmental Protection Agency, 2001a; U.S. Environmental Protection Agency, 2002). USEPA criteria are given in NTU, whereas the instruments used in this study measure formazin nephelometric units (FNU). These units are not precisely equivalent, but USEPA criteria are used here for an approximate comparison. Turbidity readings ranged from 3.1 to 1,200 FNU in water from the inflow site and from 1.6 to $40 \mathrm{FNU}$ in water from the reservoir site (table 4).

Although total suspended solids (TSS) and suspendedsediment concentration (SSC) do not have USEPA established water-quality criteria, the Cheney Reservoir Task Force has established a long-term mean water-quality goal for TSS of $100 \mathrm{mg} / \mathrm{L}$ at the inflow site (Cheney Reservoir Task Force, written commun., 1996). The mean TSS concentration in samples collected at the inflow site during the study period was $250 \mathrm{mg} / \mathrm{L}$ (table 4).

Dissolved solids are an important indicator of the suitability of water for drinking, irrigation, and industrial use. Excessively large concentrations of dissolved solids are objectionable in drinking water because of possible physiological effects, strong mineral tastes, increased treatment costs, and excessive corrosion in plumbing (U.S. Environmental Protection Agency, 1986). The major constituents of dissolved solids are the ions calcium, magnesium, sodium, potassium, bicarbonate, carbonate, sulfate, and chloride. USEPA (2002) has established a SDWR for dissolved solids in drinking water of $500 \mathrm{mg} / \mathrm{L}$. Dissolved-solids concentrations in water from the inflow site exceeded the SDWR in 59 of 129 samples. Dissolved-solids concentrations in water from the reservoir site exceeded the SDWR in 1 of 19 samples.

Of the chemicals that make up dissolved solids, sodium, sulfate, chloride, and fluoride have water-quality criteria. USEPA (2002) has established a Drinking Water Advisory (DWA) for sodium of $20 \mathrm{mg} / \mathrm{L}$ for individuals on a $50-\mathrm{mg} / \mathrm{d}$ restricted sodium diet. Sodium concentrations in all water samples, except one, collected at the inflow site exceeded the $20-\mathrm{mg} / \mathrm{L}$ advisory. Sodium concentrations ranged from 20 to $180 \mathrm{mg} / \mathrm{L}$ in water from the inflow site and from 88 to $116 \mathrm{mg} / \mathrm{L}$ in water from the reservoir site (table 4). Chloride concentrations ranged from 34 to $289 \mathrm{mg} / \mathrm{L}$ in water from the inflow site and from 116 to $162 \mathrm{mg} / \mathrm{L}$ in water from the reservoir site. 
Table 4. Statistical summary of streamflow and water-quality data collected from North Fork Ninnescah River above Cheney Reservoir and Cheney Reservoir, south-central Kansas, 1997-2003.

[n, number of samples; mm-dd-yyyy, month-day-year; $\mathrm{ft}^{3} / \mathrm{s}$, cubic feet per second; --, not applicable or not determined; $\mu \mathrm{S} / \mathrm{cm}$, microsiemens per centimeter at $25 \mathrm{degrees}$ Celsius; $\mathrm{AL}$, State of Kansas aquatic-life support criteria; SDWR, Secondary Drinking Water Regulation; FNU, formazin nephelometric units; NTU, nephelometric turbidity units; V, U.S. Environmental Protection Agency (USEPA) recommended criteria for streams and rivers in Ecoregion V; $\mu \mathrm{g} / \mathrm{L}$, micrograms per liter; Micro, USEPA microbiology water-quality criteria; $\mathrm{mg} / \mathrm{L}$, milligrams per liter; $\mathrm{CaCO}_{3}$, calcium carbonate; AGI, State of Kansas agricultural irrigation criteria; AGL, State of Kansas agricultural livestock criteria; DWA, Drinking Water Advisory Level; ALA, State of Kansas aquatic-life support criteria, acute; ALC, State of Kansas aquatic-life support criteria, chronic; MCL, Maximum Contaminant Level; col/100 mL, colonies per 100 milliliters of sample; KS PCRC, State of Kansas primary contact recreation criteria; KS SCRC, State of Kansas secondary contact recreation criteria; <, less than]

\begin{tabular}{|c|c|c|c|c|c|c|c|c|}
\hline \multirow{2}{*}{$\begin{array}{l}\text { Water-quality property or chemical } \\
\text { (unit of measure) }\end{array}$} & \multicolumn{7}{|c|}{ Inflow site (fig. 1) } & \multirow[b]{2}{*}{ Water-quality criteria } \\
\hline & $\mathrm{n}$ & Range & Median & Mean & $\begin{array}{l}\text { Standard } \\
\text { deviation }\end{array}$ & $\begin{array}{c}\text { Start date } \\
\text { (mm-dd-yyyy) }\end{array}$ & $\begin{array}{c}\text { End date } \\
\text { (mm-dd-yyyy) }\end{array}$ & \\
\hline \multicolumn{9}{|c|}{ Physical properties, suspended solids, sediment, and alkalinity } \\
\hline Streamflow $\left(\mathrm{ft}^{3} / \mathrm{s}\right)$ & 155 & $9.0-3,700$ & 190 & 450 & 670 & 01-08-1997 & 04-21-2003 & -- \\
\hline Specific conductance, field $(\mu \mathrm{S} / \mathrm{cm})$ & 151 & $198-1,370$ & 949 & 862 & 312 & 01-08-1997 & 09-03-2003 & -- \\
\hline $\mathrm{pH}$, field (standard units) & 133 & $6.4-9.0$ & 7.9 & 7.9 & .44 & 01-08-1997 & 04-21-2003 & 6.5-8.5 $\left(\mathrm{AL}^{1}, \mathrm{SDWR}^{2}\right)$ \\
\hline Water temperature, field (degrees Celsius) & 83 & $0.70-31$ & 18 & 17 & 8.9 & 01-08-1997 & 09-03-2003 & -- \\
\hline Dissolved oxygen, field $(\mathrm{mg} / \mathrm{L})$ & 62 & $6.0-13$ & 10 & 9.9 & 1.8 & 01-08-1997 & 04-21-2003 & $5.0(\mathrm{AL})^{1}$ \\
\hline Turbidity, laboratory (FNU) & 130 & $3.1-1,200$ & 88 & 140 & 170 & 01-08-1997 & $04-21-2003$ & $7.83 \mathrm{NTU}(\mathrm{V})^{3}, 5.0 \mathrm{NTU}(\text { Micro })^{2}$ \\
\hline In-situ chlorophyll ( $\mu \mathrm{g} / \mathrm{L})$ & 2 & $14.5-24.3$ & 19.4 & 19.4 & 6.93 & $03-18-2003$ & 03-19-2003 & -- \\
\hline Total suspended solids (mg/L) & 130 & $8.4-1,700$ & 160 & 250 & 290 & 01-08-1997 & 04-21-2003 & -- \\
\hline Suspended sediment (mg/L) & 24 & $22-2,150$ & 93.3 & 375 & 601 & 05-13-1999 & 04-21-2003 & -- \\
\hline Alkalinity $\left(\mathrm{mg} / \mathrm{L}\right.$ as $\left.\mathrm{CaCO}_{3}\right)$ & 27 & $74-222$ & 153 & 146 & 41.6 & 07-10-1997 & 04-21-2003 & -- \\
\hline \multicolumn{9}{|c|}{ Dissolved solids and major ions } \\
\hline Dissolved solids (mg/L) & 129 & $140-707$ & 472 & 461 & 168 & 01-08-1997 & 04-21-2003 & $500(\mathrm{SDWR})^{2}$ \\
\hline Calcium (mg/L) & 130 & $20-88.7$ & 51 & 53 & 18 & 01-08-1997 & 04-21-2003 & -- \\
\hline Magnesium (mg/L) & 130 & $3.5-14$ & 9.2 & 8.8 & 2.9 & 01-08-1997 & 04-21-2003 & -- \\
\hline Sodium $(\mathrm{mg} / \mathrm{L})$ & 130 & $20-180$ & 101 & 104 & 46 & 01-08-1997 & 04-21-2003 & $20(\mathrm{DWA})^{2}$ \\
\hline Potassium (mg/L) & 130 & $2.5-8.2$ & 4.9 & 5.0 & 1.5 & 01-08-1997 & 04-21-2003 & -- \\
\hline Bicarbonate (mg/L) & 27 & $86-271$ & 187 & 178 & 51.0 & 07-10-1997 & 04-21-2003 & -- \\
\hline Sulfate $(\mathrm{mg} / \mathrm{L})$ & 27 & $11-61$ & 38 & 36 & 14 & 07-10-1997 & 04-21-2003 & 250 (DWA), 1,000 (AGL) $)^{1,2}$ \\
\hline Chloride (mg/L) & 27 & $34-289$ & 159 & 154 & 71 & 07-10-1997 & 04-21-2003 & $250(\text { SDWR })^{2}, 860(\mathrm{ALA})^{1}$ \\
\hline Fluoride (mg/L) & 130 & $0.02-0.57$ & .30 & .30 & .07 & 01-08-1997 & 04-21-2003 & $4.0(\mathrm{MCL})^{2}, 1.0(\mathrm{AGI})^{1}, 2.0(\mathrm{AGL})^{1}$ \\
\hline \multicolumn{9}{|c|}{ Nutrients } \\
\hline Nitrite plus nitrate as nitrogen, dissolved $(\mathrm{mg} / \mathrm{L}$ ) & 124 & $<0.02-2.4$ & .66 & .78 & .49 & 01-08-1997 & $04-21-2003$ & $10(\mathrm{MCL})^{2}, 100(\mathrm{AGL})^{1}$ \\
\hline Ammonia plus organic, total, as nitrogen $(\mathrm{mg} / \mathrm{L})$ & 124 & $0.34-4.4$ & 1.5 & 1.6 & .82 & 01-08-1997 & $04-21-2003$ & -- \\
\hline Ammonia, as nitrogen $(\mathrm{mg} / \mathrm{L})$ & 130 & $0.02-0.39$ & .07 & .08 & .06 & 01-08-1997 & 04-21-2003 & -- \\
\hline Phosphorus total (mg/L) & 128 & $<0.03-1.8$ & .27 & .33 & .28 & 01-08-1997 & 04-21-2003 & $0.067\left(\mathrm{~V}_{\text {stream }}\right)^{3}, 0.033\left(\mathrm{~V}_{\text {lake }}\right)^{4}$ \\
\hline Orthophosphorus, as phosphorus (mg/L) & 129 & $<0.01-0.45$ & .05 & .07 & .07 & 01-08-1997 & 04-21-2003 & -- \\
\hline \multicolumn{9}{|c|}{ Bacteria, biochemical } \\
\hline Fecal coliform (col/100 mL) & 62 & $<4-65,000$ & 320 & 4,300 & 10,000 & 01-08-1997 & $08-25-2003$ & $200(\text { KS PCRC })^{1}, 2000(\text { KS SCRC })^{1}$ \\
\hline
\end{tabular}


Table 4. Statistical summary of streamflow and water-quality data collected from North Fork Ninnescah River above Cheney Reservoir and Cheney Reservoir, south-central Kansas, 1997-2003.-Continued

[n, number of samples; mm-dd-yyyy, month-day-year; $\mathrm{ft}^{3} / \mathrm{s}$, cubic feet per second; --, not applicable or not determined; $\mu \mathrm{S} / \mathrm{cm}$, microsiemens per centimeter at 25 degrees Celsius; AL, State of Kansas aquatic-life support criteria; SDWR, Secondary Drinking Water Regulation; FNU, formazin nephelometric units; NTU, nephelometric turbidity units; V, U.S. Environmental Protection Agency (USEPA) recommended criteria for streams and rivers in Ecoregion V; $\mu \mathrm{g} / \mathrm{L}$ micrograms per liter; Micro, USEPA microbiology water-quality criteria; $\mathrm{mg} / \mathrm{L}$, milligrams per liter; $\mathrm{CaCO}_{3}$, calcium carbonate; $\mathrm{AGI}$, State of Kansas agricultural irrigation criteria; AGL, State of Kansas agricultural livestock criteria; DWA, Drinking Water Advisory Level; ALA, State of Kansas aquatic-life support criteria, acute; ALC, State of Kansas aquatic-life support criteria, chronic; MCL, Maximum Contaminant Level; col/100 mL, colonies per 100 milliliters of sample; KS PCRC, State of Kansas primary contact recreation criteria; KS SCRC, State of Kansas secondary contact recreation criteria; <, less than]

\begin{tabular}{|c|c|c|c|c|c|c|c|c|}
\hline \multirow{2}{*}{$\begin{array}{l}\text { Water-quality property or chemical } \\
\text { (unit of measure) }\end{array}$} & \multicolumn{8}{|c|}{ Reservoir site (fig. 1) } \\
\hline & $\mathrm{n}$ & Range & Median & Mean & $\begin{array}{l}\text { Standard } \\
\text { deviation }\end{array}$ & $\begin{array}{c}\text { Start date } \\
\text { (mm-dd-yyyy) }\end{array}$ & $\begin{array}{c}\text { End date } \\
\text { (mm-dd-yyyy) }\end{array}$ & Water-quality criteria \\
\hline
\end{tabular}

Streamflow $\left(\mathrm{ft}^{3} / \mathrm{s}\right)$

Specific conductance, field $(\mu \mathrm{S} / \mathrm{cm})$

$\mathrm{pH}$, field (standard units)

Water temperature, field (Celsius)

Dissolved oxygen, field $(\mathrm{mg} / \mathrm{L})$

Physical properties, suspended solids, sediment, and alkalinity

Turbidity, laboratory (FNU)

In-situ chlorophyll $(\mu \mathrm{g} / \mathrm{L})$

Total suspended solids (mg/L)

Suspended sediment $(\mathrm{mg} / \mathrm{L})$

Alkalinity $\left(\mathrm{mg} / \mathrm{L}\right.$ as $\left.\mathrm{CaCO}_{3}\right)$

Dissolved solids $(\mathrm{mg} / \mathrm{L})$

Calcium (mg/L)

Magnesium (mg/L)

Sodium $(\mathrm{mg} / \mathrm{L})$

Potassium $(\mathrm{mg} / \mathrm{L})$

Bicarbonate $(\mathrm{mg} / \mathrm{L})$

Sulfate $(\mathrm{mg} / \mathrm{L})$

Chloride $(\mathrm{mg} / \mathrm{L})$

Fluoride $(\mathrm{mg} / \mathrm{L})$
$761-911$

$8.0-9.0$

$0.60-28$

$5.9-18$

880

880
8.6

8.6
6.0

6.0
9.7

854

8.6

12

$1.6-40$

$1.6-40$
$0-268$

$<4.0-12$

$2.6-25$

$144-172$

$414-501$

$39-56$

$12-15$

$88-116$

$5.2-5.9$

$176-210$

$34-73$

$116-162$

$0.22-0.48$

$<0.02-0.36$

$0.46-1.4$

$<0.03-0.14$

$<0.03-0.15$

$<0.01-0.09$

$49 \quad 49$

14

101

5.7

14

101
5.7

$193 \quad 192$

42

144

.34

42
142

.34

$\begin{array}{ccc}6.2 & 13 & 11 \\ 9.5 & 11.8 & 8.14 \\ 6.4 & 7.2 & 3.2 \\ 13 & 13 & 6.8 \\ 158 & 158 & 7.8\end{array}$

Dissolved solids and major ions

$\begin{array}{lll}438 & 446 & 25.5\end{array}$

3.8

Nutrients

Ammonia plus organic, total, as nitrogen (mg/L)

Ammonia, as nitrogen (mg/L)

Phosphorus, total $(\mathrm{mg} / \mathrm{L})$

Orthophosphorus, as phosphorus (mg/L)

\section{$<.02$}

.63

.03

$<.03$

$<.03$

.26
.77
.05
.07
$<.03$

3.8
.64

8.1

$--$

1

3.0

05-03-2001

03-19-2002

05-03-2001

05-03-2001

05-03-2001

05-03-2001

05-03-2001

05-03-2001

05-03-2001

05-03-2001

05-03-2001

05-03-2001

05-03-2001

05-03-2001

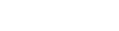

05-03-2001

05-03-2001

05-03-2001

05-03-2001

05-03-2001

07-28-2003

07-28-2003 6.5-8.5 (AL $\left.{ }^{1}, \mathrm{SDWR}^{2}\right)$

07-28-2003

07-28-2003 5.0 (AL) ${ }^{1}$

07-28-2003 7.83 NTU (V) $)^{3}, 5.0 \mathrm{NTU}(\text { Micro })^{2}$

$07-28-2003$

07-28-2003

$07-28-2003$

07-28-2003

07-28-2003 $500(\text { SDWR })^{2}$

07-28-2003

07-28-2003

07-28-2003 20 (DWA) $^{2}$

07-28-2003

07-28-2003

07-28-2003 250 (DWA), 1,000 (AGL) ${ }^{1,2}$

07-28-2003 250 (SDWR $)^{2}, 860$ (ALA) ${ }^{1}$

07-28-2003 4.0 (MCL) $)^{2}, 1.0(\mathrm{AGI})^{1}, 2.0(\mathrm{AGL})^{1}$

07-28-2003 $10(\mathrm{MCL})^{2}, 100(\mathrm{AGL})^{1}$

07-28-2003

07-28-2003

07-28-2003 $0.033(\mathrm{~V})^{4}$

07-28-2003 
Table 4. Statistical summary of streamflow and water-quality data collected from North Fork Ninnescah River above Cheney Reservoir and Cheney Reservoir, south-central Kansas, 1997-2003.-Continued

[n, number of samples; mm-dd-yyyy, month-day-year; $\mathrm{ft}^{3} / \mathrm{s}$, cubic feet per second; --, not applicable or not determined; $\mu \mathrm{S} / \mathrm{cm}$, microsiemens per centimeter at 25 degrees Celsius; AL, State of Kansas aquatic-life support criteria; SDWR, Secondary Drinking Water Regulation; FNU, formazin nephelometric units; NTU, nephelometric turbidity units; V, U.S. Environmental Protection Agency (USEPA) recommended criteria for streams and rivers in Ecoregion V; $\mu \mathrm{g} / \mathrm{L}$, micrograms per liter; Micro, USEPA microbiology water-quality criteria; mg/L, milligrams per liter; CaCO 3 , calcium carbonate; $\mathrm{AGI}_{\text {, State of }}$ Kansas agricultural irrigation criteria; AGL, State of Kansas agricultural livestock criteria; DWA, Drinking Water Advisory Level; ALA, State of Kansas aquatic-life support criteria, acute; ALC, State of Kansas aquatic-life support criteria, chronic; MCL, Maximum Contaminant Level; col/100 mL, colonies per 100 milliliters of sample; KS PCRC, State of Kansas primary contact recreation criteria; KS SCRC, State of Kansas secondary contact recreation criteria; <, less than]

\begin{tabular}{|c|c|c|c|c|c|c|c|c|}
\hline \multirow{2}{*}{$\begin{array}{l}\text { Water-quality property or chemical } \\
\text { (unit of measure) }\end{array}$} & \multicolumn{8}{|c|}{ Reservoir site (fig. 1) } \\
\hline & $\mathrm{n}$ & Range & Median & Mean & $\begin{array}{l}\text { Standard } \\
\text { deviation }\end{array}$ & $\begin{array}{c}\text { Start date } \\
\text { (mm-dd-yyyy) }\end{array}$ & $\begin{array}{c}\text { End date } \\
\text { (mm-dd-yyyy) }\end{array}$ & Water-quality criteria \\
\hline \multicolumn{9}{|c|}{ Bacteria, biochemical } \\
\hline Fecal coliform (col/100 mL) & 19 & $<1-110$ & $<1$ & 9.4 & 24 & 05-03-2001 & 07-28-2003 & $200\left(\right.$ KS PCRC $^{1}, 2000(\text { KS SCRC })^{1}$ \\
\hline $\operatorname{Geosmin}(\mu \mathrm{g} / \mathrm{L})$ & 25 & $<0.003-0.113$ & .006 & .015 & .024 & 05-03-2001 & $07-28-2003$ & -- \\
\hline 2-methylisoborneol, MIB ( $\mu \mathrm{g} / \mathrm{L})$ & 25 & $<0.005-0.011$ & $<.005$ & .006 & .003 & 05-03-2001 & $07-28-2003$ & -- \\
\hline Chlorophyll- $a(\mu \mathrm{g} / \mathrm{L})$ & 34 & $0.53-26$ & 6.7 & 7.4 & 4.6 & 05-03-2001 & $07-28-2003$ & -- \\
\hline Microcystin $(\mu \mathrm{g} / \mathrm{L})$ & 15 & $0.1-2.0$ & .2 & .5 & .6 & $01-21-2003$ & $07-28-2003$ & -- \\
\hline
\end{tabular}

${ }^{1}$ Kansas Department of Health and Environment, 2001.

${ }^{2}$ U.S. Environmental Protection Agency, 2002.

${ }^{3}$ U.S. Environmental Protection Agency, 2001a.

${ }^{4}$ U.S. Environmental Protection Agency, $2001 \mathrm{~b}$. 
KDHE has established a secondary water-quality criteria for chloride in drinking water $(250 \mathrm{mg} / \mathrm{L})$ and for acute aquatic-life support $(860 \mathrm{mg} / \mathrm{L})($ Kansas Department of Health and Environment, 2001). Concentrations of chloride in 2 of 27 water samples from the inflow site exceeded the drinking-water criterion. No water-quality samples exceeded established criteria for sulfate or fluoride. There are no water-quality criteria for calcium, magnesium, potassium, or bicarbonate.

Excessive nitrate concentrations in drinking water can pose adverse health effects on humans. Concentrations in excess of $10 \mathrm{mg} / \mathrm{L}$ may cause methemoglobinemia (blue-baby syndrome) in infants. This condition restricts the oxygencarrying capacity of the blood and may be fatal. Accordingly, a Maximum Contaminant Level (MCL) of $10 \mathrm{mg} / \mathrm{L}$ has been established for Kansas drinking water (Kansas Department of Health and Environment, 2001). An MCL is the highest permissible level (on an annual basis) of a contaminant in water that is delivered to any user of a public-water system. Sources of nitrate in the Cheney Reservoir watershed include manure from pastured or confined animal-feeding operations and wildlife populations, application of synthetic fertilizers, discharged human waste, and atmospheric contributions.

Nitrite plus nitrate concentrations in water from the inflow site ranged from less than 0.02 to $2.4 \mathrm{mg} / \mathrm{L}$, and from less than 0.02 to $0.36 \mathrm{mg} / \mathrm{L}$ in water from the reservoir site. Nitrite was detected infrequently in the well-oxygenated (see dissolved oxygen, table 4) water samples collected during the study described in this report, and when detected, concentrations typically were small relative to nitrate concentrations. No concentrations of nitrate exceeded established water-quality criterion. The mean nitrate concentration in water from the inflow site $(0.78 \mathrm{mg} / \mathrm{L})$ did exceed the stream-water-quality goal for baseflow conditions $(0.25 \mathrm{mg} / \mathrm{L}$, table 1$)$, but these samples were collected during a range of hydrologic conditions, not only base flow.

Total phosphorus concentrations in water from the inflow site ranged from less than 0.03 to $1.8 \mathrm{mg} / \mathrm{L}$ and ranged from less than 0.03 to $0.15 \mathrm{mg} / \mathrm{L}$ in water from the reservoir site (table 4 ). Mean total phosphorus concentrations were $0.33 \mathrm{mg} / \mathrm{L}$ in water from the inflow site and $0.07 \mathrm{mg} / \mathrm{L}$ in water from the reservoir site. The proposed USEPA guideline for Ecoregion $\mathrm{V}$ for total phosphorus in streams and rivers is $0.07 \mathrm{mg} / \mathrm{L}$ and $0.03 \mathrm{mg} / \mathrm{L}$ for lakes and reservoirs (U.S. Environmental Protection Agency, 2001a, 2001b). Mean total phosphorus concentrations in water from the inflow and reservoir sites exceeded the proposed USEPA guideline for Ecoregion V. Mean total phosphorus concentrations in water from the inflow site also exceeded mean stream-water-quality goals for long-term streamflow conditions $(0.10 \mathrm{mg} / \mathrm{L})$ established by the Cheney Reservoir Task Force (table 1).

Because of public-health concerns associated with fecal contamination of surface water, KDHE has (through 2003) a single-sample water-quality criterion of $2,000 \mathrm{col} / 100 \mathrm{~mL}$ (colonies per 100 milliliters of water) of fecal coliform bacteria for noncontact recreational activities and contact recreational activities from November 1 to March 31 (Kansas Department of
Health and Environment, 2001). Noncontact recreational activities are activities in which ingestion of surface water is not probable and include wading, fishing, hunting, and boating. The North Fork Ninnescah River has been classified for noncontact recreation. However, Cheney Reservoir has been classified for contact recreation, where ingestion of surface water is possible in activities such as swimming and water skiing, and is subject to a water-quality criterion of $200 \mathrm{col} / 100 \mathrm{~mL}$ as a geometric mean of five consecutive samples collected in separate 24-hour periods during a 30-day period between April 1 and October 31 of each year (Kansas Department of Health and Environment, 2001).

Fecal coliform bacteria densities in water from the inflow site ranged from less than 4 to $65,000 \mathrm{col} / 100 \mathrm{~mL}$ of sample (colonies per 100 milliliters) and from less than 1 to

$110 \mathrm{col} / 100 \mathrm{~mL}$ in water from the reservoir site (table 4). Mean fecal coliform densities were 4,300 col/100 mL in water from the inflow site and $9.4 \mathrm{col} / 100 \mathrm{~mL}$ in water from the reservoir site. Mean fecal coliform bacteria densities in water from the inflow site exceeded the State of Kansas primary contact and secondary contact recreation criterion of 200 and 2,000 col/100 $\mathrm{mL}$ of sample, respectively (Kansas Department of Health and Environment, 2001). However, as noted previously, State of Kansas primary contact criterion $(200 \mathrm{col} / 100 \mathrm{~mL})$ required a geometric mean of at least five samples collected during separate 24-hour periods within a 30-day period, and samples for this study were not collected at that frequency.

\section{Physical Properties, Solids, and Sediment}

Excessive transport of solids/sediment into a reservoir can shorten the useful life of the reservoir through loss of storage capacity, smothering of rooted vegetation, and adversely affecting benthic (bottom-dwelling) organisms. Solids/sediment in water can absorb, reflect, and scatter solar radiation and increase water temperatures, which may stress aquatic organisms and create conditions favorable to disease in fish populations. Excessive concentrations of solids/sediment in reservoir water increase turbidity, decrease the sunlight that reaches aquatic plants and organisms, and, as a result, may inhibit photosynthesis and primary productivity and favor low-light organisms such as taste-and-odor-producing cyanobacteria. Large concentrations of solids are also a concern because nutrients, which also favor cyanobacteria, often are associated with solids.

TSS represents the suspended solid material in water samples and may consist of organic or inorganic materials originating from sources such as algae, decaying vegetation, solids discharged by industries and municipalities, urban and agricultural runoff, and physical degradation of geologic formations (Mays, 1996). TSS and SSC differ in that TSS is a measure of the dry weight of organic and inorganic solids filtered from a subsample of the original sample. SSC is the measure of the dry weight of the inorganic sediment in the full sample volume of a watersediment mixture (Gray and others, 2000). 
Solids are a concern because they can cause light limitation. High turbidity, sediment, and TSS values at the inflow site are important because of the potential for light limitation in the reservoir. This is of particular concern in Cheney Reservoir due to erodible soils in the watershed. The relation between SSC and sediment-related constituents at the inflow site is examined in table 5.

Possibly because of settling and the effects of algae, the relation between SSC and sediment-related constituents is not as strong at the reservoir site as at the inflow site. However, SSC can be important to understanding algal production in Cheney Reservoir. Although solid particles are related statistically to total nitrogen and phosphorus, which contribute to algal growth, they also can inhibit algal growth by limiting light penetration.

TSS concentrations in water from the inflow site ranged from 8.4 to $1,700 \mathrm{mg} / \mathrm{L}$, and from less than 4.0 (the MDL) to $12 \mathrm{mg} / \mathrm{L}$ in water from the reservoir site (table 4). In comparison, SSC ranged from 22 to $2,150 \mathrm{mg} / \mathrm{L}$ in water from the inflow site and from 2.6 to $25 \mathrm{mg} / \mathrm{L}$ in water from the reservoir site. The differences between concentration ranges and mean concentrations of TSS and SSC may be due to the number of samples collected and analyzed, the range in hydrologic conditions sampled, or, most likely, differences in analytical methods as previously discussed.

The orders-of-magnitude differences in concentrations of TSS and SSC between the inflow and reservoir sites likely are due to the sediment settling in Cheney Reservoir. Pope and others (2002) estimated a sediment-trapping efficiency of 99 percent for Cheney Reservoir. Mau (2001) estimated total sediment deposition of 7,100 acre-ft (or 27 percent of the conservation pool) for Cheney Reservoir since the impoundment of the reservoir in 1965. Sediment trapping efficiency is an important issue because sediment usually acts as a sink for phosphorus. However, stratification, changing water levels, or high winds may cause sediment to act as a source, releasing phosphorus into the water column, further stimulating algal growth.

\section{Dissolved Solids and Major lons}

Dissolved solids are an important chemical indicator of water quality, and in uncontaminated surface water, are the result of natural dissolution of rocks and minerals. In general, the range in dissolved-solids concentrations was greater at the inflow site than at the reservoir site. The concentrations of dissolved solids and major ions at the inflow site are inversely related to the streamflow rate, whereas the reservoir acts as an integrator of streamflow over time, and therefore, dissolvedsolids concentration is less affected by rapidly changing streamflow conditions at the reservoir site.

Sodium concentrations at the inflow site and in Cheney Reservoir are relatively high compared to the North American average in river water of approximately $9 \mathrm{mg} / \mathrm{L}$ (Wetzel, 2001, p. 170). The high sodium concentrations probably are the result of seepage of ground water affected by the Salt Plain Formation or the "Ninnescah salt" in the Ninnescah Shale, which underlie the south-central part of the study area (Gillespie and Hargadine, 1994). When other carbon sources are depleted, cyanobacteria actively transport bicarbonate into cells for use as an alternate source, a process that is unique to cyanobacteria and requires millimolar concentrations of sodium. Thus, the relatively high sodium concentrations in the reservoir may impart an advantage to cyanobacteria, particularly when coupled with increased phosphorus and decreased light (Wetzel, 2001, p. 181).

\section{Nitrogen and Phosphorus}

Nutrients, particularly nitrogen and phosphorus, have been identified as a major reason why much of the Nation's surface water is considered degraded with respect to water quality (U.S. Environmental Protection Agency, 2000). Nutrients also are important in taste-and-odor occurrences. Nitrogen and phosphorus can affect the trophic conditions or degree of biological activity. Nutrient enrichment (eutrophication) can lead to

Table 5. Regression equations showing relation between suspended-sediment concentration and total suspended solids, nutrients, and bacteria in the North Fork Ninnescah River above Cheney Reservoir, south-central Kansas, 1999-2003.

[The explanatory variable, suspended-sediment concentration, ranged from 22 to 2,150 milligrams per liter (mg/L). n, number of samples; MSE, mean square error; $\mathrm{R}^{2}$, coefficient of determination; TSS, total suspended solids; SSC, suspended-sediment concentration; TKN, total Kjeldahl nitrogen; $\mathrm{TN}$, total nitrogen; TP, total phosphorus; col/100 mL, colonies per 100 milliliters; FCB, fecal coliform bacteria]

\begin{tabular}{lllrrr}
\hline \multicolumn{1}{c}{ Constituent } & \multicolumn{1}{c}{ Equation } & $\mathrm{n}$ & $\mathrm{MSE}$ & $\mathrm{R}^{2}$ & $\begin{array}{c}\text { Duan's bias } \\
\text { correction factor }\end{array}$ \\
\hline Total suspended solids $(\mathrm{mg} / \mathrm{L})$ & $\log \mathrm{TSS}=0.629 \operatorname{logSSC}+0.674$ & 20 & 0.0375 & 0.826 & 1.085 \\
Total Kjeldahl nitrogen $(\mathrm{mg} / \mathrm{L})$ & $\log \mathrm{TKN}=0.294 \operatorname{logSSC}-0.489$ & 20 & .0231 & .628 & 1.056 \\
Total nitrogen $^{1}(\mathrm{mg} / \mathrm{L})$ & $\log \mathrm{TN}=0.157 \operatorname{logSSC}+0.002$ & 20 & .0157 & .414 & 1.038 \\
Total phosphorus $(\mathrm{mg} / \mathrm{L})$ & $\mathrm{TP}=0.249 \operatorname{logSSC}-0.269$ & 20 & .00702 & .799 & 1.000 \\
Fecal coliform bacteria $(\mathrm{col} / 100$ & $\operatorname{logFCB}=1.41 \operatorname{logSSC}-0.0242$ & 20 & .171 & .840 & 1.600 \\
$\mathrm{~mL}$ & & & & & \\
\hline
\end{tabular}

${ }^{1}$ Calculated as the sum of ammonia plus organic nitrogen and nitrite plus nitrate nitrogen. 
excessive growth of algae, particularly the cyanobacteria, with subsequent geosmin and MIB production and taste-and-odor problems (Chorus and Bartram, 1999).

Nitrogen occurs in several forms-ammonia, nitrite, nitrate, and as part of organic compounds. Most algal species utilize dissolved forms of inorganic nitrogen (Hem, 1992). The form of nitrogen, along with temperature, salinity, and light, may preferentially determine predominant algal species. Nitrate generally favors desirable phytoplankton groups such as green algae and diatoms, whereas ammonia favors cyanobacteria. In addition, some cyanobacteria can fix atmospheric nitrogen and have a competitive advantage under nitrogen-depleted conditions (Blomqvist and others, 1994). Organic nitrogen is not the form of nitrogen readily used by most phytoplankton; however, some micro-algal groups utilize urea. Thus, urea also may play a role in shaping algal community composition (Wetzel, 2001, p. 220).

In most oxygen-rich water bodies, nitrate is the most common ion due to the ease of oxidation of the nitrite ion. Nitrate is the form of nitrogen most easily used by rooted green plants and most algae and usually occurs in relatively small concentrations in uncontaminated surface water with a world average of $0.30 \mathrm{mg} / \mathrm{L}$ (Reid and Wood, 1976, p. 235). Larger concentrations may stimulate the growth of rooted plants or accelerate algal production to an extent that it may result in taste-and-odor problems in finished drinking water.

Ammonia plus organic nitrogen, also known as total Kjeldahl nitrogen (TKN), is a laboratory test for measuring the amount of organic nitrogen and ammonia in water. It is the sum of ammonia plus organic nitrogen; however, ammonia concentrations typically were small at the inflow and reservoir sites, and therefore, the TKN results are mostly organic nitrogen. TKN concentrations were generally larger in water from the inflow site (ranging from 0.34 to $4.4 \mathrm{mg} / \mathrm{L}$ ) than in water from the reservoir site (0.46-1.4 mg/L) (table 4). Solids and sediment also were larger at the inflow site, and TKN often is associated with solids as discussed previously. Organic nitrogen in water may indicate excessive production or organic pollution in the watershed. Animal and human waste, decaying organic matter, and live organic material like algal cells can cause organic nitrogen enrichment of reservoir water (Tippecanoe Environmental Lake and Watershed Foundation, 2004).

Previous studies have indicated that phosphorus is a primary chemical of concern (Christensen and Pope, 1997;

Pope, 1998; Pope and Milligan, 2000; Mau, 2001; Milligan and Pope, 2001; Smith and others, 2001; Pope and Milligan, 2002; Pope and others, 2002) that may limit the useful life of Cheney Reservoir by increasing its trophic state. Phosphorus availability generally is believed to be the limiting nutrient determining the rate of production (Hem, 1992), and phosphorus is likely the limiting factor in most freshwater systems (Saadoun and others, 2001). Rooted aquatic plants may take up phosphorus held in bottom sediment and subsequently release the phosphorus into the aquatic environment (Mitchell and Stapp, 1996). Sources of phosphorus in the Cheney Reservoir watershed include inorganic phosphates added to agricultural soils as fertilizer, manure from animal production, treated human sewage, and natural runoff from soils.

Orthophosphorus (soluble inorganic phosphorus) is a very small part of total phosphorus. However, it is readily available for uptake by plants and algae. Orthophosphorus concentrations in water at the inflow site ranged from less than 0.01 to $0.45 \mathrm{mg} / \mathrm{L}$. Concentrations in water at the reservoir site ranged from less than 0.01 to $0.09 \mathrm{mg} / \mathrm{L}$. The smaller concentrations in the reservoir likely are due to a combination of biological uptake, settling, and dilution.

\section{Chlorophyll, Geosmin, and Phytoplankton Characteristics of Cheney Reservoir}

Chlorophyll is a colored photosynthetic pigment that occurs in all plants, including phytoplankton, and absorbs light energy (Coleman and Dewar, 1997). It is used as an estimate of phytoplankton biomass. During photosynthesis, carbohydrates are formed from water and carbon dioxide through sunlight energy gathered by chlorophyll. Chlorophyll fluoresces when irradiated with light of a particular wavelength $(440 \mathrm{~nm})$, emiting light of a higher wavelength (665 nm) (YSI, 2005). Therefore, in this study, the fluorescence sensor on the water-quality monitor was installed with the expectation that the monitor would be a surrogate for chlorophyll. However, a comparison of chlorophyll- $a$ analyzed using HPLC and the values from the fluorescence probe had no evident relation (fig. 2). This is consistent with the findings of Mau and others (2004, p. 7), who examined the relation between chlorophyll- $a$ and a fluorescence sensor at Lake Olathe in northeastern Kansas. The lack of a relation may be due to chlorophyll- $b$ and pheophyton, which contribute to in-situ fluorescence and were not measured by HPLC.

One of the problems may be that the fluorescence sensor used in Cheney Reservoir exhibits diurnal fluctuations. Solar energy changes throughout the day, peaking in the early afternoon and declining to nothing during the hours of darkness. However, the diurnal cycles in fluorescence are opposite of the solar energy cycle, declining in the afternoon hours and peaking during the hours of darkness, with as much as a four-fold change in a 24-hour period. The manufacturer of the sensor (YSI, 2005) explains that during periods of high photosynthetic activity, the active chlorophyll is bound in the cells of the organism and is virtually hidden from the sensor. When photosynthesis slows down, the chlorophyll is less active and thus can be detected by the sensor. Using data that changes diurnally also can cause difficulty when developing regression-based models.

Chlorophyll- $a$ was detected in all 34 samples collected from Cheney Reservoir and ranged from 0.53 to $26 \mu \mathrm{g} / \mathrm{L}$ (table 4). Chlorophyll concentrations did not follow a predictable seasonal pattern, and peaks occurred throughout the year. The mean concentration during this study was $7.4 \mu \mathrm{g} / \mathrm{L}$. The mean concentration reported by Smith and others $(2001,2002)$ during 1999-2000 was $8.63 \mu \mathrm{g} / \mathrm{L}$.

Phytoplankton are algae that consist of diverse assemblages of small plants or photosynthetic bacteria (Wetzel, 2001, 


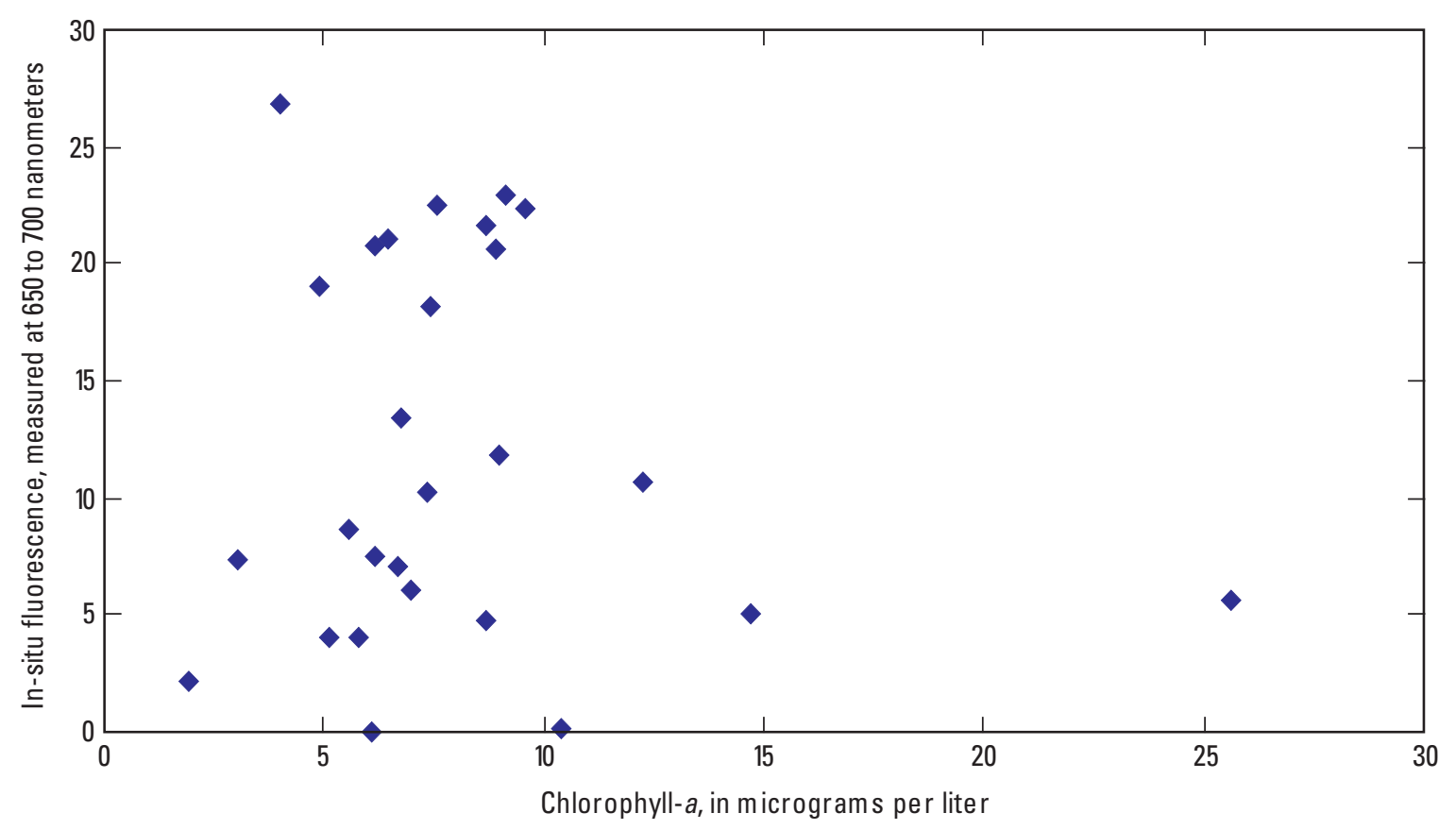

Figure 2. Comparison of laboratory-analyzed chlorophyll-a concentration and in-situ fluorescence in Cheney Reservoir, 2001-03.

p. 332). Phytoplankton growth depends on several important factors including nutrient availability, light, temperature, competition with other organisms, and grazing by zooplankton. In temperate lakes and reservoirs, algal blooms in late summer often consist of cyanobacteria. Cyanobacteria belong to a planktonic group that were classified previously as blue-green algae, but in fact are true bacteria (Wetzel, 2001, p. 332-333; Scott, 2002). However, cyanobacteria contain chlorophyll- $a$, unlike other bacteria. Therefore, although they have a bacteria structure, they are able to photosynthesize like aquatic plants and algae.

Many taste-and-odor occurrences can be linked to cyanobacterial production of geosmin and MIB (Mueller and Ruddy, 1993; Suffet and others, 1999; Saadoun and others, 2001; Ho and others, 2002). In particular, the cyanobacterial genera Anabaena and Oscillatoria are linked to production of geosmin and MIB. Geosmin and MIB also are produced by a group of filamentous bacteria called actinomycetes (Sugiura and others, 1998). Actinomycetes analysis was not part of this study; however, Smith and others (2001) noted that cyanobacteria, not actinomycetes, were the likely cause of tastes and odors in water from Cheney Reservoir. Table 8 (in the "Supplemental Information" at the back of this report) lists the results of algal sampling in Cheney Reservoir. Geosmin concentrations ranged from less than 0.003 to $0.113 \mu \mathrm{g} / \mathrm{L}$, and geosmin was detected in 23 to 25 samples collected from Cheney Reservoir. MIB concentrations ranged from less than 0.005 to $0.011 \mu \mathrm{g} / \mathrm{L}$, and MIB was detected in 6 of 25 samples.

Bacillariophyta (diatoms), chlorophyta (green algae), cryptophyta (cryptomonads), and cyanobacteria (blue-green algae) were the most abundant phytoplankton groups in Cheney
Reservoir. Geosmin concentration also is presented in figure 3 for comparison to percentage of each species to total biovolume. There does not appear to be an obvious relation between the concentration of geosmin and any individual phytoplankton species when expressed as a percentage of total biovolume. Because geosmin production varies among strains of the same species, this lack of relation is expected. The cyanobacterial genus Anabaena is known to contain geosmin-producing strains. With two exceptions, Anabaena was always present when geosmin was detected and is likely one of the cyanobacterial genera responsible for taste-and-odor occurrences in Cheney Reservoir. Other cyanobacteria with the potential for taste-and-odor production occassionally were present and included Oscillatoria and Pseudanabaena. On August 7, 2002, and on March 14, 2003, no geosmin producers were detected in the phytoplankton. However, geosmin was detected, indicating that actinomycetes may have produced geosmin at these times.

Microcystin is one of the most common cyanotoxins (Graham, 2004). Microcystin is produced by numerous species of cyanobacteria and is highly variable both spatially and temporally (Graham, 2004). In Cheney Reservoir, 15 samples were collected for microcystin analysis between January and July 2003. Microcystin was detected in all 15 samples and ranged from 0.1 to $2.0 \mu \mathrm{g} / \mathrm{L}$ (table 4 ). Microcystin concentrations in Cheney Reservoir met or exceeded the World Health Organization guideline of $1 \mu \mathrm{g} / \mathrm{L}$ for finished drinking water in 3 of 15 samples but were never outside the low risk range (0$10 \mu \mathrm{g} / \mathrm{L}$ ) for recreational exposure (Chorus and Bartram, 1999). Species of the genus Microcystis, a common microcystin producer, also were detected during phytoplankton analysis in 7 of 


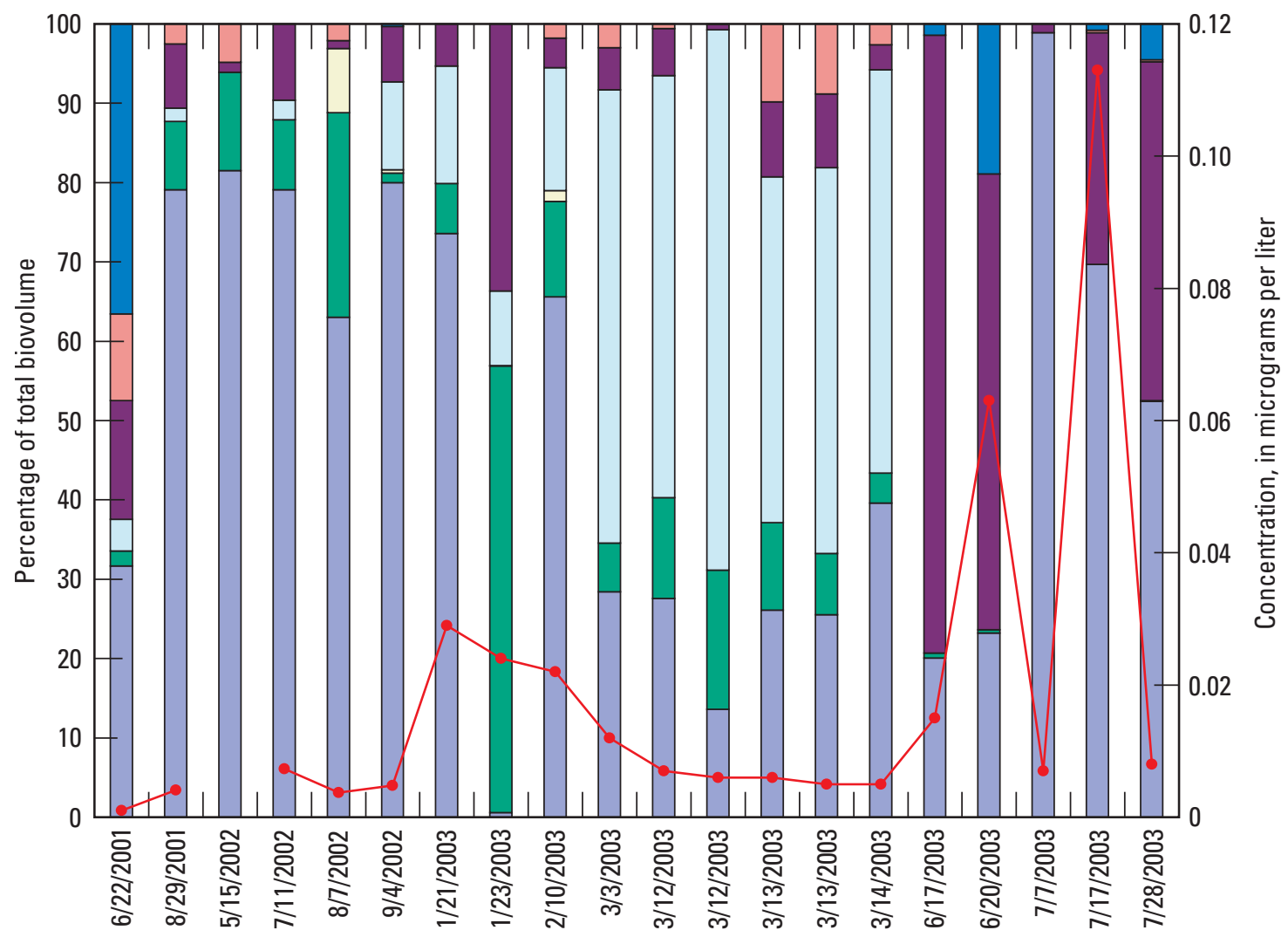

Date sample collected (month/day/year)

\section{EXPLANATION}

$\begin{array}{ll}\square \text { Bacillariophyta } & \square \text { Cyanobacteria } \\ \square \text { Chlorophyta } & \square \text { Euglenophyta } \\ \square \text { Chrysophyta } & \square \text { Pyrrhophyta } \\ \square \text { Cryptophyta } & \longrightarrow \text { Geosmin }\end{array}$

Figure 3. Percentage of total phytoplankton biovolume and geosmin concentration in Cheney Reservoir, 2001-03.

20 samples collected from 2001 through 2003 (table 8, "Supplemental Information" section). Other microcystin producers detected were species of Anabaena (18 of 20 samples) and species of Oscillatoria ( 9 of 20 samples).

\section{Trophic State of Cheney Reservoir and Relation of Nutrients to Compounds Linked to Taste and Odor}

Federal requirements for "fishable" and "swimmable" water have resulted in numerous efforts to classify a lake or reservoir's trophic state (Carlson and Simpson, 1996). Trophic state is the degree of nutrient enrichment and productivity in a body of water. Nutrient and chlorophyll- $a$ concentration data along with transparency measurements typically are used in these classification systems. Trophic state indices (TSIs) were computed using equations developed by Carlson (1977). The indices can be computed from measurements of Secchi-depth transparency or results of analyses for chlorophyll- $a$ or total phosphorus. Carlson's index is a numeric scale that represents the amount of algal biomass in surface water, and the range of the index is approximately 0-100 (but, theoretically, the index has no upper limit). Each 10-unit increment in the scale represents a doubling of algal biomass in surface water. The higher the TSI indices in a lake or reservoir, the more algal biomass is present and the more productive the lake becomes.

The importance of TSI is that it is a simple numeric scale that can be related to the traditional typological scheme originally suggested by Naumann (1919). Unlike the typologic index, Carlson's index represents a continuum of trophic state and not simply discrete lake types (oligotrophic, mesotrophic, eutrophic, and hypereutrophic). Oligotropic is the least productive and nutrient enriched, and hypereutrophic is the most productive and nutrient enriched. The continuum may be more useful for assessing the change of lake trophic state through time than a typological scheme (Christensen and others, 2004).

TSI calculations can be based on chlorophyll- $a$ (TSI$\mathrm{CHY}$ ), total phosphorus (TSI-TP), or secchi disk transparency. 
TSI calculations for this study are based on chlorophyll- $a$ and total phosphorus results (table 6). Chlorophyll- $a$ is considered a better indicator of algal biomass because this variable is the most accurate of the three TSI components at predicting algal biomass (Carlson, 1983). The TSI-TP classification also is provided and is useful for Cheney Reservoir where there are more historical phosphorus data than chlorophyll data.

Trophic indices for Cheney Reservoir that were based on chlorophyll- $a$ concentrations (TSI-CHY) ranged from 47 to 54 during 1999-2003. In contrast, the trophic indices that were based on total phosphorus concentrations (TSI-TP) were higher-from 60 to 72 during the same period. This could be due to the fact that algal biomass is affected by factors other than phosphorus (for example, light availability, nitrogen concentration, and turbidity). Additionally, in many reservoirs the phosphorus probably is sorbed to nonalgal solids and is not available for algal growth (Carlson, 1992).

In Kansas, lake impairment is assessed with a system that uses chlorophyll- $a$ concentrations (Carney, 1998). On the basis of the range of concentrations from 2001-03 (table 4), Cheney Reservoir would be classified as upper mesotrophic (concentration range from 6.0-7.0 $\mu \mathrm{g} / \mathrm{L}$; Carney, 1998) to very eutrophic (concentration range from 20-25 $\mu \mathrm{g} / \mathrm{L}$; Carney, 1998).

However, the mean chlorophyll- $a$ concentration for this study of $7.4 \mu \mathrm{g} / \mathrm{L}$ puts Cheney Reservoir between the upper mesotrophic and slightly eutrophic categories.

Algae need light and nutrients (nitrogen, phosphorus, and various micronutrients) to grow. If light is available and not reflected or absorbed by suspended sediment, algae will continue to grow as long as nutrients are available. Algal growth is nutrient limited when nitrogen, phosphorus, and other nutrients are not available in adequate amounts. Nitrogen-to-phosphorus ratios (N:P) have been used to assess the potential limiting nutrient for algal growth. If a nutrient is limiting, the addition of that nutrient would cause an increase in algal production. In Cheney Reservoir, the mean N:P ratio was 16:1 for 2001-03. Total nitrogen was calculated by adding ammonia plus organic

Table 6. Mean trophic state index (TSI) values for Cheney Reservoir, south-central Kansas, 1999-2003.

[TSI-CHY, trophic state index based on chlorophyll- $a$ concentration; TSI-TP, trophic state index based on total phosphorus concentration]

\begin{tabular}{lcc}
\hline \multicolumn{1}{c}{ Year } & TSI-CHY $^{1}$ & TSI-TP $^{1}$ \\
\hline 1999 & 49 & 72 \\
2000 & 54 & 72 \\
2001 & 47 & 67 \\
2002 & 48 & 71 \\
2003 & 52 & 60 \\
Mean & $\mathbf{5 0}$ & $\mathbf{6 8}$ \\
\hline
\end{tabular}

${ }^{1}$ TSI-CHY and TSI-TP calculations were based on Carlson's (1977) equations. Values for 1999 and 2000 were based on data from Smith and others (2001) for the site nearest the Cheney Reservoir site (fig. 1) used for this report. nitrogen and nitrite plus nitrate concentrations. A ratio of $16: 1$ indicates possible nutrient co-limitation by nitrogen and phosphorus; however, the optimal N:P ratio varies depending on the algal species, and therefore, in a system with many algal species, different species will be limited by different resources, even different nutrients (Wetzel, 2001).

Smith and others (2001) reported a mean N:P ratio of 6:1 for a site near the dam (near the reservoir site used in this study) during 1999-2000. This low N:P ratio indicates potential nitrogen limitation (Smith and others, 2001). The environmental factors limiting algal growth vary both within and among years. Nutrient availability depends on runoff, inflow concentrations, biogeochemical cycling, and algal uptake.

Chlorophyll-to-phosphorus ratios (Chl:TP) that are less than 1 indicate algae are not phosphorus limited (Graham and others, 2004). The Chl:TP ratio in Cheney Reservoir was about 1:4 during the study, suggesting that phosphorus is not limiting. Other factors, including light, may be limiting algal growth in Cheney Reservoir.

To visualize the importance of nitrogen and phosphorus to primary productivity, nitrogen and phosphorus were compared to chlorophyll- $a$ (fig. $4 A, B$ ). The relation between chlorophyll- $a$ and TKN was not statistically significant. Similarly, there was not a statistically significant relation between total phosphorus concentration and chlorophyll- $a$. Orthophosphorus (a bioavailable form of phosphorus) also was compared to chlorophyll- $a$, but this relation also was not statistically significant (and is not shown). The lack of significant relations between chlorophyll- $a$ and nutrients supports the suggestion that other factors, such as light, may limit algal growth in Cheney Reservoir.

Turbidity gives an indication of light limitation (turbidity is a surrogate for suspended sediment; therefore, when turbidity is high, light transmittance is low). To get an idea of light-limiting effects on productivity, concentrations of chlorophyll- $a$ and geosmin, and Anabaena biovolume were compared to turbidity (fig. $5 C, D$, and $E$ ). Only Anabaena biovolume had a significant, positive relation to turbidity. Like most cyanobacteria, Anabaena is adapted to low-light conditions. There were no clear relations between turbidity and geosmin and chlorophyll- $a$ concentrations.

TKN often is associated with solids (or turbidity); however, at Cheney Reservoir this relation is not significant (fig. 5A). To understand the degree to which total phosphorus is associated with the solids phase, total phosphorus and turbidity were plotted (fig. $5 B$ ). Total phosphorus and turbidity often are positively related. In Cheney Reservoir, this relation is statistically significant, with a $\mathrm{R}^{2}$ of 0.59 .

Chlorophyll- $a$ concentrations may indicate increasing cyanobacterial abundance, which may result in elevated geosmin concentrations (fig. 4C). Because MIB concentrations were small or not detected in many samples from Cheney Reservoir, geosmin is the more probable cause of taste-and-odor occurrences during the period of record. For the reservoir site, the relation between chlorophyll- $a$ and geosmin had a 

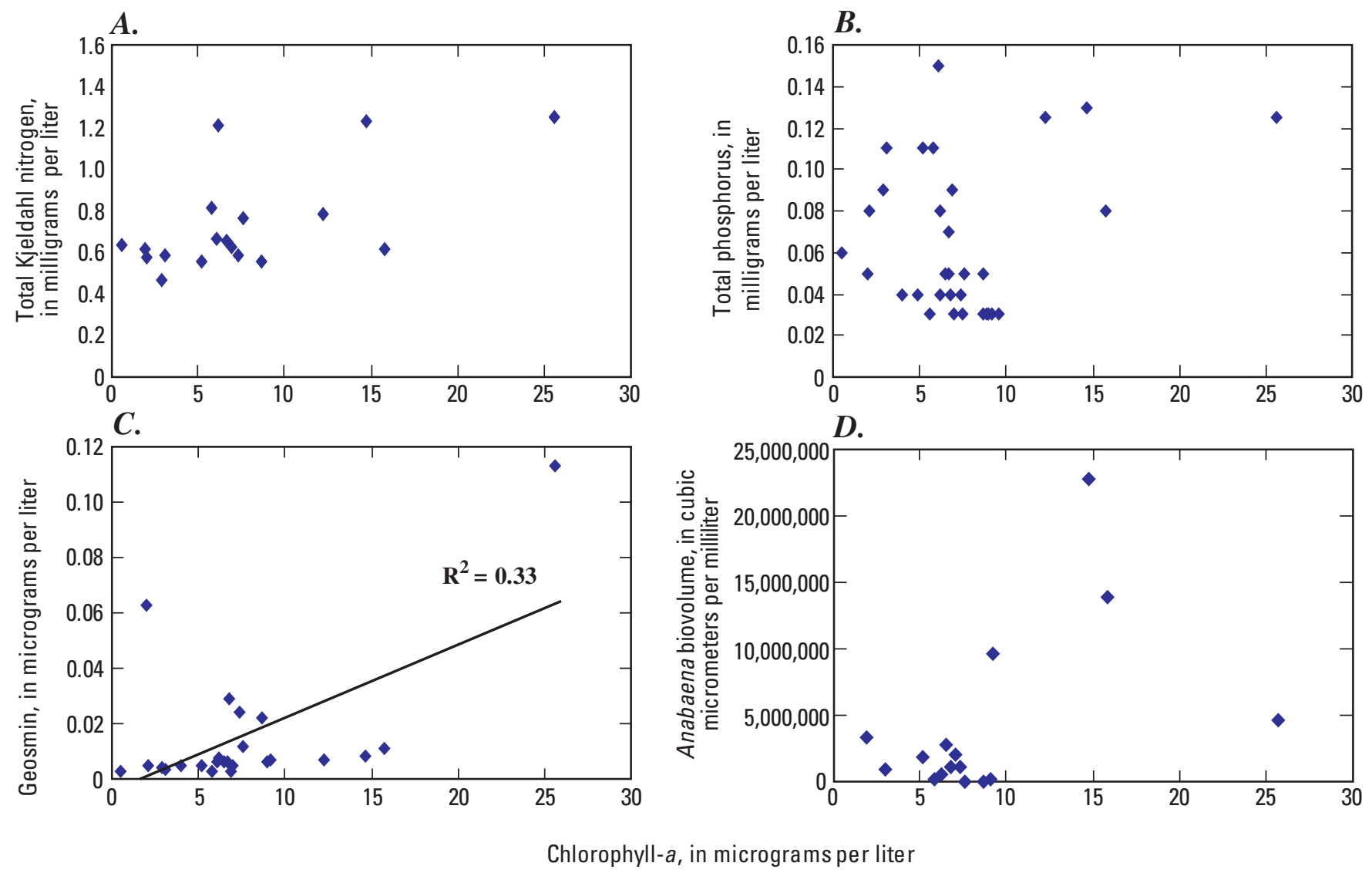

Figure 4. Relation of chlorophyll-a to $(A)$ total Kjeldahl nitrogen, $(B)$ total phosphorus, and $(C)$ geosmin concentrations, and (D) Anabaena biovolume in water from Cheney Reservoir, 2001-03.

$\mathrm{R}^{2}$ of 0.33 ; however, the two outliers may be solely responsible for what statistical significance is displayed in the relation, and therefore, confidence in the validity of the relation is low.

The cyanobacterial genus Anabaena has been associated with taste-and-odor occurrences worldwide (Wetzel, 2001; Smith and others, 2002). Because Anabaena was the dominant cyanobacteria genera in Cheney Reservoir, a comparison was made between Anabaena and other compounds related to taste and odor. Chlorophyll- $a$ concentrations and Anabaena concentrations were not significantly related (fig. 4D). Anabaena concentrations also were not significantly related to total Kjeldahl nitrogen or total phosphorus (fig. $6 A$ and $B$ ). Because Ana-

baena is known to produce geosmin, these two also were compared (fig. $6 C$ ). The lack of a strong statistical relation indicates that Anabanea abundance is not linearly related to geosmin concentrations. Thus, objectionable tastes and odors are not strongly linked to the growth of the genera Anabaena but may be linked to individual strains of Anabaena, other genera, or a combination of cyanobacterial species.

Other potential geosmin producers also were considered for Cheney Reservoir, including gram-positive bacteria and cyanobacteria. Actinomycetes (gram-positive filamentous bacteria) have been linked with taste and odor (Zaitlin and others, 2003). However, this study did not include analysis of actinomycetes. Aphanizomenon (cyanobacteria) has been suggested as a source for geosmin (Wetzel, 2001; Smith and others, 2002); however, it was rarely detected in samples from Cheney Reservoir (one exception was June 17, 2003, when there was a peak in Aphanizomenon biovolume that preceded a peak in geosmin concentration). Oscillatoria (cyanobacteria) also may produce geosmin and was detected in 9 of 20 samples from Cheney Reservoir (see "Supplemental Information" at the back of this report). These nine sample concentrations showed no relation to geosmin $\left(\mathrm{R}^{2}=0.05\right)$. Geosmin also was compared to total cyanobacterial biovolume $\left(\mathrm{R}^{2}=0.20\right)$. The lack of a relation with individual cyanobacteria species may indicate that geosmin is related to a combination of producers and factors. It also is noteworthy that there were only two dates during the study when potential taste-and-odor-producing cyanobacteria were not present in Cheney Reservoir (table 8 at the back of this report).

Finally, Anabaena biovolume (fig. $6 D$ ) was compared to microcystin and showed no significant relation. Potential microcystin producers in Cheney Reservoir include Anabaena, Microcystis, and Oscillatoria (Chorus and Bartram, 1999). Microcystis was infrequently detected (7 of 20 samples), and Oscillatoria had no significant relation to microcystin $\left(\mathrm{R}^{2}=0.27\right)$. As with geosmin, individual strains, other cyanobacteria, or a combination of cyanobacterial species may be producing microcystin. 

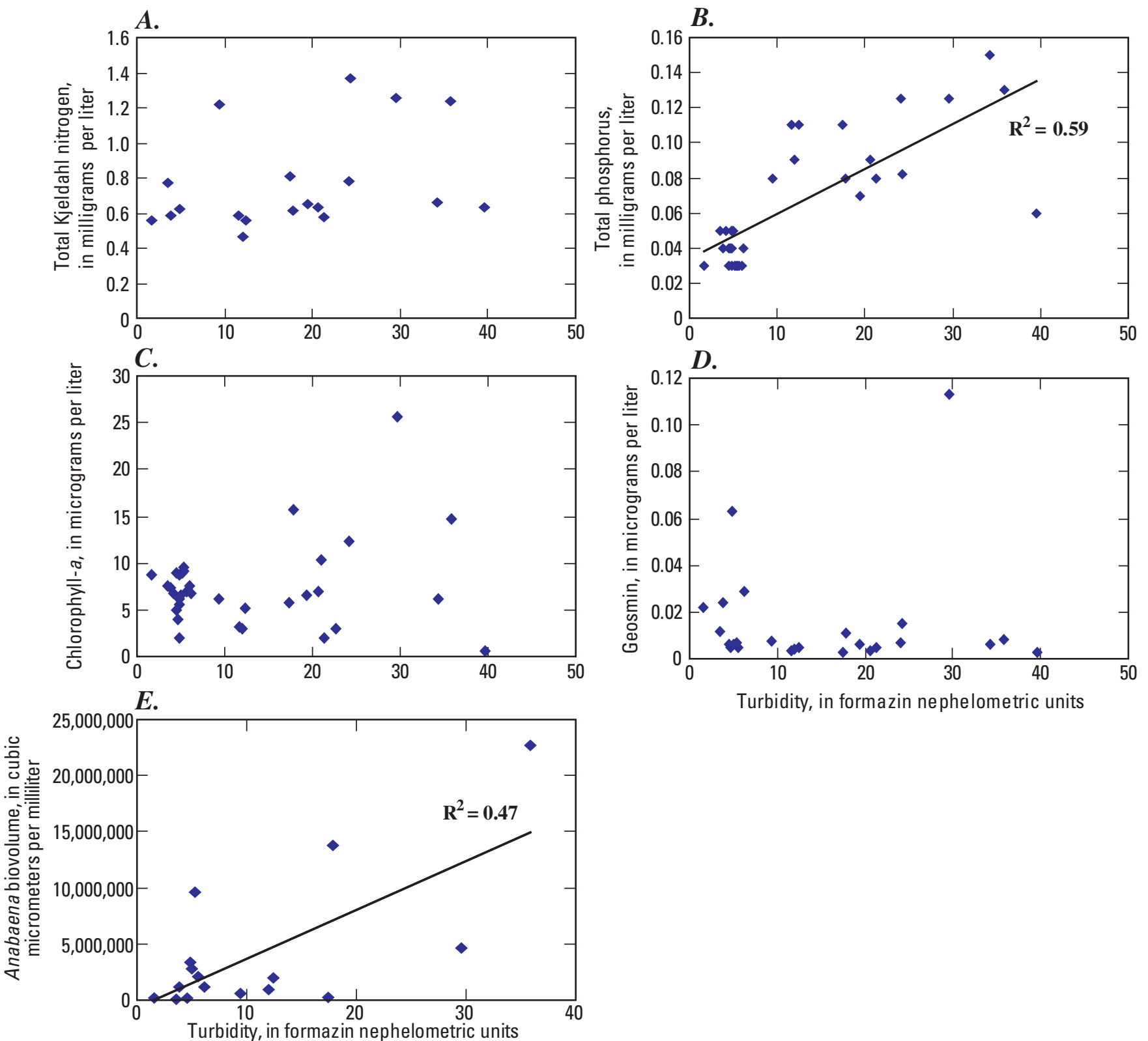

Turbidity, in formazin nephelometric units

Figure 5. Relation of turbidity to $(A)$ total Kjeldahl nitrogen, $(B)$ total phosphorus, $(C)$ chlorophyll-a, and $(D)$ geosmin concentrations, and (E) Anabaena biovolume in water from Cheney Reservoir, 2001-03.

\section{Regression-Estimated Constituent Concentrations and Densities Developed from Water-Quality Monitor Measurements}

Most constituent concentrations and densities are not sampled and analyzed with the frequency needed to estimate tasteand-odor occurrences or to compute accurate loads. Most water-quality constituent concentrations and denstities may change on an hourly basis (refer to http://www.ks.water.usgs.gov/Kansas/rtqw/index.shtml). Therefore, concentrations and densities were estimated on the basis of in-stream and in-lake water-quality monitor measurements and regression analysis. The relation between each analyzed constituent and its surrogate (measurement from the water-quality monitor) is shown in table 7 . The statistical models are site specific and have limitations. In addition to analytical and regression uncertainties, each equation is valid only for the range of data for the constituents used to develop the model. A discussion of those constituents that related to tasteand-odor occurrences follows.

\section{Solids and Sediment}

Both TSS and SSC equations used in subsequent calculations in this report rely on turbidity measurements (table 7) for estimating continuous concentrations. However, TSS and SSC equations developed for the inflow site $\left(R^{2}=0.92\right.$ and 0.85$)$ are 

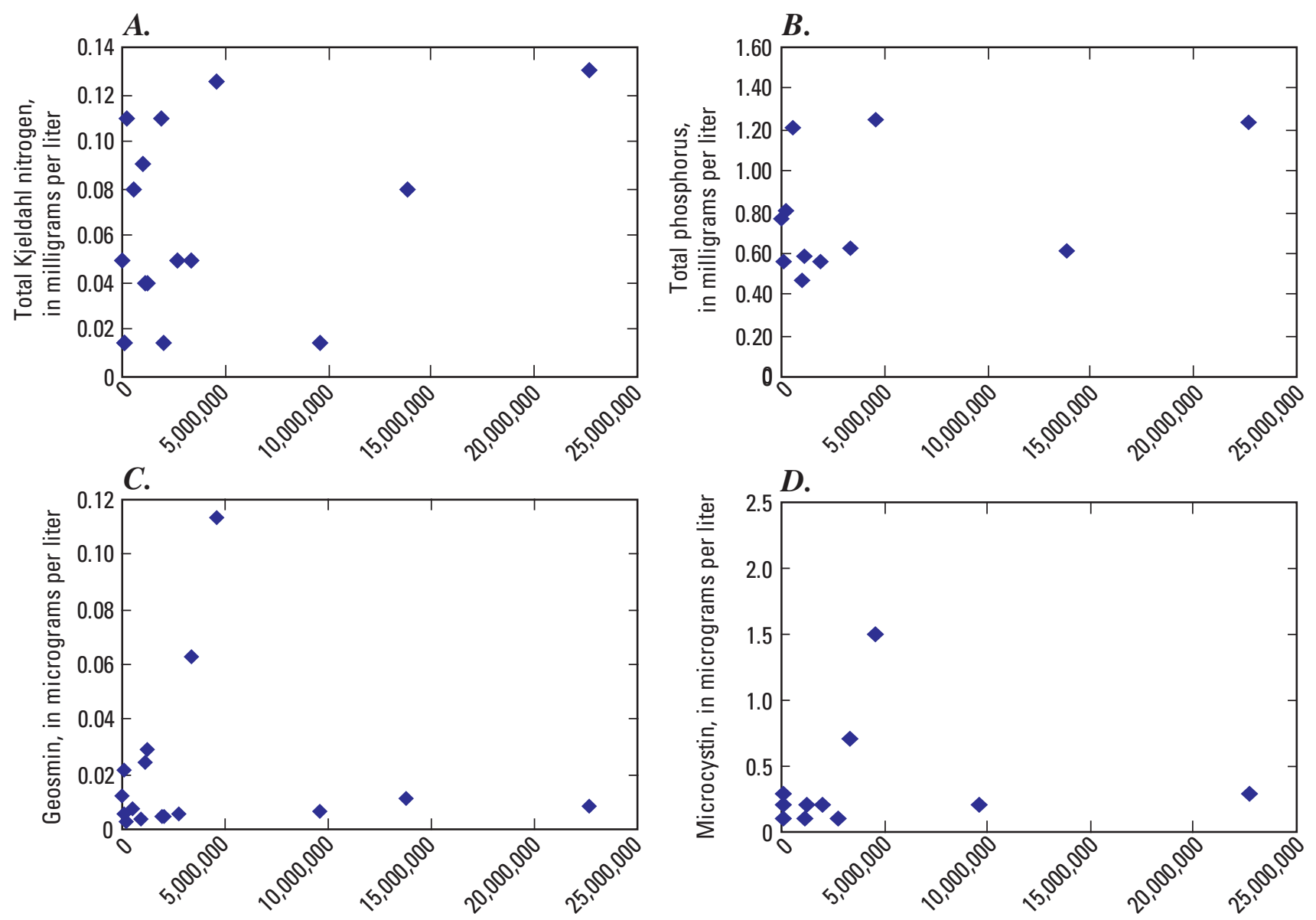

Anabaena biovolume, in cubic micrometers per milliliter

Figure 6. Comparison of Anabaena biovolume to $(A)$ total Kjeldahl nitrogen, $(B)$ total phosphorus, $(C)$ geosmin, and $(D)$ microcystin concentrations in water from Cheney Reservoir, 2001-03.

much better than the equations developed for the reservoir site $\left(\mathrm{R}^{2}=0.42\right.$ and 0.69$)$. Previous studies (Christensen and others, 2002) have demonstrated that turbidity is a better surrogate for TSS and SSC than streamflow. Equations for TSS and SSC that are based on streamflow (for the inflow site) also are provided in table 7. The diagnostic statistics in table 7 (mean square error, MSE, and coefficient of determination, $\mathrm{R}^{2}$ ) indicate that TSS and SSC equations that are based on turbidity are better than those based on streamflow.

\section{Nitrogen and Phosphorus}

An accurate estimate of the inflow of nutrients into Cheney Reservoir would help in understanding the factors that limit algal growth. Both total phosphorus and nitrogen equations use turbidity as an independent variable. Because turbidity is a measure of the amount of particulate matter in water and because organic forms of nitrogen and phosphorus are mostly present in the particulate form, turbidity is positively related to both nutrients (table 7 and figs. $4 A$ and $B$ ). At the inflow site, streamflow was negatively related to TKN but positively related to total phosphorus in the equations. This inconsistency in the direction of the relation between streamflow and the two nutrients may provide some insight as to their source in the watershed. The negative relation with TKN may indicate a point-source-type origin, such as discharge from wastewater treatment facilities and confined animal-feeding operations, or failed septic systems, whereas the positive relation with phosphorus may indicate a nonpoint-source origin such as fertilizer application.

Orthophosphorus is of concern because it is the form of phosphorus that is readily available for algal growth. There was a significant negative relation $\left(\mathrm{R}^{2}\right.$ of 0.835$)$ between orthophosphorus and specific conductance (table 7) at the inflow site, which may indicate that orthophosphorus is associated with runoff (rainfall runoff has a low specific conductance and, thus, has a dilution effect on specific conductance present in base flow). However, 12 of 25 values for orthophosphorus were less than the MDL, which puts the validity of this relation in question. The relation between orthophosphorus and specific conductance is not significant in the reservoir. In Cheney Reservoir, orthophosphorus is significantly related to turbidity 
Table 7. Regression models used to estimate concentrations or densities of selected physical, chemical, and biological properties of water in the North Fork Ninnescah River and Cheney Reservoir, south-central Kansas, 1997-2003.

[n, number of samples; MSE, mean square error; $\mathrm{R}^{2}$, coefficient of determination; TSS, total suspended sediment; mg/L, milligrams per liter; FNU, turbidity, in formazin nephelometric units; Q, streamflow; SSC, suspended-sediment concentration; Alk, alkalinity; SC, specific conductance; Bicarb, bicarbonate; DS, dissolved solids; $\mathrm{Ca}$, calcium; $\mathrm{Mg}$, magnesium; $\mathrm{K}$, potassium; $\mathrm{Na}$, sodium; $\mathrm{Cl}$, chloride; $\mathrm{SO}_{4}$, sulfate; $\mathrm{N}+\mathrm{N}$, nitrite plus nitrate as nitrogen; $\mathrm{DO}$, dissolved oxygen; TKN, total Kjeldahl nitrogen (total ammonia plus organic nitrogen); OP, orthophosphorus; TP, total phosphorus; col/100 mL, colonies per $100 \mathrm{milliliters} \mathrm{of}$ sample; FCB, fecal coliform bacteria; CHY, chlorophyll-a; Ana, Anabaena; WT, water temperature; $\mu \mathrm{g} / \mathrm{L}$, micrograms per liter]

\begin{tabular}{|c|c|c|c|c|c|c|}
\hline Constituent & Equation & $\mathrm{n}$ & $\begin{array}{l}\text { Range of } \\
\text { explanatory } \\
\text { variable(s) }\end{array}$ & MSE & $\mathrm{R}^{2}$ & $\begin{array}{l}\text { Duan's } \\
\text { bias } \\
\text { correc- } \\
\text { tion } \\
\text { factor }\end{array}$ \\
\hline \multicolumn{7}{|c|}{ North Fork Ninnescah River above Cheney (fig. 1) } \\
\hline $\begin{array}{l}\text { Total suspended } \\
\text { solids (mg/L) }\end{array}$ & $\log \mathrm{TSS}=0.893 \log \mathrm{FNU}+0.253$ & 29 & FNU: $14.6-575$ & 0.0233 & 0.923 & 1.064 \\
\hline $\begin{array}{l}\text { Total suspended } \\
\text { solids (mg/L) }\end{array}$ & $\log \mathrm{TSS}=0.682 \log \mathrm{Q}+0.431$ & 29 & Q: $19.5-2,300$ & .119 & .606 & 1.335 \\
\hline $\begin{array}{l}\text { Suspended sedi- } \\
\text { ment }(\mathrm{mg} / \mathrm{L})\end{array}$ & $\operatorname{logSSC}=1.10 \log \mathrm{FNU}+0.0037$ & 22 & FNU: $14.9-575$ & .0589 & .853 & 1.193 \\
\hline $\begin{array}{l}\text { Suspended sedi- } \\
\text { ment }(\mathrm{mg} / \mathrm{L})\end{array}$ & $\log S S C=0.933 \log Q+0.0444$ & 22 & Q: $19.5-2,360$ & .0961 & .760 & 1.260 \\
\hline $\begin{array}{l}\text { Alkalinity }(\mathrm{mg} / \mathrm{L} \\
\left.\text { as } \mathrm{CaCO}_{3}\right)\end{array}$ & $\log \mathrm{Alk}=0.659 \log \mathrm{SC}+0.240$ & 27 & SC: $322-1,250$ & .00377 & .807 & 1.011 \\
\hline $\begin{array}{l}\text { Dissolved solids } \\
(\mathrm{mg} / \mathrm{L})\end{array}$ & $\log \mathrm{DS}=0.910 \log \mathrm{SC}+0.010$ & 127 & SC: $198-1,300$ & .0044 & .872 & 1.011 \\
\hline Calcium (mg/L) & $\log \mathrm{Ca}=0.724 \log \mathrm{SC}-0.386$ & 127 & SC: $198-1,300$ & .0059 & .763 & 1.013 \\
\hline Magnesium (mg/L) & $\mathrm{Mg}=0.0086 \mathrm{SC}+1.68$ & 127 & SC: $198-1,300$ & 1.75 & .799 & 1.000 \\
\hline Sodium (mg/L) & $\log \mathrm{Na}=1.17 \log \mathrm{SC}-1.41$ & 127 & SC: $198-1,300$ & .00614 & .890 & 1.028 \\
\hline Potassium (mg/L) & $\log \mathrm{K}=-0.0003 \mathrm{SC}+0.944$ & 127 & SC: $198-1,300$ & .00841 & .544 & .967 \\
\hline $\begin{array}{l}\text { Bicarbonate } \\
(\mathrm{mg} / \mathrm{L})\end{array}$ & $\log$ Bicarb $=0.669 \log S C+0.296$ & 27 & SC: $322-1,250$ & .0038 & .810 & 1.012 \\
\hline Sulfate (mg/L) & $\log \mathrm{SO}_{4}=0.961 \operatorname{logSC}-1.26$ & 27 & SC: $322-1,250$ & .00585 & .851 & 1.006 \\
\hline Chloride (mg/L) & $\log \mathrm{Cl}=1.37 \log \mathrm{SC}-1.82$ & 27 & SC: $322-1,250$ & .00176 & .975 & .973 \\
\hline $\begin{array}{l}\text { Total Kjeldahl } \\
\text { nitrogen }(\mathrm{mg} / \mathrm{L})\end{array}$ & $\mathrm{TKN}=0.0054 \mathrm{FNU}-0.0004 \mathrm{Q}+0.790$ & 20 & $\begin{array}{l}\text { FNU: } 14.9-532 \\
\text { Q: } 19.5-2,360\end{array}$ & .0728 & .921 & 1.000 \\
\hline $\begin{array}{l}\text { Total phosphorus } \\
(\mathrm{mg} / \mathrm{L})\end{array}$ & $\mathrm{TP}=0.0008 \mathrm{FNU}+0.0001 \mathrm{Q}+0.0863$ & 26 & $\begin{array}{l}\text { FNU: } 7.9-532 \\
\text { Q: } 9.3-2,360\end{array}$ & .00436 & .845 & 1.000 \\
\hline $\begin{array}{l}\text { Orthophosphorus } \\
\text { (mg/L) }\end{array}$ & $\mathrm{OP}=-0.0002 \mathrm{SC}+0.237$ & 25 & SC: $322-1,250$ & .000693 & .835 & 1.000 \\
\hline $\begin{array}{l}\text { Fecal coliform bac- } \\
\text { teria } \\
(\mathrm{col} / 100 \mathrm{~mL})\end{array}$ & $\log \mathrm{FCB}=0.714 \log \mathrm{FNU}-0.0016 \mathrm{SC}+3.10$ & 30 & $\begin{array}{l}\text { FNU: } 7.9-575 \\
\text { SC: } 322-1,250\end{array}$ & .223 & .780 & 1.517 \\
\hline
\end{tabular}


Table 7. Regression models used to estimate concentrations or densities of selected physical, chemical, and biological properties of water in the North Fork Ninnescah River and Cheney Reservoir, south-central Kansas, 1997-2003.-Continued

[n, number of samples; MSE, mean square error; $\mathrm{R}^{2}$, coefficient of determination; TSS, total suspended sediment; mg/L, milligrams per liter; FNU, turbidity, in formazin nephelometric units; Q, streamflow; SSC, suspended-sediment concentration; Alk, alkalinity; SC, specific conductance; Bicarb, bicarbonate; DS, dissolved solids; $\mathrm{Ca}$, calcium; $\mathrm{Mg}$, magnesium; $\mathrm{K}$, potassium; $\mathrm{Na}$, sodium; $\mathrm{Cl}$, chloride; $\mathrm{SO}_{4}$, sulfate; $\mathrm{N}+\mathrm{N}$, nitrite plus nitrate as nitrogen; $\mathrm{DO}$, dissolved oxygen; TKN, total Kjeldahl nitrogen (total ammonia plus organic nitrogen); OP, orthophosphorus; TP, total phosphorus; col/100 mL, colonies per 100 milliliters of sample; FCB, fecal coliform bacteria; CHY, chlorophyll- $a$; Ana, Anabaena; WT, water temperature; $\mu \mathrm{g} / \mathrm{L}$, micrograms per liter]

\begin{tabular}{|c|c|c|c|c|c|c|}
\hline Constituent & Equation & $n$ & $\begin{array}{l}\text { Range of } \\
\text { explanatory } \\
\text { variable(s) }\end{array}$ & MSE & $\mathrm{R}^{2}$ & $\begin{array}{l}\text { Duan's } \\
\text { bias } \\
\text { correc- } \\
\text { tion } \\
\text { factor }\end{array}$ \\
\hline \multicolumn{7}{|c|}{ Cheney Reservoir (fig. 1) } \\
\hline $\begin{array}{l}\text { Total suspended } \\
\text { solids }(\mathrm{mg} / \mathrm{L})\end{array}$ & $\mathrm{TSS}=0.213 \mathrm{FNU}+2.85$ & 19 & FNU: $1.6-40$ & 8.51 & 0.422 & 1.000 \\
\hline $\begin{array}{l}\text { Suspended sedi- } \\
\text { ment }(\mathrm{mg} / \mathrm{L})\end{array}$ & $\operatorname{logSSC}=0.597 \log \mathrm{FNU}+0.361$ & 17 & FNU: $1.6-40$ & .0246 & .688 & 1.054 \\
\hline $\begin{array}{l}\text { Dissolved solids } \\
(\mathrm{mg} / \mathrm{L})\end{array}$ & $\mathrm{DS}=0.550 \mathrm{SC}-8.59$ & 19 & SC: 761-911 & 131 & .811 & 1.000 \\
\hline Sodium (mg/L) & $\mathrm{Na}=0.182 \mathrm{SC}-49.0$ & 19 & SC: 761-911 & 8.34 & .88 & 1.000 \\
\hline Chloride (mg/L) & $\mathrm{Cl}=0.260 \mathrm{SC}-72.4$ & 19 & SC: 761-911 & 78.8 & .613 & 1.000 \\
\hline $\begin{array}{l}\text { Nitrite plus nitrate, } \\
\text { as nitrogen } \\
(\mathrm{mg} / \mathrm{L})\end{array}$ & $\log \mathrm{N}+\mathrm{N}=-2.5 \log \mathrm{DO}+0.709 \log \mathrm{FNU}-0.0014 \mathrm{WT}^{2}+0.979$ & 19 & $\begin{array}{l}\text { DO: } 5.9-17.4 \\
\text { FNU:1.6-40 } \\
\text { WT: } 0.6-27.9\end{array}$ & .104 & .563 & 1.307 \\
\hline $\begin{array}{l}\text { Total Kjeldahl } \\
\text { nitrogen }(\mathrm{mg} / \mathrm{L})\end{array}$ & $\mathrm{TKN}=0.0085 \mathrm{FNU}+0.704 \log \mathrm{DO}+0.658 \mathrm{pH}-5.58$ & 20 & $\begin{array}{l}\text { FNU: } 1.6-40 \\
\text { DO: } 5.9-17.4 \\
\text { pH: } 8.0-9.0\end{array}$ & .033 & .658 & 1.000 \\
\hline $\begin{array}{l}\text { Total phosphorus } \\
(\mathrm{mg} / \mathrm{L})\end{array}$ & $\mathrm{TP}=0.0022 \mathrm{WT}+0.0010 \mathrm{FNU}+0.0218$ & 33 & $\begin{array}{l}\text { WT:: } 0.6-27.9 \\
\text { FNU: } 1.6-40\end{array}$ & .000381 & .765 & 1.000 \\
\hline $\begin{array}{l}\text { Orthophosphorus } \\
\text { (mg/L) }\end{array}$ & $\log \mathrm{OP}=1.01 \log \mathrm{FNU}-2.76$ & 33 & FNU: $1.6-40$ & .122 & .528 & 1.441 \\
\hline Geosmin $(\mu \mathrm{g} / \mathrm{L})$ & $\log \mathrm{Geo}=-1.07 \log \mathrm{FNU}-0.0097 \mathrm{SC}+7.23$ & 18 & $\begin{array}{l}\text { FNU: } 1.6-35.8 \\
\text { SC: } 792-911\end{array}$ & .0473 & .709 & 1.169 \\
\hline $\begin{array}{l}\text { Chlorophyll- } a \\
(\mu \mathrm{g} / \mathrm{L})\end{array}$ & $\log \mathrm{CHY}=0.0145 \mathrm{FNU}+0.987 \log \mathrm{DO}-0.290$ & 26 & $\begin{array}{l}\text { FNU: } 1.6-36 \\
\text { DO: } 5.9-18.2\end{array}$ & .0256 & .488 & 1.061 \\
\hline $\begin{array}{l}\text { Anabaena }(\mathrm{col} / 100 \\
\mathrm{mL})\end{array}$ & Ana $x E^{5}=4.36 \mathrm{FNU}-7.01$ & 16 & FNU: $1.6-35.8$ & 2,200 & .473 & 1.000 \\
\hline
\end{tabular}

(table 7). However, this model also was developed using orthophosphorus values less than the MDL.

\section{Chlorophyll, Geosmin, and Phytoplankton}

Chlorophyll- $a$ analysis was used to provide a measure of the trophic state of Cheney Reservoir. A regression equation relating chlorophyll- $a$ to the properties measured by the waterquality monitor would identify conditions favorable for abundant algae and would be valuable in estimating taste-and-odor occurrences in the reservoir. The equation for the reservoir (table 7) relied on turbidity and dissolved oxygen as explanatory variables. Turbidity may be related to chlorophyll because some of the turbidity is caused by algae (which produce chlorophyll). Dissolved oxygen may be related to chlorophyll because larger concentrations of dissolved oxygen are an expression of photosynthetic activity and possibly the size of the phytoplankton community (and thus larger chlorophyll- $a$ concentrations). Larger phytoplankton populations will have larger chlorophyll concentrations and produce more oxygen as a by-product. In Cheney Reservoir, wind likely helps oxygenate the lake as well. Geosmin concentrations in Cheney Reservoir were negatively related to changes in turbidity and specific conductance. Other real-time water-quality variables known to affect cyanobacterial abundance, including temperature and water residence time, were evaluated, but relations were not significant. These 
relations may reflect the effects of light and nutrients on geosmin concentrations. Cyanobacteria are adapted to low-light conditions as reflected in the positive relation between Anabaena and turbidity (fig. 5); however, the relation between geosmin and turbidity was negative, indicating geosmin concentrations decreased under low-light conditions. Laboratory experiments with Anabaena have also demonstrated that geosmin production decreases with decreased levels of light (Blevins and others, 1995; Saadoun and others, 2001). Cyanobacteria also are adapted to low-nitrogen conditions, and elevated nitrate concentrations may suppress cyanobacterial growth (Blomqvist and others, 1994). Laboratory experiments indicate that geosmin production by Anabaena also is suppressed at large nitrate concentrations (Wu and others, 1991; Saadoun and others, 2001). Nitrate contributes to specific conductance, with decreases resulting in smaller specific conductance. The negative association between geosmin concentrations and specific conductance in Cheney Reservoir may reflect the effect of nitrate on both cyanobacterial growth and geosmin production by cyanobacteria.

\section{Estimated Suspended Solids and Nutrient Inputs to Cheney Reservoir and Comparison to Water-Quality Goals}

Regression-based models for TSS and total phosphorus may be useful for the Cheney Reservoir Task Force in evaluating stream-water-quality goals. Prior to the development of the regression equations, goals could be evaluated only at discrete times during the year when samples were collected. Estimates of TSS and total phosphorus from the North Fork Ninnescah River are particularly important because solids and nutrients are transported from the river to the reservoir and could have a detrimental effect on the water supply. Estimated concentrations for TSS and total phosphorus also may be used to evaluate trends that can be compared to land use, BMPs, and other factors affecting water quality.

Estimated TSS concentrations for 2001-03 were near the base-flow goal (20 mg/L) for stream-water quality (Cheney Reservoir Task Force, written commun., 1996) during much of 2001-03 (fig. $7 B$ ). The long-term goal $(100 \mathrm{mg} / \mathrm{L})$ was exceeded only during periods of runoff, and the runoff goal $(550 \mathrm{mg} / \mathrm{L})$ was exceeded several times during 2001 and 2002. In contrast, the estimated total phosphorus concentration exceeded the base-flow goal $(0.05 \mathrm{mg} / \mathrm{L})$ during the entire time period (fig. $7 C$ ). The estimated total phosphorus concentration was close to the long-term goal $(0.10 \mathrm{mg} / \mathrm{L})$ during periods of base flow, and the runoff goal $(0.40 \mathrm{mg} / \mathrm{L})$ was exceeded several times during 2001 and 2002, and during three high-flow periods in 2003. The exceedance of the total phosphorus and TSS goals at the inflow site is a concern because of the relation of these constituents to taste-and-odor compounds in the reservoir.
Another potential source of phosphorus in Cheney Reservoir is phosphorus flux from sediment. According to Wetzel (2001, p. 281), nutrient inputs to a lake should be associated with biological responses such as phytoplankton biomass (as measured by chlorophyll concentrations). However, researchers have noted that the relation between nutrient inputs and biological responses can be reduced when phosphorus from bottom sediment is considered (Walker and others, 1989; Mueller and Ruddy, 1993). Walker and others (1989) noted that phosphorus released from bottom sediment tended to reduce the effect of hydrologic variability on lake algal production. If the phosphorus flux from bottom sediment is large, there may be little relation between the inflow from North Fork Ninnescah River and algal productivity in Cheney Reservoir. Fisher and others (1995) state that the recycling of nutrients from bottom sediment (internal source) is particularly important in shallow lakes (perhaps due to wind mixing). Internal phosphorus loading from Lake Eucha in northeastern Oklahoma was about 25 percent of the external loading (Haggard and others, 2005).

The oxygen content of overlying lake water strongly affects phosphorus release from bottom sediment. Under anaerobic (absence of oxygen) conditions at the sediment-water interface, phosphorus may be released from reservoir bottom sediment (Alaoui Mhamdi and others, 1994; Istranovics, 1994). In contrast, phosphorus release from the sediment may be greatly suppressed under aerobic (oxygenated) conditions (Erickson and Auer, 1998). Depth profiles of dissolved oxygen concentrations measured in Cheney Reservoir indicate that anaerobic conditions typically do not occur, likely due to strong mixing by wind. Additionally, Gibson (1997) provided evidence that indicated there is a phosphorus-concentration threshold at about $1,000 \mathrm{mg} / \mathrm{kg}$ dry sediment below which sediment tended not to release phosphorus back into the water column. Phosphorus in Cheney Reservoir bottom sediment did not exceed this threshold (Pope, 1998; Mau, 2001).

Near-bottom oxygen and sediment phosphorus concentrations indicate that internal phosphorus loading may not contribute substantially to overall phosphorus concentrations in Cheney Reservoir; however, internal loading of phosphorus has not been evaluated. A complex range of factors affect phosphorus release from bottom sediment (Wetzel, 2001, p. 246), including wind mixing and biological activity. Thus, internal phosphorus loading may be an important source of phosphorus in Cheney Reservoir.

\section{Probability of Taste-and-Odor Occurrences}

Taste-and-odor occurrences in Cheney Reservoir are likely partially related to increases in nutrients entering from the inflow site (North Fork Ninnescah River). However, developing models that relate properties and constituents at the inflow site to taste-and-odor occurrences in the reservoir are beyond the scope of this report. These relations were not obvious at the temporal resolution available for constituents in the reservoir; however, this would be a logical next step for future studies. 

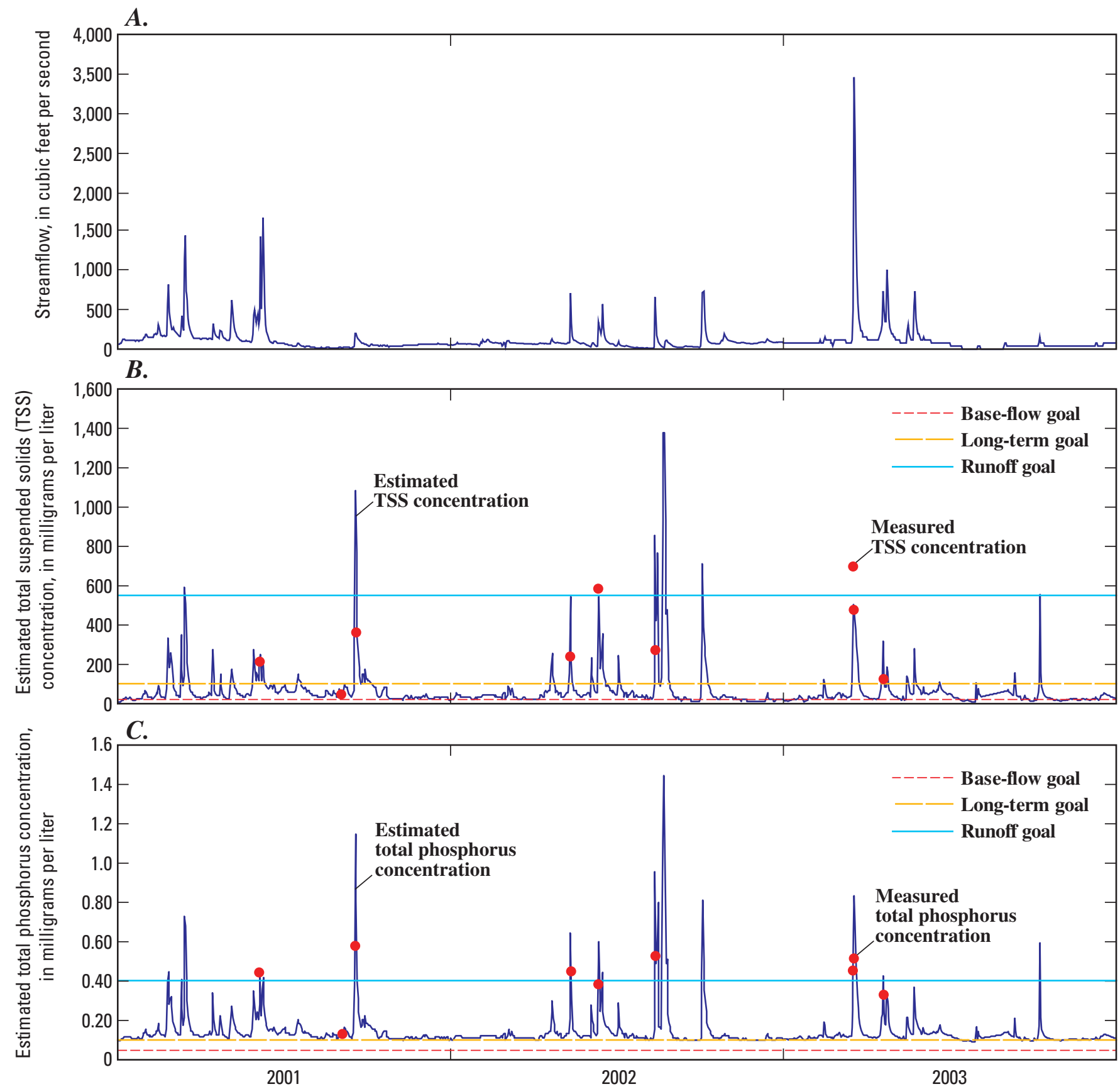

Figure 7. Comparison of $(A)$ streamflow and mean stream-water-quality goals to regression-estimated mean daily $(B)$ total suspended solids and (C) total phosphorus concentrations in water from North Fork Ninnescah River above Cheney Reservoir, 2001-03. Streamwater-quality goals established by Cheney Reservoir Task Force (written commun., 1996). Location of sampling site (site 4) shown in figure 1. 
The compound geosmin is thought to cause many of the taste-and-odor occurrences in Cheney Reservoir (Smith and others, 2002) and is detectable by humans when concentrations exceed $0.01 \mu \mathrm{g} / \mathrm{L}$. The regression equation for estimating geosmin concentrations in Cheney Reservoir (table 7) was applied to the continuous water-quality monitor readings to calculate a continuous estimate of geosmin concentration for 2003 (fig. 8A). For much of 2003, estimated geosmin concentrations were greater than $0.01 \mu \mathrm{g} / \mathrm{L}$.

Continuous estimates of geosmin concentrations can be used to determine the frequency at which concentrations potentially exceed human detection levels. The probability of exceeding (at the 95-percent confidence level) the $0.01-\mu \mathrm{g} / \mathrm{L}$ human detection level can be displayed for each hourly geosmin value. Figure $8 B$ illustrates the probability (as a percentage) that geosmin concentrations exceeded $0.01 \mu \mathrm{g} / \mathrm{L}$. The managers of Wichita's water supply can use probability values to assess water-quality conditions relative to human detection limits or other criteria. These assessments may be used to evaluate BMPs and change water treatment.

Two relatively large geosmin values $(0.06 \mu \mathrm{g} / \mathrm{L}$ on June 20,2003 , and $0.12 \mu \mathrm{g} / \mathrm{L}$ on July 17,2003 , fig. $8 A$ ) were not accurately estimated with the model. More data collection at these larger concentrations could be used to improve the model. Despite the lack of model fit for these two values, a probability of exceedance of 100 percent and about 90 percent (fig. $8 B$ ) were estimated, respectively. This indicates that although an accurate concentration is not determined, the model accurately estimates that the two large values exceed the human detection limit.

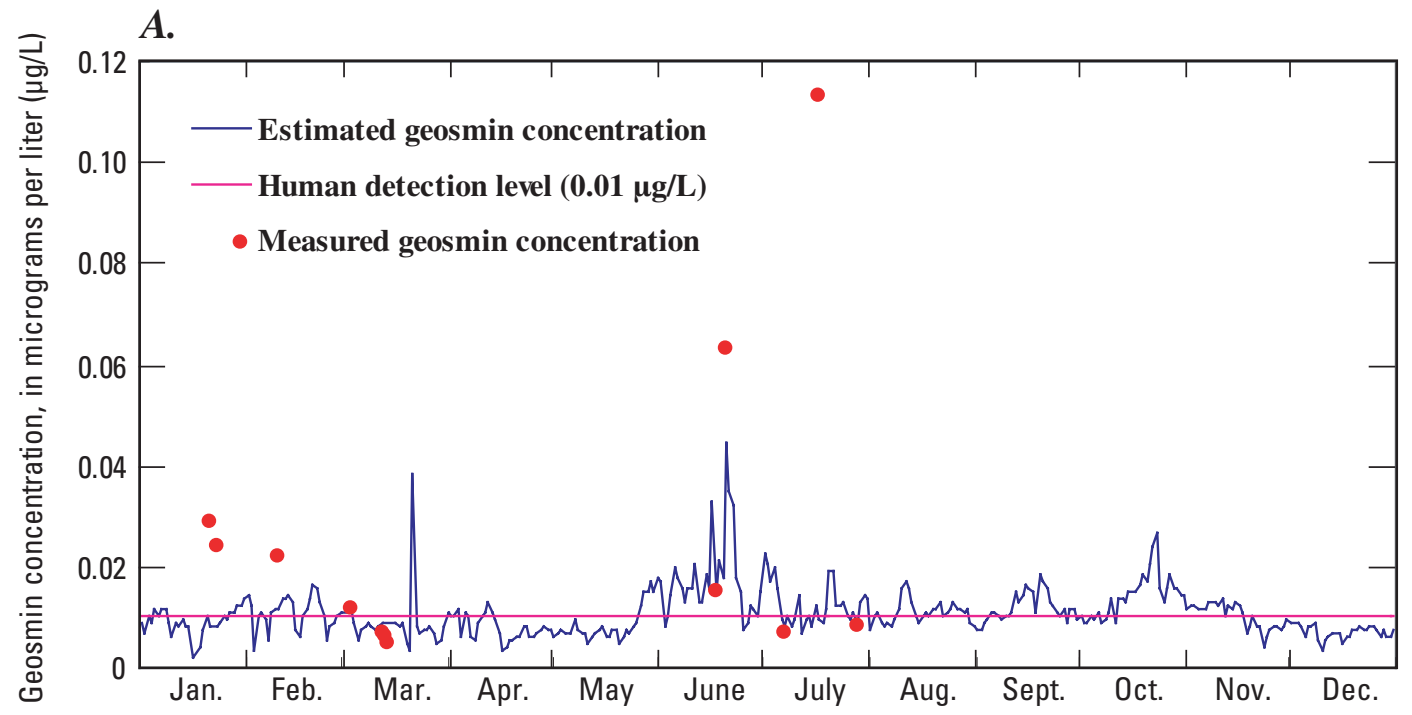

B.

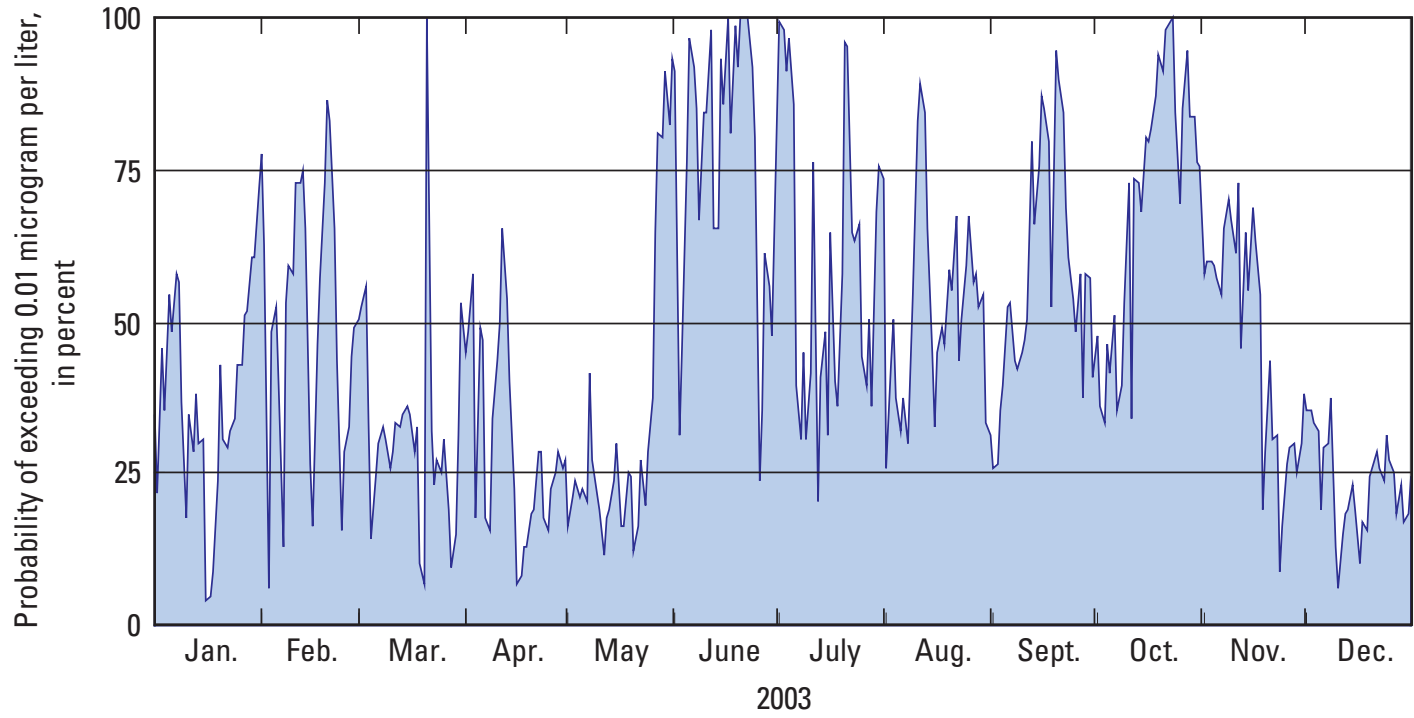

Figure 8. Comparison of $(A)$ measured and regression-estimated geosmin concentrations in water samples from Cheney Reservoir, 2003, and (B) probability of exceeding the human detection level of 0.01 microgram per liter. 


\section{Summary}

Cheney Reservoir in south-central Kansas provides flood control, wildlife habitat, recreational opportunities, and a municipal water supply for the city of Wichita. Objectionable tastes and odors in the water supply are a concern. Therefore, in 1996 the U.S. Geological Survey entered into a cooperative study with the city of Wichita to describe spatial occurrence and transport of selected water-quality constituents in the streams of the Cheney Reservoir watershed and into and out of Cheney Reservoir and to investigate relation to taste-and-odor compounds. Two sites were chosen for analysis in the study described in this report, North Fork Ninnescah River above Cheney Reservoir (the inflow site) and Cheney Reservoir near Cheney Dam (the reservoir site).

Continuously recording water-quality monitors were installed at the inflow and reservoir sites. The monitor at the inflow site was installed in October 1998 and measured physical water-quality properties including specific conductance, $\mathrm{pH}$, water temperature, turbidity, and dissolved oxygen. Streamflow also was measured at the inflow site. The monitor in Cheney Reservoir was installed in March 2001 and measured the same physical properties as the inflow site with the addition of fluorescence. The data from these monitors were made available in real time on the World Wide Web at URL

http://ks.waterdata.usgs.gov/nwis.

In addition to continuous data, water samples were collected from both sites between 1997 and 2003 and analyzed for physical properties, suspended sediment, major ions, nutrients, and bacteria. Additional analysis of samples from the reservoir site included chlorophyll- $a$, geosmin, 2-methylisoborneol (MIB), and phytoplankton analysis.

The sampling plan for this study was intended to investigate the relation of water-quality constituents to taste-and-odor occurrences in the water. It is believed that objectionable tastes and odors result from the degradation of algae. Earthy and musty odors in water commonly are caused by geosmin and MIB, which are produced by certain types of algae and bacteria. MIB, however, was rarely detected in Cheney Reservoir and as a result is not a likely cause of taste-and-odor occurrences during the period of study. Nutrients also are important for tasteand-odor occurrences because they can affect the trophic conditions in a reservoir and excessive amounts can lead to eutrophication (nutrient enrichment). This, in turn, can lead to excessive growth of algae and the production of geosmin, resulting in taste-and-odor occurrences.

Chlorophyll (a colored pigment in plants) in Cheney Reservoir varied substantially. The average chlorophyll- $a$ concentration during this study was $7.4 \mu \mathrm{g} / \mathrm{L}$. Chlorophyll is used as a measure of phytoplankton biomass. Phytoplankton are algae that consist of diverse assemblages of small plants or photosynthetic bacteria. Typically, most of the phytoplankton identified in samples from Cheney Reservoir were bacillariophyta (diatoms), chlorophyta (green algae), cryptophyta (cryptomonads), and cyanobacteria (photosynthetic bacteria). Anabaena, a cyanobacterium often linked to production of geosmin, was the dominant cyanobacterial genera in Cheney Reservoir during the study. However, Anabaena was not strongly related to geosmin in Cheney Reservoir. Therefore, most of the geosmin detected in the water from the reservoir site may have been produced by other cyanobacteria or gram-positive bacteria such as actinomycetes. Alternately, the lack of a strong statistical relation may indicate that Anabaena abundance is not linearly related to geosmin concentration.

Trophic indices that were based on chlorophyll- $a$ concentration for Cheney Reservoir ranged from 47 to 54 during 2001-03. Trophic indices calculated on the basis of total phosphorus concentration were higher, ranging from 60 to 72 for the same period. The difference between the two indices may be due to algal biomass being affected by light availability, nitrogen concentration, and turbidity, in addition to total phosphorus.

Nitrogen to phosphorus ratios (N:P) also were calculated to help understand the role these nutrients play in algal production. In Cheney Reservoir, the N:P ratio was 16:1 for 2001-03, indicating that nutrients may be co-limiting. The chlorophyllto-phosphorus ratio (Chl:TP) was about 1:4, indicating that phosphorus may not be limiting and suggests that other factors, such as light, may be the limiting factor for algal growth.

Large concentrations of total suspended solids may be a concern for taste-and-odor issues because solids are related to nutrients, which contribute to algal growth. The transport of suspended solids and nutrients from the North Fork Ninnescah River to Cheney Reservoir has been monitored since 1997 in an effort to mitigate algal proliferation. Estimated total suspended solids and total phosphorus concentrations in the North Fork Ninnescah River during 2001-03 were compared to Cheney Reservoir Task Force stream-water-quality goals. The longterm goal for total suspended solids was exceeded only during periods of runoff, and the runoff goal was exceeded several times in 2001 and 2002. In contrast, the estimated total phosphorus concentration was close to the long-term goal (exceeding the base-flow goal for all of 2001-03) during periods of base flow, and the runoff goal was exceeded during periods of runoff.

The exceedance of total phosphorus and total suspended solids goals at the inflow site is a concern because of the relation of these constituents to taste-and-odor compounds at the reservoir site. Future studies could design models that use the properties from the inflow site to predict taste-and-odor occurrences in the lake.

To be able to predict taste-and-odor occurrences in Cheney Reservoir, geosmin concentrations and other compounds were estimated using regression analysis and the physical properties measured by the water-quality monitor. Geosmin concentrations in Cheney Reservoir were found to be related to turbidity and specific conductance, perhaps as a result of the effects of light and nutrients. The regression equation for geosmin was applied to the continuous water-quality monitor measurements to calculate continuous estimates of geosmin concentration for 2003. The city of Wichita may be able to use this type of analysis to determine when concentrations of geosmin are likely to be greater than $0.01 \mu \mathrm{g} / \mathrm{L}$, which is the human detection level for geosmin in water. 


\section{References Cited}

Alaoui Mhamdi, M., Aleya, L., Rachig, S., and Devaux, J., 1994, Preliminary study of phosphorus exchange at the sediment-water interface in Al Massira Reservoir (Morocco): Journal of Water Science, v. 7, no. 2, p. 115-130.

Anderson, C.W., 2004, Turbidity, version 2.0, 8/2004: U.S. Geological Survey Techniques of Water-Resources Investigations, book 9, chap. 6.7, $64 \mathrm{p}$.

Bayne, C.K., 1956, Geology and ground-water resources of Reno County, Kansas: Kansas Geological Survey Bulletin 120, 128 p.

Blain, G.T., 2001, The cost of water treatment vs. pollution prevention-the value of water: 18th Annual Water and the Future of Kansas Conference Proceedings, p. 16-19.

Blevins, W.T., Schrader, K.K., and Saadoun, I., 1995, Comparative physiology of geosmin production by Streptomyces halstedii and Anabaena sp.: Water Science and Technology, v. 31, no. 11, p. 127-133.

Blomqvist, P., Petterson, A., and Hyenstrand, P., 1994, Ammonium-nitrogen - a key regulatory factor causing dominance of non-nitrogen-fixing cyanobacteria in aquatic systems: Archiv Fuer Hydrobiologie, v. 132, p. 141-164.

Carlson, R.E., 1977, A trophic state index for lakes: Limnology and Oceanography, v. 22, no. 2, p. 361-369.

Carlson, R.E., 1983, Discussion on "Using differences among Carlson's trophic state in regional water quality assessment," by Richard A. Osgood: Water Resources Bulletin, v. 19, p. 307-309.

Carlson, R.E., 1992, Expanding the trophic state concept to identify non-nutrient limited lakes and reservoirs, in Proceedings of a National Conference on Enhancing the States' Lake Management Programs-Monitoring and Lake Impact Assessment: Chicago, Illinois, p. 59-71.

Carlson, R.E., and Simpson, J., 1996, A coordinator's guide to volunteer lake monitoring methods: North American Lake Management Society, 96 p.

Carmichael, W.W., 2001, Assessment of blue-green algal toxins in raw and finished drinking water: Denver, Colorado, American Water Works Research Foundation and American Water Works Association, ISBN 1583210768, 179 p.

Carney, C.E., 1998, A primer on lake eutrophication and related pollution problems: Kansas Department of Health and Environment, Bureau of Environmental Field Services, 30 p.

Christensen, V.G., 2001, Characterization of surface-water quality based on real-time monitoring and regression analysis, Quivira National Wildlife Refuge, south-central Kansas, December 1998 through June 2001: U.S. Geological Survey Water-Resources Investigations Report 01-4248, 28 p.

Christensen, V.G., Jian, Xiaodong, and Ziegler, A.C., 2000, Regression analysis and real-time water-quality monitoring to estimate constituent concentrations, loads, and yields in the Little Arkansas River, south-central Kansas, 1995-99: U.S. Geological Survey Water-Resources Investigations Report 00-4126, 36 p.
Christensen, V.G., Payne, G.A., and Kallemeyn, L.W., 2004, Effects of changes in reservoir operations on water quality and trophic-state indicators in Voyageurs National Park, northern Minnesota, 2001-03: U.S. Geological Survey Scientific Investigations Report 2004-5044, 42 p.

Christensen, V.G., and Pope, L.M., 1997, Occurrence of dissolved solids, nutrients, atrazine, and fecal coliform bacteria during low flow in the Cheney Reservoir watershed, southcentral Kansas, 1996: U.S. Geological Survey WaterResources Investigations Report 97-4153, 13 p.

Christensen, V.G., Rasmussen, P.P., and Ziegler, A.C., 2002, Comparison of estimated sediment loads using continuous turbidity measurements and regression analysis, in Proceedings of Turbidity and Other Sediment Surrogates Workshop, April 30-May 2, 2002, Reno, Nevada: Subcommittee on Sedimentation, available on the Web, accessed June 4, 2002, at http://water.usgs.gov/osw/techniques/TSS/christensen.pdf

Chorus, I., and Bartram, J., 1999, Toxic cyanobacteria in water-a guide to their public health consequences, monitoring and management: New York, E\&FN Spon, 416 p.

City of Wichita, 2005, Taste and odor questions: City of Wichita, Kansas, available on Web, accessed January 20, 2005, at http://www.wichita.gov/cityoffices/waterandsewer/ watertasteandodorquestions.htm

Clesceri, L.S., Greenberg, A.E., and Eaton, A.D., eds., 1998, Standard methods for the examination of water and wastewater (20th ed.): Baltimore, Maryland, United Book Press, Inc., various pagination.

Cohn, T.A., DeLong, L.L., Gilroy, E.J., Hirsch, R.M., and Wells, D., 1989, Estimating constituent loads: Water Resources Research, v. 25, no. 5, p. 937-942.

Coleman, G.J., and Dewar, David, 1997, The Addison-Wesley science handbook: Ontario, Addison-Wesley Publishers Limited, $281 \mathrm{p}$.

Duan, N., 1983, Smearing estimate - a nonparametric retransformation method: Journal of the American Statistical Association, v. 78, p. 605-610.

Dufour, A.P., 1977, Escherichia coli-the fecal coliform, in Hoadley, A.W., and Dutka, B.J., eds., Bacterial indicators/ health hazards associated with water, 1977: American Society for Testing and Materials, ASTM STP 635, p. 48-58.

Erickson, M.J., and Auer, M.T., 1998, Chemical exchange at the sediment-water interface of Cannonsville Reservoir: Lake and Reservoir Management, v. 14, no. 2-3, p. 266-277.

Fetter, C.W., 1994, Applied hydrogeology (3rd ed.): Englewood Cliffs, New Jersey, Prentice Hall, 691 p.

Fisher, T.R., Melack, J.M., Grobbelaar, J.U., and Howarth, R.W., 1995, Nutrient limitation of phytoplankton and eutrophication of inland, estuarine, and marine waters, in Theissen, Holm, ed., Phosphorus in the global environment: New York, John Wiley and Sons, p. 301-322.

Flahart, R., 2005, Environmental microbiology: Kansas Department of Health and Environment, available on Web, accessed March 8, 2005, at URL http://www.kdhe.state.ks.us/ envmicro 
Gibson, C.E., 1997, The dynamics of phosphorus in freshwater and marine environments, in Tunney, H., Carton, O.T., Brookes, P.C., and Johnston, A.E., eds., Phosphorus loss from soil to water: New York, CAB International, p. 119135.

Gillespie, J.B., and Hargadine, G.D., 1994, Geohydrology and saline ground-water discharge to the South Fork Ninnescah River in Pratt and Kingman Counties, south-central Kansas: U.S. Geological Survey Water-Resources Investigations Report 93-4177, 51 p.

Gilroy, E.J., Hirsch, R.M., and Cohn T.A., 1990, Mean square error of regression-based constituent transport estimates: Water Resource Research, v. 26, no. 9, p. 2069-2077.

Graham, J.L., 2004, Environmental factors influencing microcystin distribution and concentration in Midwestern lakes: Columbia, University of Missouri, PhD dissertation, $109 \mathrm{p}$.

Graham, J.L., Jones, J.R., Jones, S.B., Downing, J.A., and Clevenger, T.E., 2004, Environmental factors influencing microcystin distribution and concentration in the Midwestern United States: Water Research, v. 38, p. 4395-4404.

Gray, J.R., Glysson, G.D., Turcios, L.M., and Schwartz, G.E., 2000, Comparability of suspended-sediment concentration and total suspended solids data: U.S. Geological Survey Water-Resources Investigations Report 00-4191, 14 p.

Haggard, B.E., Moore, P.A., Jr., and DeLaune, P.B., 2005, Phosphorus flux from bottom sediments in Lake Eucha, Oklahoma: Journal of Environmental Quality, v. 34, p. 724 728.

Hansen, C.V., 1991, Estimates of freshwater storage and potential natural recharge for principal aquifers in Kansas: U.S. Geological Survey Water-Resources Investigations Report 87-4230, 100 p.

Helsel, D.R., and Hirsch, R.M., 1992, Statistical methods in water resources: New York, Elsevier, 4th Impression, 522 p.

Hem, J.D., 1992, Study and interpretation of chemical characteristics of natural water ( $3 d$ ed.): U.S. Geological Survey Water-Supply Paper 2254, 263 p.

Hirsch, R.M., Helsel, D.R., Cohn, T.A., and Gilroy, E.J., 1993, Statistical analysis of hydrologic data, in Maidment, D.R., ed., Handbook of hydrology: New York, McGraw-Hill, Inc., p. 17.1-17.55.

Ho, Lionel, Newcombe, Gayle, and Croue, J.P., 2002, Influence of the character of NOM on the ozonation of MIB and geosmin: Water Research, v. 36, p. 511-518.

Horowitz, A.J., Demas, C.R., Fitzgerald, K.K., Miller, T.L., and Rickert, D.A., 1994, U.S. Geological Survey protocol for the collection and processing of surface-water samples for the subsequent determination of inorganic constituents in filtered water: U.S. Geological Survey Open-File Report 94-539, $57 \mathrm{p}$.

Istranovics, V., 1994, Fractional composition, adsorption, and release of sediment phosphorus in the Kis-Balaton Reservoir: Water Research, v., 28, no. 3, p. 717-726.

Kansas Department of Agriculture and U.S. Department of Agriculture, 2004, Kansas farm facts 2003: Topeka, Kansas, various pages.
Kansas Department of Health and Environment, 2001, Kansas register: Topeka, Kansas Secretary of State, v. 20, no. 33, p. $1264-1277$.

Kennedy, E.J., 1983, Computation of continuous records of streamflow: U.S. Geological Survey Techniques of WaterResources Investigations, book 3, chap. A13, 53 p.

Mallevialle, J., and Suffet, I.H., eds., 1987, Identification and treatment of tastes and odors in drinking water: American Water Works Association Research Foundation, 292 p.

Mau, D.P., 2001, Sediment depositional trends and transport of phosphorus and other chemical constituents, Cheney Reservoir watershed, south-central Kansas: U.S. Geological Survey Water-Resources Investigations Report 01-4085, $40 \mathrm{p}$.

Mau, D.P., Ziegler, A.C., Porter, S.D., and Pope, L.M., 2004, Surface-water-quality conditions and relation to taste and odor occurrences in Lake Olathe watershed, northeast Kansas, 2000-02: U.S. Geological Survey Scientific Investigations Report 2004-5047, 95 p.

Mays, L.W., 1996, Water resources handbook: New York, McGraw-Hill Co., various pagination.

McCutcheon, S.C., Martin, J.L., and Barnwell, T.O., Jr. 1993, Water quality, in Maidment, D.R., ed., 1993, Handbook of hydrology: New York, McGraw-Hill, Inc., p. 11.37.

Milligan, C.R., and Pope, L.M., 2001, Occurrence of phosphorus, nitrate, and suspended solids in streams of the Cheney Reservoir watershed, south-central Kansas, 1997-2000: U.S. Geological Survey Water-Resources Investigations Report 01-4199, 22 p.

Mitchell, M.K., and Stapp, W.B., 1996, Field manual for waterquality monitoring - an environmental education program for schools (10th ed.): Dexter, Michigan, Thomson-Shore, Inc., $304 \mathrm{p}$.

Mueller, D.K., and Helsel, D.R., 1996, Nutrients in the Nation's waters - too much of a good thing?: U.S. Geological Survey Circular 1136, 24 p.

Mueller, D.K., and Ruddy, B.C., 1993, Limnological characteristics, nutrient loading and limitation, and potential sources of taste and odor problems in Stanley Lake, Colorado: U.S. Geological Survey Water-Resources Investigations Report 92-4053, 55 p.

Naumann, E.C.L., 1919, Some aspects of the ecology of the limnoplankton, with special references to the phytoplankton: Svensk Botanisk Tidskrift, v. 13, no. 2, p. 129-163.

Ott, R.L., 1993, An introduction to statistical methods and data analysis: Belmont, California, Duxbury Press, 1051 p.

Pepper, I.L., Gerba, C.P., and Brusseau, M.L., eds., 1996, Pollution science: New York, Academic Press, 397 p.

Policy Research Institute, 2004, Kansas statistical abstract: Lawrence, Kansas, University of Kansas, 555 p.

Pope, L.M., 1998, Watershed trend analysis and water-quality assessment using bottom-sediment cores from Cheney Reservoir, south-central Kansas: U.S. Geological Survey WaterResources Investigations Report 98-4227, 24 p. 
Pope, L.M., and Christensen, V.G., 1997, Water-quality study of the Cheney Reservoir watershed, south-central Kansas: U.S. Geological Survey Fact Sheet 104-97, 2 p.

Pope, L.M., and Milligan, C.R., 2000, Preliminary assessment of phosphorus transport in the Cheney Reservoir watershed, south-central Kansas, 1997-98: U.S. Geological Survey Water-Resources Investigations Report 00-4023, 29 p.

Pope, L.M., and Milligan, C.R., 2002, Sources and concentrations of phosphorus in the Cheney Reservoir watershed, south-central Kansas: U.S. Geological Survey Fact Sheet 010-02, $4 \mathrm{p}$.

Pope, L.M., Milligan, C.R., and Mau D.P., 2002, Historical contributions of phosphorus from natural and agricultural sources and implications for stream water quality, Cheney Reservoir watershed, south-central Kansas: U.S. Geological Survey Water-Resources Investigations Report 02-4021, $25 \mathrm{p}$.

Putnam, J.E., and Schneider, D.R., 2004, Water resources data-Kansas, water year 2003: U.S. Geological Survey Water-Data Report KS-03-1, available on Web, accessed November 7, 2005, at http://water.usgs.gov/pubs/wdr/ $w d r-k s-03-01 /$

Rashash, D.M., Hoehn, R.C., Dietrich, A.M., Gizzard, T.J., and Parker, B.C., 1996, Identification and control of odorous algal metabolites: Denver, Colorado, American Water Works Association Research Foundation and American Water Works Association, $172 \mathrm{p}$.

Rasmussen, P.P., and Ziegler, A.C., 2003, Comparison of continuous estimates of fecal coliform and Escherichia coli bacteria in selected Kansas streams, May 1999 through April 2002: U.S. Geological Survey Water-Resources Investigations Report 03-4056, $80 \mathrm{p}$.

Reid, G.K., and Wood, R.D., 1976, Ecology of inland waters and estuaries: New York, D. Van Nostrand Co., 485 p.

Rockers, J.J., Ratcliff, Ivan, Down, L.W., and Bouse, E. F., 1966, Soil survey of Reno County, Kansas: U. S. Department of Agriculture, Soil Conservation Service, $72 \mathrm{p}$.

Saadoun, I.M.K., Schrader, K.K., and Blevins, W.T., 2001, Environmental and nutritional factors affecting geosmin synthesis by Anabaena sp.: Water Research, v. 35, no. 5, p. 1209-1218.

Sadar, Mike, 2002, Turbidity instrumentation—an overview of today's available technology, in Gray, J.R., and Glysson, G.D., eds., Proceedings of the Federal Interagency Workshop on Turbidity and Other Sediment Surrogates, April 30May 2, 2002, Reno, Nevada, appendix 2: Available on Web, accessed May 4, 2005, at http://water.usgs.gov/osw/ techniques/TSS/sadar.pdf

Scott, N., 2002, Algae, cyanobacteria, and water quality: Agriculture and Agri-Food Canada, $4 \mathrm{p}$.

Sedgwick County, 2004, Sedgwick County water supply and wastewater management assessment 2004: 207 p.

Sharpley, A.N., and Rekolainen, S., 1997, Phosphorus in agriculture and its environmental conditions, in Tunney, H., Carton, O.T., Brookes, P.C., and Johnson, A.E., eds., Phospho- rus loss from soil to water: New York, Cab International, p. 1-53.

Smith, V.H., deNoyes, Frank, Jr., Graham, D.W., and Randtke, S.J., 2001, A comparative water quality study of Cheney Reservoir, Kansas-final report to the city of Wichita Water and Sewer Department: Lawrence, University of Kansas, Department of Ecology and Evolutionary Biology, 28 p.

Smith, V.H., Sieber-Denlinger, Jonathan, deNoyes, Frank, Jr., Campbell, Scott, Pan, Shugen, Randke, S.J., Blain, G.T., and Strasser, V.A., 2002, Managing taste and odor problems in a eutrophic drinking water reservoir: Lake and Reservoir Management, v. 18, no. 4, p. 319-323.

Suffet, I.H., Khiari, Djanette, and Bruchet, Auguste, 1999, The drinking water taste and odor wheel for the millenniumbeyond geosmin and 2-methylisoborneal: Water Science and Technology, v. 40, no. 6, p. 1-13.

Sugiura, Norio, Iwami, Norio, Inamori, Yuhei, Nishimura, Osamu, and Sudo, Ryuichi, 1998, Significance of attached cyanobacteria relevant to the occurrence of musty odor in Lake Kasumigaura: Water Resources, v. 32, no. 12, p. 3549-3554.

Tippecanoe Environmental Lake and Watershed Foundation, 2004, Kjeldahl nitrogen: Information available on Web, accessed October 26, 2004, at http://www.telwf.org/ watertesting/kjedahl.htm

U.S. Environmental Protection Agency, 1986, Quality criteria for water, 1986: U.S. Environmental Protection Agency Report 440/5-86-001, unnumbered pages.

U.S. Environmental Protection Agency, 2000, Nutrient criteria technical guidance manual-rivers and streams: U.S. Environmental Protection Agency Report 822/B-00-002, various pagination.

U.S. Environmental Protection Agency, 2001a, Ambient water quality criteria recommendations - rivers and streams in nutrient ecoregion V: U.S. Environmental Protection Agency Report 822-B-01-014, various pagination.

U.S. Environmental Protection Agency, 2001b, Ambient water quality criteria recommendations-lakes and reservoirs in nutrient ecoregion V: U.S. Environmental Protection Agency Report 822-B-01-010, various pagination.

U.S. Environmental Protection Agency, 2002, Drinking water standards and health advisories: U.S. Environmental Protection Agency Report 822-R-02-038, various pagination.

U.S. Fish and Wildlife Service, 1996, Environmental study of Cheney Reservoir-a completion report of tasks performed by the U.S. Fish and Wildlife Service, submitted to Bureau of Reclamation, Austin, Texas, December 1, 1996: p. C1-C24.

Wagner, R.J., Mattraw, H.C., Ritz, G.F., and Smith B.A., 2000, Guidelines and standard procedures for continuous waterquality monitors-site selection, field operation, calibration, record computation, and reporting: U.S. Geological Survey Water-Resources Investigations Report 00-4252, $53 \mathrm{p}$.

Walker, W.W., Jr., Westerberg, C.E., Schuler, D.J., and Bode, J.A., 1989, Design and evaluation of eutrophication control measures for the St. Paul water supply: Lake and Reservoir Management, v. 5, no. 1, p. 71-83. 
Wang, Steven, Huggins, D.G., Lim, N.C., Baker, D.S., Spotts, W.W., Goodrich, C.A., deNoyelles, Frank, Jr., Campbell, S.W., Frees, Lyle, and Volkman, Chad, 2003, Cheney Reservoir water quality and its watershed assessment: Kansas Biological Survey Publication No. 112, 37 p.

Watson, S.B., 2003, Cyanobacterial and eukaryotic algal odour compounds - signals or by-products? A review of their biological activity: Phycologia, v. 42, no. 4, p. 332-350.

Wetzel, R.G., 2001, Limnology-lake and river ecosystems (3d ed.): San Diego, California, Academic Press, 1006 p.

Wu, J., Ma, P.I., and Chou, T.L., 1991, Variation of geosmin content in Anabaena cells and its relation to nitrogen utilization: Archives of Microbiology, v. 157, p. 66-69.

YSI, 2005, In vivo measurement of chlorophyll and the YSI 6025 wiped chlorophyll sensor: Information available on Web, accessed March 8, 2005, at http://www.ysi.com
Zeller, D.E., ed., 1968, The stratigraphic succession in Kansas: Kansas Geological Survey Bulletin 189, 81 p.

Ziegler, A.C., 2003, Issues related to use of turbidity measurements as a surrogate for suspended sediment, in Gray, J.R., and Glysson, G.D., eds., Proceedings of the Federal Interagency Workshop on Turbidity and Other Sediment Surrogates, April 30-May 2, 2002, Reno, Nevada: U.S. Geological Survey Circular 1250, p. 16-18.

Zimmerman, L.R., Ziegler, A.C., and Thurman, E.M., 2002, Method of analysis and quality-assurance practices by U.S. Geological Survey Organic Geochemistry Research Group-determination of geosmin and methylisoborneol in water using solid-phase microextraction and gas chromatography/mass spectrometry: U.S. Geological Survey Open-File Report 02-337, 12 p. 


\section{Supplemental Information}


Table 8. Phytoplankton taxa, biovolume, and percentage of total biovolume, Cheney Reservoir, south-central Kansas, 2001-03.

[ $\mu \mathrm{m}^{3} / \mathrm{mL}$, cubic micrometers per milliliter of water; --, not determined]

\begin{tabular}{|c|c|c|c|}
\hline $\begin{array}{c}\text { Date } \\
\text { (month/day/year) }\end{array}$ & Taxa & $\begin{array}{l}\text { Biovolume } \\
\left(\mu \mathrm{m}^{3} / \mathrm{mL}\right)\end{array}$ & $\begin{array}{l}\text { Percentage of } \\
\text { total biovolume }\end{array}$ \\
\hline \multirow[t]{28}{*}{$6 / 22 / 2001$} & Bacillariophyta & $89,183,800$ & 31.63 \\
\hline & Gyrosigma sp. & $9,920,000$ & -- \\
\hline & Melosira granulata & $26,700,000$ & -- \\
\hline & Rhoicospenia curvata & 63,800 & -- \\
\hline & Stephanodiscus sp. & $52,500,000$ & -- \\
\hline & Chlorophyta & $5,412,700$ & 1.92 \\
\hline & Crucigenia sp. & 777,000 & -- \\
\hline & Pediastrum duplex & $4,620,000$ & -- \\
\hline & Scenedesmus quadricauda & 15,700 & -- \\
\hline & Chrysophyta & 0 & -- \\
\hline & Cryptophyta & $11,286,000$ & 4.00 \\
\hline & Cryptomonas sp. & 486,000 & -- \\
\hline & Rhodomonas lacustris & $10,800,000$ & \\
\hline & Cyanobacteria & $41,956,500$ & 14.88 \\
\hline & Anabaena circinalis & $4,050,000$ & -- \\
\hline & Anabaena flos-aquae & $16,800,000$ & -- \\
\hline & Anabaena limnetica & 118,000 & -- \\
\hline & Anabaena sp. & $13,800,000$ & -- \\
\hline & Aphanocapsa delicatissma & 51,500 & -- \\
\hline & Gomphonema aponina & $1,250,000$ & -- \\
\hline & Microcystis aeruginosa & 127,000 & -- \\
\hline & Oscillatoria limnetica & $5,370,000$ & -- \\
\hline & Oscillatoria sp. & 390,000 & -- \\
\hline & Euglenophyta & $30,780,000$ & 10.91 \\
\hline & Euglena sp. & $27,300,000$ & -- \\
\hline & Phacus sp. & $3,480,000$ & -- \\
\hline & Pyrrhophyta & $103,000,000$ & 36.52 \\
\hline & Ceratium hirundinella & $103,000,000$ & -- \\
\hline \multirow[t]{14}{*}{$8 / 29 / 2001$} & Bacillariophyta & $70,568,000$ & 79.02 \\
\hline & Cyclotella sp. & $70,300,000$ & -- \\
\hline & Synedra ulna & 268,000 & -- \\
\hline & Chlorophyta & $7,641,000$ & 8.56 \\
\hline & Chlamydomonas sp. & $1,150,000$ & -- \\
\hline & Closterium peracerosum & 855,000 & -- \\
\hline & Pandorina morum & 106,000 & -- \\
\hline & Pediastrum duplex & $5,530,000$ & -- \\
\hline & Chrysophyta & 0 & -- \\
\hline & Cryptophyta & $1,550,000$ & 1.74 \\
\hline & Rhodomonas lacustris & $1,550,000$ & -- \\
\hline & Cyanobacteria & $7,259,880$ & 8.13 \\
\hline & Anabaena sp. & 966,000 & -- \\
\hline & Aphanocapsa delicatissima & 737,000 & -- \\
\hline
\end{tabular}


Table 8. Phytoplankton taxa, biovolume, and percentage of total biovolume, Cheney Reservoir, south-central Kansas, 2001-03.-Continued

[ $\mu \mathrm{m}^{3} / \mathrm{mL}$, cubic micrometers per milliliter of water; --, not determined]

\begin{tabular}{|c|c|c|c|}
\hline $\begin{array}{c}\text { Date } \\
\text { (month/day/year) }\end{array}$ & Taxa & $\begin{array}{l}\text { Biovolume } \\
\left(\mu \mathrm{m}^{3} / \mathrm{mL}\right)\end{array}$ & $\begin{array}{l}\text { Percentage of } \\
\text { total biovolume }\end{array}$ \\
\hline \multirow[t]{5}{*}{$8 / 29 / 2001$} & Aphanothece sp. & 6,880 & -- \\
\hline & Planktothrix sp. & $5,550,000$ & -- \\
\hline & Euglenophyta & $2,240,000$ & 2.51 \\
\hline & Euglena sp. & $2,240,000$ & -- \\
\hline & Pyrrhophyta & 0 & -- \\
\hline \multirow[t]{29}{*}{$5 / 15 / 2002$} & Bacillariophyta & $67,924,500$ & 80.57 \\
\hline & Cyclotella sp. & $14,600,000$ & -- \\
\hline & Melosira granulata & $12,200,000$ & -- \\
\hline & Melosira islandica & $1,270,000$ & -- \\
\hline & Nitzschia sp. & 19,000 & -- \\
\hline & Rhoicospenia curvata & $1,390,000$ & -- \\
\hline & Stephanodiscus sp. & $38,400,000$ & -- \\
\hline & Surirella ovata & 45,500 & -- \\
\hline & Chlorophyta & $10,375,600$ & 12.31 \\
\hline & Actinastrum hantzschii & 53,600 & -- \\
\hline & Arthrodesmus sp. & 143,000 & -- \\
\hline & Closterium sp. & 21,000 & -- \\
\hline & Gloeocystis sp. & $2,310,000$ & -- \\
\hline & Gloeocystis vesiculosa & 828,000 & -- \\
\hline & Pediastrum duplex & $1,830,000$ & -- \\
\hline & Sphaerocystis schroeteri & $3,020,000$ & -- \\
\hline & Staurastrum sp. & $2,170,000$ & -- \\
\hline & Chrysophyta & 0 & -- \\
\hline & Cryptophyta & 0 & -- \\
\hline & Cyanobacteria & $1,028,100$ & 1.22 \\
\hline & Anabaena sp. & 218,000 & -- \\
\hline & Anabaena spiroides & 312,000 & -- \\
\hline & Aphanizomenon flos-aquae & 40,100 & -- \\
\hline & Chroococcus dispersus & 171,000 & -- \\
\hline & Chroococcus limneticus & 287,000 & -- \\
\hline & Euglenophyta & $4,050,000$ & 4.80 \\
\hline & Euglena acus & 800,000 & -- \\
\hline & Euglena sp. & $3,250,000$ & -- \\
\hline & Pyrrhophyta & 0 & -- \\
\hline \multirow[t]{7}{*}{$7 / 11 / 2002$} & Bacillariophyta & $16,000,000$ & 79.21 \\
\hline & Cyclotella sp. & $16,000,000$ & -- \\
\hline & Chlorophyta & $1,771,000$ & 8.77 \\
\hline & Actinastrum hantzschii & 571,000 & -- \\
\hline & Chlamydomonas sp. & $1,200,000$ & -- \\
\hline & Chrysophyta & 0 & -- \\
\hline & Cryptophyta & 513,000 & 2.54 \\
\hline
\end{tabular}


Table 8. Phytoplankton taxa, biovolume, and percentage of total biovolume, Cheney Reservoir, south-central Kansas, 2001-03.-Continued

$\left[\mu \mathrm{m}^{3} / \mathrm{mL}\right.$, cubic micrometers per milliliter of water; --, not determined]

\begin{tabular}{|c|c|c|c|}
\hline $\begin{array}{c}\text { Date } \\
\text { (month/day/year) }\end{array}$ & Taxa & $\begin{array}{l}\text { Biovolume } \\
\left(\mu \mathrm{m}^{3} / \mathrm{mL}\right)\end{array}$ & $\begin{array}{l}\text { Percentage of } \\
\text { total biovolume }\end{array}$ \\
\hline \multirow[t]{13}{*}{$7 / 11 / 2002$} & Cryptomonas sp. & 513,000 & -- \\
\hline & Cyanobacteria & $1,945,000$ & 9.63 \\
\hline & Anabaena circinalis & 882,000 & -- \\
\hline & Anabaena flos-aquae & 30,400 & -- \\
\hline & Anabaena sp. & 543,000 & -- \\
\hline & Anabaenopsis sp. & 131,000 & -- \\
\hline & Aphanocapsa delicatissima & 87,500 & -- \\
\hline & Aphanocapsa sp. & 206,000 & -- \\
\hline & Chroococcus dispersus & 57,100 & -- \\
\hline & Merismopedia elegans & 3,840 & -- \\
\hline & Microcystis aeruginosa & 4,160 & -- \\
\hline & Euglenophyta & 0 & -- \\
\hline & Pyrrhophyta & 0 & -- \\
\hline \multirow[t]{18}{*}{$8 / 7 / 2002$} & Bacillariophyta & $36,400,000$ & 63.00 \\
\hline & Cyclotella sp. & $36,400,000$ & -- \\
\hline & Chlorophyta & $14,909,000$ & 25.80 \\
\hline & Ankistrodesmus falcatus & 370,000 & -- \\
\hline & Chlamydomonas sp. & 329,000 & -- \\
\hline & Coelastrum americanum & $1,170,000$ & -- \\
\hline & Cosmarium sp. & $9,200,000$ & -- \\
\hline & Euastrum sp. & $2,680,000$ & -- \\
\hline & Pandorina morum & $1,160,000$ & -- \\
\hline & Chrysophyta & $4,700,000$ & 8.13 \\
\hline & Dinobryon sp. & $4,700,000$ & -- \\
\hline & Cryptophyta & 0 & -- \\
\hline & Cyanobacteria & 581,410 & 1.00 \\
\hline & Aphanocapsa delicatissima & 2,410 & -- \\
\hline & Gomphosphaeria aponina & 579,000 & -- \\
\hline & Euglenophyta & $1,230,000$ & 2.13 \\
\hline & Euglena sp. & $1,230,000$ & -- \\
\hline & Pyrrhophyta & 0 & -- \\
\hline \multirow[t]{11}{*}{$9 / 4 / 2002$} & Bacillariophyta & $65,417,000$ & 79.97 \\
\hline & Achnanthes sp. & 317,000 & -- \\
\hline & Stephanodiscus sp. & $65,100,000$ & -- \\
\hline & Chlorophyta & 988,600 & 1.21 \\
\hline & Chlamydomonas globossa & 38,000 & -- \\
\hline & Cosmarium sp. & 885,000 & -- \\
\hline & Pandorina morum & 65,600 & -- \\
\hline & Chrysophyta & 325,000 & .40 \\
\hline & Mallomonas producta & 43,000 & -- \\
\hline & Synura sp. & 282,000 & -- \\
\hline & Cryptophyta & $9,070,000$ & 11.09 \\
\hline
\end{tabular}


Table 8. Phytoplankton taxa, biovolume, and percentage of total biovolume, Cheney Reservoir, south-central Kansas, 2001-03.-Continued

$\left[\mu \mathrm{m}^{3} / \mathrm{mL}\right.$, cubic micrometers per milliliter of water; --, not determined]

\begin{tabular}{|c|c|c|c|}
\hline $\begin{array}{c}\text { Date } \\
\text { (month/day/year) }\end{array}$ & Taxa & $\begin{array}{l}\text { Biovolume } \\
\left(\mu \mathrm{m}^{3} / \mathrm{mL}\right)\end{array}$ & $\begin{array}{l}\text { Percentage of } \\
\text { total biovolume }\end{array}$ \\
\hline \multirow[t]{11}{*}{$9 / 4 / 2002$} & Cryptomonas ovata & $9,070,000$ & -- \\
\hline & Cyanobacteria & $5,754,800$ & 7.04 \\
\hline & Anabaena circinalis & 756,000 & -- \\
\hline & Anabaena flos-aquae & $1,280,000$ & -- \\
\hline & Anabaena planctonica & $1,230,000$ & -- \\
\hline & Anabaena sp. & $1,930,000$ & -- \\
\hline & Aphanocapsa pulchra & 543,000 & -- \\
\hline & Aphanocapsa sp. & 15,800 & -- \\
\hline & Euglenophyta & 0 & -- \\
\hline & Pyrrhophyta & 246,000 & .30 \\
\hline & Ceratium hirundinella & 246,000 & -- \\
\hline \multirow[t]{30}{*}{$1 / 12 / 2003$} & Bacillariophyta & $420,460,000$ & 73.51 \\
\hline & Caloneis limosa & $1,190,000$ & -- \\
\hline & Cyclotella sp. & $53,600,000$ & -- \\
\hline & Surirella ovata & $1,670,000$ & -- \\
\hline & Synedra sp. & $364,000,000$ & -- \\
\hline & Chlorophyta & $36,099,880$ & 6.31 \\
\hline & Ankistrodesmus falcatus & $1,740,000$ & -- \\
\hline & Coelastrum microsporum & 106,000 & -- \\
\hline & Dictyosphaerium pulchellum & $13,300,000$ & -- \\
\hline & Micractinium sp. & 5,880 & -- \\
\hline & Pandorina morum & $20,300,000$ & -- \\
\hline & Pediastrum simplex & 27,200 & -- \\
\hline & Scenedesmus brasiliensis & 32,800 & -- \\
\hline & Tetraedon spp. & 588,000 & -- \\
\hline & Chrysophyta & 0 & -- \\
\hline & Cryptophyta & $84,600,000$ & 14.79 \\
\hline & Cryptomonas sp. & $14,100,000$ & -- \\
\hline & Rhodomonas minuta & $70,500,000$ & -- \\
\hline & Cyanobacteria & $30,407,600$ & 5.32 \\
\hline & Anabaena sp. & $1,190,000$ & -- \\
\hline & Aphanocapsa delicatissima & 937,000 & -- \\
\hline & Aphanocapsa sp. & $3,440,000$ & -- \\
\hline & Chroococcus minutus & 40,600 & -- \\
\hline & Chroococcus sp. & $2,790,000$ & -- \\
\hline & Gomphosphaeria aponina & $1,900,000$ & -- \\
\hline & Gomphosphaeria lacustris & $10,900,000$ & -- \\
\hline & Merismopedia elegans & $3,660,000$ & -- \\
\hline & Oscillatoria sp. & $5,550,000$ & -- \\
\hline & Euglenophyta & 0 & -- \\
\hline & Pyrrhophyta & 0 & -- \\
\hline $1 / 23 / 2003$ & Bacillariophyta & 785,000 & .59 \\
\hline
\end{tabular}


Table 8. Phytoplankton taxa, biovolume, and percentage of total biovolume, Cheney Reservoir, south-central Kansas, 2001-03.-Continued

$\left[\mu \mathrm{m}^{3} / \mathrm{mL}\right.$, cubic micrometers per milliliter of water; --, not determined]

\begin{tabular}{|c|c|c|c|}
\hline $\begin{array}{c}\text { Date } \\
\text { (month/day/year) }\end{array}$ & Taxa & $\begin{array}{l}\text { Biovolume } \\
\left(\mu \mathrm{m}^{3} / \mathrm{mL}\right)\end{array}$ & $\begin{array}{l}\text { Percentage of } \\
\text { total biovolume }\end{array}$ \\
\hline \multirow[t]{31}{*}{$1 / 23 / 2003$} & Cymbella sp. & 785,000 & -- \\
\hline & Chlorophyta & $74,908,000$ & 56.32 \\
\hline & Actinastrum hantzschii & $2,580,000$ & -- \\
\hline & Coelastrum microsporum & $13,300,000$ & -- \\
\hline & Dictyosphaerium pulchellum & $2,630,000$ & -- \\
\hline & Gonium pectorale & $1,710,000$ & -- \\
\hline & Micractinium pussillum & 10,200 & -- \\
\hline & Pandorina morum & $26,200,000$ & -- \\
\hline & Scenedesmus sp. & 22,400 & -- \\
\hline & Selenastrum minutum & 70,400 & -- \\
\hline & Sphaerocystis schroeteri & $27,500,000$ & -- \\
\hline & Tetraedon spp. & 617,000 & -- \\
\hline & Tetrastrum sp. & 268,000 & -- \\
\hline & Chrysophyta & 46,000 & .03 \\
\hline & Mallomonas sp. & 46,000 & -- \\
\hline & Cryptophyta & $12,500,000$ & 9.40 \\
\hline & Rhodomonas minuta & $12,500,000$ & -- \\
\hline & Cyanobacteria & $44,859,500$ & 33.73 \\
\hline & Anabaena sp. & $1,170,000$ & -- \\
\hline & Aphanocapsa delicatissima & $2,800,000$ & -- \\
\hline & Aphanocapsa sp. & $3,290,000$ & -- \\
\hline & Aphanothece sp. & $4,720,000$ & -- \\
\hline & Aphanothece stagnina & 18,200 & -- \\
\hline & Cylindrospermopsis sp. & $11,200,000$ & -- \\
\hline & Gomphosphaeria aponina & 67,800 & -- \\
\hline & Merismopedia elegans & 65,500 & -- \\
\hline & Oscillatoria sp. & $18,900,000$ & -- \\
\hline & Pseudanabaena spp. & 168,000 & -- \\
\hline & Synechococcus sp. & $2,460,000$ & -- \\
\hline & Euglenophyta & 0 & -- \\
\hline & Pyrrhophyta & 0 & -- \\
\hline \multirow[t]{12}{*}{$2 / 10 / 2003$} & Bacillariophyta & $130,607,000$ & 65.63 \\
\hline & Cocconeis placentula & 83,000 & -- \\
\hline & Cyclotella sp. & $126,000,000$ & -- \\
\hline & Navicula sp. & 514,000 & -- \\
\hline & Surirella ovata & $1,710,000$ & -- \\
\hline & Synedra sp. & $2,300,000$ & -- \\
\hline & Chlorophyta & $23,954,000$ & 12.04 \\
\hline & Actinastrum hantzschii & $2,700,000$ & -- \\
\hline & Ankistrodesmus falcatus & $2,340,000$ & -- \\
\hline & Closteriopsis sp. & 49,000 & -- \\
\hline & Elakatothrix gelatinosa & $1,420,000$ & -- \\
\hline & Gonium pectorale & $2,440,000$ & -- \\
\hline
\end{tabular}


Table 8. Phytoplankton taxa, biovolume, and percentage of total biovolume, Cheney Reservoir, south-central Kansas, 2001-03.-Continued

$\left[\mu \mathrm{m}^{3} / \mathrm{mL}\right.$, cubic micrometers per milliliter of water; --, not determined]

\begin{tabular}{|c|c|c|c|}
\hline $\begin{array}{c}\text { Date } \\
\text { (month/day/year) }\end{array}$ & Taxa & $\begin{array}{l}\text { Biovolume } \\
\left(\mu \mathrm{m}^{3} / \mathrm{mL}\right)\end{array}$ & $\begin{array}{l}\text { Percentage of } \\
\text { total biovolume }\end{array}$ \\
\hline \multirow[t]{22}{*}{$2 / 10 / 2003$} & Pandorina morum & $8,020,000$ & -- \\
\hline & Scenedesmus quadricauda & 688,000 & -- \\
\hline & Selenastrum minutum & $1,930,000$ & -- \\
\hline & Staurastrum sp. & $3,040,000$ & -- \\
\hline & Tetraedon spp. & 961,000 & -- \\
\hline & Tetrastrum sp. & 366,000 & -- \\
\hline & Chrysophyta & $2,720,000$ & 1.37 \\
\hline & Mallomonas sp. & $2,720,000$ & -- \\
\hline & Cryptophyta & $30,927,600$ & 15.54 \\
\hline & Cryptomonas sp. & $30,900,000$ & -- \\
\hline & Rhodomonas lacustris & 27,600 & -- \\
\hline & Cyanobacteria & $7,424,500$ & 3.73 \\
\hline & Anabaena sp. & 82,500 & -- \\
\hline & Aphanocapsa delicatissima & 270,000 & -- \\
\hline & Aphanocapsa sp. & $1,050,000$ & -- \\
\hline & Chroococcus minutus & 280,000 & -- \\
\hline & Merismopedia tenuissima & 592,000 & -- \\
\hline & Oscillatoria anguina & $3,990,000$ & -- \\
\hline & Synechococcus sp. & $1,160,000$ & -- \\
\hline & Euglenophyta & $3,630,000$ & 1.82 \\
\hline & Trachelomonas spp. & $3,630,000$ & -- \\
\hline & Pyrrhophyta & 0 & -- \\
\hline \multirow[t]{21}{*}{$3 / 3 / 2003$} & Bacillariophyta & $40,944,000$ & 28.43 \\
\hline & Cyclotella sp. & $40,800,000$ & -- \\
\hline & Surirella ovata & 144,000 & -- \\
\hline & Chlorophyta & $8,810,000$ & 6.12 \\
\hline & Ankistrodesmus falcatus & $3,070,000$ & -- \\
\hline & Eudorina elegans & $1,330,000$ & \\
\hline & Pandorina morum & $4,410,000$ & \\
\hline & Chrysophyta & 0 & -- \\
\hline & Cryptophyta & $82,200,000$ & 57.08 \\
\hline & Rhodomonas minuta & $82,200,000$ & -- \\
\hline & Cyanobacteria & $7,589,660$ & 5.27 \\
\hline & Anabaena sp. & 48,300 & -- \\
\hline & Aphanocapsa delicatissima & 397,000 & -- \\
\hline & Aphanocapsa sp. & $1,420,000$ & -- \\
\hline & Aphanothece sp. & $1,880,000$ & -- \\
\hline & Chroococcus limneticus & 793,000 & -- \\
\hline & Chroococcus minutus & 172,000 & -- \\
\hline & Merismopedia spp. & 204,000 & -- \\
\hline & Merismopedia tenuissima & 670,000 & -- \\
\hline & Oscillatoria anguina & 137,000 & -- \\
\hline & Pseudanabaena spp. & 8,360 & -- \\
\hline
\end{tabular}


Table 8. Phytoplankton taxa, biovolume, and percentage of total biovolume, Cheney Reservoir, south-central Kansas, 2001-03.-Continued

$\left[\mu \mathrm{m}^{3} / \mathrm{mL}\right.$, cubic micrometers per milliliter of water; --, not determined]

\begin{tabular}{|c|c|c|c|}
\hline $\begin{array}{c}\text { Date } \\
\text { (month/day/year) }\end{array}$ & Taxa & $\begin{array}{c}\text { Biovolume } \\
\left(\mu \mathrm{m}^{3} / \mathrm{mL}\right)\end{array}$ & $\begin{array}{l}\text { Percentage of } \\
\text { total biovolume }\end{array}$ \\
\hline \multirow[t]{4}{*}{$3 / 3 / 2003$} & Synechococcus sp. & $1,860,000$ & -- \\
\hline & Euglenophyta & $4,250,000$ & 2.95 \\
\hline & Trachelomonas spp. & $4,250,000$ & -- \\
\hline & Pyrrhophyta & 0 & -- \\
\hline \multirow[t]{28}{*}{$3 / 12 / 2003$} & Bacillariophyta & $79,100,000$ & 27.56 \\
\hline & Cyclotella sp. & $79,100,000$ & -- \\
\hline & Chlorophyta & $36,352,600$ & 12.67 \\
\hline & Ankistrodesmus falcatus & 476,000 & -- \\
\hline & Ankistrodesmus mirabilis & 188,000 & -- \\
\hline & Chlamydomonas sp. & $22,300,000$ & -- \\
\hline & Dictyosphaerium smithii & $3,330,000$ & -- \\
\hline & Gonium pectorale & $3,700,000$ & -- \\
\hline & Monoraphidium capricomutum & 51,600 & -- \\
\hline & Pandorina morum & $2,080,000$ & -- \\
\hline & Selenastrum westii & 158,000 & -- \\
\hline & Staurastrum sp. & $2,660,000$ & -- \\
\hline & Tetraedon spp. & 497,000 & -- \\
\hline & Tetrastrum staurogeniaeforme & 912,000 & -- \\
\hline & Chrysophyta & 0 & -- \\
\hline & Cryptophyta & $153,110,000$ & 53.35 \\
\hline & Cryptomonas sp. & $1,110,000$ & -- \\
\hline & Rhodomonas minuta & $152,000,000$ & \\
\hline & Cyanobacteria & $16,806,400$ & 5.86 \\
\hline & Anabaena planctonica & $1,000,000$ & -- \\
\hline & Anabaena sp. & $9,560,000$ & -- \\
\hline & Gomphosphaeria sp. & $1,140,000$ & -- \\
\hline & Oscillatoria anguina & 56,400 & -- \\
\hline & Oscillatoria sp. & $2,400,000$ & -- \\
\hline & Synechococcus sp. & $2,650,000$ & -- \\
\hline & Euglenophyta & $1,760,000$ & .61 \\
\hline & Trachelomonas spp. & $1,760,000$ & -- \\
\hline & Pyrrhophyta & 0 & -- \\
\hline \multirow[t]{10}{*}{$3 / 12 / 2003$} & Bacillariophyta & $37,929,000$ & 13.64 \\
\hline & Caloneis limosa & 125,000 & -- \\
\hline & Cyclotella sp. & $35,800,000$ & -- \\
\hline & Nitzschia sp. & 35,000 & -- \\
\hline & Surirella sp. & $1,940,000$ & -- \\
\hline & Synedra sp. & 29,000 & -- \\
\hline & Chlorophyta & $48,706,400$ & 17.52 \\
\hline & Ankistrodesmus falcatus & 644,000 & -- \\
\hline & Chlamydomonas sp. & $27,200,000$ & -- \\
\hline & Coelastrum reticulatum & 149,000 & -- \\
\hline
\end{tabular}


Table 8. Phytoplankton taxa, biovolume, and percentage of total biovolume, Cheney Reservoir, south-central Kansas, 2001-03.-Continued

$\left[\mu \mathrm{m}^{3} / \mathrm{mL}\right.$, cubic micrometers per milliliter of water; --, not determined]

\begin{tabular}{|c|c|c|c|}
\hline $\begin{array}{c}\text { Date } \\
\text { (month/day/year) }\end{array}$ & Taxa & $\begin{array}{l}\text { Biovolume } \\
\left(\mu \mathrm{m}^{3} / \mathrm{mL}\right)\end{array}$ & $\begin{array}{l}\text { Percentage of } \\
\text { total biovolume }\end{array}$ \\
\hline \multirow[t]{22}{*}{$3 / 12 / 2003$} & Crucigenia apiculata & 69,600 & -- \\
\hline & Dictyosphaerium smithii & $4,440,000$ & -- \\
\hline & Elakatothrix gelatinosa & $3,920,000$ & -- \\
\hline & Elakatothrix sp. & 31,800 & -- \\
\hline & Gonium pectorale & $2,380,000$ & -- \\
\hline & Pandorina morum & $9,520,000$ & -- \\
\hline & Selenastrum westii & 169,000 & -- \\
\hline & Staurastrum sp. & 183,000 & -- \\
\hline & Chrysophyta & 0 & -- \\
\hline & Cryptophyta & $189,060,000$ & 68.01 \\
\hline & Cryptomonas sp. & $2,060,000$ & -- \\
\hline & Rhodomonas minuta & $187,000,000$ & -- \\
\hline & Cyanobacteria & $1,958,400$ & .70 \\
\hline & Anabaena planctonica & 810,000 & -- \\
\hline & Anabaena sp. & 119,000 & -- \\
\hline & Coelosphaerium sp. & 74,400 & -- \\
\hline & Gomphosphaeria aponina & 124,000 & -- \\
\hline & Oscillatoria sp. & 220,000 & -- \\
\hline & Synechococcus sp. & 611,000 & -- \\
\hline & Euglenophyta & 0 & -- \\
\hline & Pyrrhophyta & 112,000 & .04 \\
\hline & Peridinium sp. & 112,000 & -- \\
\hline \multirow[t]{21}{*}{$3 / 13 / 2003$} & Bacillariophyta & $43,754,000$ & 26.04 \\
\hline & Cyclotella sp. & $36,700,000$ & -- \\
\hline & Fragilaria crotonensis & 244,000 & -- \\
\hline & Synedra delicatissima & $4,910,000$ & -- \\
\hline & Synedra sp. & $1,900,000$ & -- \\
\hline & Chlorophyta & $18,400,000$ & 10.95 \\
\hline & Eudorina elegans & $3,000,000$ & -- \\
\hline & Pandorina morum & $15,400,000$ & -- \\
\hline & Chrysophyta & 0 & -- \\
\hline & Cryptophyta & $73,100,000$ & 43.51 \\
\hline & Rhodomonas minuta & $73,100,000$ & -- \\
\hline & Cyanobacteria & $15,748,500$ & 9.37 \\
\hline & Anabaena sp. & $2,730,000$ & -- \\
\hline & Aphanocapsa sp. & 317,000 & -- \\
\hline & Aphanothece sp. & 380,000 & -- \\
\hline & Gomphosphaeria lacustris & $2,640,000$ & -- \\
\hline & Merismopedia tenuissima & 192,000 & -- \\
\hline & Microcystis aeruginosa & 2,500 & -- \\
\hline & Oscillatoria anguina & $2,190,000$ & -- \\
\hline & Oscillatoria $s p$ & $7,130,000$ & -- \\
\hline & Pseudanabaena spp. & 167,000 & -- \\
\hline
\end{tabular}


Table 8. Phytoplankton taxa, biovolume, and percentage of total biovolume, Cheney Reservoir, south-central Kansas, 2001-03.-Continued

$\left[\mu \mathrm{m}^{3} / \mathrm{mL}\right.$, cubic micrometers per milliliter of water; --, not determined]

\begin{tabular}{|c|c|c|c|}
\hline $\begin{array}{c}\text { Date } \\
\text { (month/day/year) }\end{array}$ & Taxa & $\begin{array}{c}\text { Biovolume } \\
\left(\mu \mathrm{m}^{3} / \mathrm{mL}\right)\end{array}$ & $\begin{array}{l}\text { Percentage of } \\
\text { total biovolume }\end{array}$ \\
\hline \multirow[t]{3}{*}{$3 / 13 / 2003$} & Euglenophyta & $16,500,000$ & 9.82 \\
\hline & Trachelomonas spp. & $16,500,000$ & -- \\
\hline & Pyrrhophyta & 0 & -- \\
\hline \multirow[t]{27}{*}{$3 / 13 / 2003$} & Bacillariophyta & $54,003,200$ & 25.47 \\
\hline & Cyclotella sp. & $45,400,000$ & -- \\
\hline & Cymbella sp. & 43,200 & -- \\
\hline & Synedra delicatissima & $5,490,000$ & -- \\
\hline & Synedra sp. & $3,070,000$ & -- \\
\hline & Chlorophyta & $16,402,400$ & 7.74 \\
\hline & Actinastrum hantzschii & $9,810,000$ & -- \\
\hline & Ankistrodesmus falcatus & $1,420,000$ & -- \\
\hline & Closterium sp. & 40,000 & -- \\
\hline & Pandorina morum & $4,010,000$ & -- \\
\hline & Pediastrum simplex & 31,400 & -- \\
\hline & Tetraedon spp. & 628,000 & -- \\
\hline & Tetrastrum sp. & 463,000 & -- \\
\hline & Chrysophyta & 0 & -- \\
\hline & Cryptophyta & $103,000,000$ & 48.58 \\
\hline & Rhodomonas minuta & $103,000,000$ & -- \\
\hline & Cyanobacteria & $19,688,600$ & 9.29 \\
\hline & Anabaena sp. & $2,040,000$ & -- \\
\hline & Aphanocapsa sp. & 480,000 & -- \\
\hline & Aphanothece sp. & 119,000 & -- \\
\hline & Merismopedia tenuissima & 9,600 & -- \\
\hline & Oscillatoria sp. & $5,450,000$ & -- \\
\hline & Oscillatoria tenuis & $10,200,000$ & -- \\
\hline & Synechococcus sp. & $1,390,000$ & -- \\
\hline & Euglenophyta & $18,600,000$ & 8.77 \\
\hline & Trachelomonas spp. & $18,600,000$ & -- \\
\hline & Pyrrhophyta & 0 & -- \\
\hline \multirow[t]{12}{*}{$3 / 14 / 2003$} & Bacillariophyta & $50,280,000$ & 39.59 \\
\hline & Cyclotella sp. & $41,400,000$ & -- \\
\hline & Surirella sp. & $1,510,000$ & -- \\
\hline & Synedra delicatissima & $5,550,000$ & -- \\
\hline & Synedra sp. & $1,820,000$ & -- \\
\hline & Chlorophyta & $4,788,500$ & 3.77 \\
\hline & Ankistrodesmus falcatus & $2,320,000$ & -- \\
\hline & Elakatothrix gelatinosa & $1,620,000$ & -- \\
\hline & Gonium pectorale & 97,200 & -- \\
\hline & Micractinium sp. & 722,000 & -- \\
\hline & Pediastrum simplex & 29,300 & -- \\
\hline & Chrysophyta & 0 & -- \\
\hline
\end{tabular}


Table 8. Phytoplankton taxa, biovolume, and percentage of total biovolume, Cheney Reservoir, south-central Kansas, 2001-03.-Continued

$\left[\mu \mathrm{m}^{3} / \mathrm{mL}\right.$, cubic micrometers per milliliter of water; --, not determined]

\begin{tabular}{|c|c|c|c|}
\hline $\begin{array}{c}\text { Date } \\
\text { (month/day/year) }\end{array}$ & Taxa & $\begin{array}{l}\text { Biovolume } \\
\left(\mu \mathrm{m}^{3} / \mathrm{mL}\right)\end{array}$ & $\begin{array}{l}\text { Percentage of } \\
\text { total biovolume }\end{array}$ \\
\hline \multirow[t]{11}{*}{$3 / 14 / 2003$} & Cryptophyta & $64,500,000$ & 50.79 \\
\hline & Rhodomonas minuta & $64,500,000$ & -- \\
\hline & Cyanobacteria & $4,091,000$ & 3.22 \\
\hline & Aphanocapsa delicatissima & 381,000 & -- \\
\hline & Aphanocapsa sp. & $1,370,000$ & -- \\
\hline & Aphanothece sp. & 160,000 & -- \\
\hline & Chroococcus minutus & 280,000 & -- \\
\hline & Synechococcus sp. & $1,900,000$ & -- \\
\hline & Euglenophyta & $3,350,000$ & 2.64 \\
\hline & Trachelomonas spp. & $3,350,000$ & -- \\
\hline & Pyrrhophyta & 0 & -- \\
\hline \multirow[t]{22}{*}{$6 / 17 / 2003$} & Bacillariophyta & $55,528,000$ & 20.12 \\
\hline & Asterionella formossa & $51,200,000$ & -- \\
\hline & Cyclotella sp. & $3,740,000$ & -- \\
\hline & Synedra ulna & 588,000 & -- \\
\hline & Chlorophyta & $1,520,000$ & .55 \\
\hline & Chlamydomonas sp. & $1,520,000$ & -- \\
\hline & Chrysophyta & 0 & -- \\
\hline & Cryptophyta & 0 & -- \\
\hline & Cyanobacteria & $215,376,900$ & 78.04 \\
\hline & Anabaena circinalis & $6,740,000$ & -- \\
\hline & Anabaena flos-aquae & $42,000,000$ & -- \\
\hline & Anabaena spiroides & $5,230,000$ & -- \\
\hline & Anabaenopsis sp. & $1,640,000$ & -- \\
\hline & Aphanizomenon flos-aquae & $159,000,000$ & -- \\
\hline & Aphanothece sp. & 23,500 & -- \\
\hline & Coelosphaerium kuetzingianum & 86,600 & -- \\
\hline & Gomphosphaeria lacustris & 87,100 & -- \\
\hline & Microcystis aeruginosa & 558,000 & -- \\
\hline & Microcystis sp. & 11,700 & -- \\
\hline & Euglenophyta & 0 & -- \\
\hline & Pyrrhophyta & $3,780,000$ & 1.37 \\
\hline & Ceratium hirundinella & $3,780,000$ & -- \\
\hline \multirow[t]{9}{*}{$6 / 20 / 2003$} & Bacillariophyta & $8,971,400$ & 23.24 \\
\hline & Asterionella formossa & $7,200,000$ & -- \\
\hline & Aulacoseira sp. & 73,400 & -- \\
\hline & Cyclotella sp. & 688,000 & -- \\
\hline & Rhoicospenia curvata & $1,010,000$ & -- \\
\hline & Chlorophyta & 150,400 & .39 \\
\hline & Chlamydomonas sp. & 93,500 & -- \\
\hline & Pandorina morum & 56,900 & -- \\
\hline & Chrysophyta & 0 & -- \\
\hline
\end{tabular}


Table 8. Phytoplankton taxa, biovolume, and percentage of total biovolume, Cheney Reservoir, south-central Kansas, 2001-03.-Continued

[ $\mu \mathrm{m}^{3} / \mathrm{mL}$, cubic micrometers per milliliter of water; --, not determined]

\begin{tabular}{|c|c|c|c|}
\hline $\begin{array}{c}\text { Date } \\
\text { (month/day/year) }\end{array}$ & Taxa & $\begin{array}{l}\text { Biovolume } \\
\left(\mu \mathrm{m}^{3} / \mathrm{mL}\right)\end{array}$ & $\begin{array}{l}\text { Percentage of } \\
\text { total biovolume }\end{array}$ \\
\hline \multirow[t]{15}{*}{$6 / 20 / 2003$} & Cryptophyta & 0 & -- \\
\hline & Cyanobacteria & $22,152,780$ & 57.39 \\
\hline & Anabaena circinalis & 313,000 & -- \\
\hline & Anabaena flos-aquae & 113,000 & -- \\
\hline & Anabaena sp. & $3,320,000$ & -- \\
\hline & Anabaenopsis sp. & 40,000 & -- \\
\hline & Aphanizomenon flos-aquae & $18,300,000$ & -- \\
\hline & Aphanothece sp. & 7,100 & -- \\
\hline & Chroococcus minutus & 46,800 & -- \\
\hline & Merismopedia elegans & 7,360 & -- \\
\hline & Merismopedia spp. & 4,800 & -- \\
\hline & Microcystis aeruginosa & 720 & -- \\
\hline & Euglenophyta & 0 & -- \\
\hline & Pyrrhophyta & $7,290,000$ & 18.89 \\
\hline & Ceratium hirundinella & $7,290,000$ & -- \\
\hline \multirow[t]{19}{*}{$7 / 7 / 2003$} & Bacillariophyta & $1,182,260,000$ & 98.52 \\
\hline & Aulacoseira granulata & $1,140,000,000$ & -- \\
\hline & Aulacoseira islandica & $18,100,000$ & -- \\
\hline & Cyclotella sp. & $19,800,000$ & -- \\
\hline & Rhoicospenia curvata & $4,360,000$ & -- \\
\hline & Chlorophyta & & \\
\hline & Chrysophyta & 0 & -- \\
\hline & Cryptophyta & 0 & -- \\
\hline & Cyanobacteria & $12,808,000$ & 1.07 \\
\hline & Anabaena circinalis & 330,000 & -- \\
\hline & Anabaena flos-aquae & $9,290,000$ & -- \\
\hline & Anabaenopsis sp. & 34,700 & -- \\
\hline & Aphanizomenon sp. & 29,600 & -- \\
\hline & Aphanocapsa sp. & $2,810,000$ & -- \\
\hline & Coelosphaerium kuetzingianum & 58,100 & -- \\
\hline & Microcystis aeruginosa & 215,000 & -- \\
\hline & Microcystis sp. & 40,600 & -- \\
\hline & Euglenophyta & 0 & -- \\
\hline & Pyrrhophyta & 0 & -- \\
\hline \multirow[t]{8}{*}{$7 / 17 / 2003$} & Bacillariophyta & $386,024,800$ & 69.68 \\
\hline & Aulacoseira granulata & $370,000,000$ & -- \\
\hline & Aulacoseira islandica & $11,900,000$ & -- \\
\hline & Cyclotella sp. & $1,250,000$ & -- \\
\hline & Fragilaria $s p$ & 64,800 & -- \\
\hline & Stephanodiscus hantzschii & $2,810,000$ & -- \\
\hline & Chlorophyta & & \\
\hline & Chrysophyta & 0 & -- \\
\hline
\end{tabular}


Table 8. Phytoplankton taxa, biovolume, and percentage of total biovolume, Cheney Reservoir, south-central Kansas, 2001-03.-Continued

$\left[\mu \mathrm{m}^{3} / \mathrm{mL}\right.$, cubic micrometers per milliliter of water; --, not determined]

\begin{tabular}{|c|c|c|c|}
\hline $\begin{array}{c}\text { Date } \\
\text { (month/day/year) }\end{array}$ & Taxa & $\begin{array}{l}\text { Biovolume } \\
\left(\mu \mathrm{m}^{3} / \mathrm{mL}\right)\end{array}$ & $\begin{array}{l}\text { Percentage of } \\
\text { total biovolume }\end{array}$ \\
\hline \multirow[t]{10}{*}{$7 / 17 / 2003$} & Cryptophyta & 0 & -- \\
\hline & Cyanobacteria & $161,760,000$ & 29.20 \\
\hline & Anabaena circinalis & $9,160,000$ & -- \\
\hline & Anabaena sp. & $4,600,000$ & -- \\
\hline & Anabaenopsis sp. & $148,000,000$ & -- \\
\hline & Euglenophyta & $1,560,000$ & .28 \\
\hline & Euglena sp. & $1,560,000$ & -- \\
\hline & Pyrrhophyta & $4,434,000$ & .80 \\
\hline & Ceratium hirundinella & 304,000 & -- \\
\hline & Glenodinium sp. & $4,130,000$ & -- \\
\hline \multirow[t]{19}{*}{$7 / 28 / 2003$} & Bacillariophyta & $197,480,000$ & 52.38 \\
\hline & Aulacoseira granulata & $170,000,000$ & -- \\
\hline & Aulacoseira sp. & $16,900,000$ & -- \\
\hline & Cyclotella sp. & $1,740,000$ & -- \\
\hline & Stephanodiscus sp. & $8,840,000$ & -- \\
\hline & Chlorophyta & 514,000 & .14 \\
\hline & Closteriopsis sp. & 514,000 & -- \\
\hline & Chrysophyta & 0 & -- \\
\hline & Cryptophyta & 0 & -- \\
\hline & Cyanobacteria & $160,836,200$ & 42.66 \\
\hline & Anabaena circinalis & $15,100,000$ & -- \\
\hline & Anabaena sp. & $22,700,000$ & -- \\
\hline & Anabaenopsis sp. & $123,000,000$ & -- \\
\hline & Aphanocapsa sp. & 32,800 & -- \\
\hline & Microcystis flos-aquae & 3,400 & -- \\
\hline & Euglenophyta & $1,210,000$ & .32 \\
\hline & Trachelomonas spp. & $1,210,000$ & -- \\
\hline & Pyrrhophyta & $16,900,000$ & 4.48 \\
\hline & Ceratium hirundinella & $16,900,000$ & -- \\
\hline
\end{tabular}

